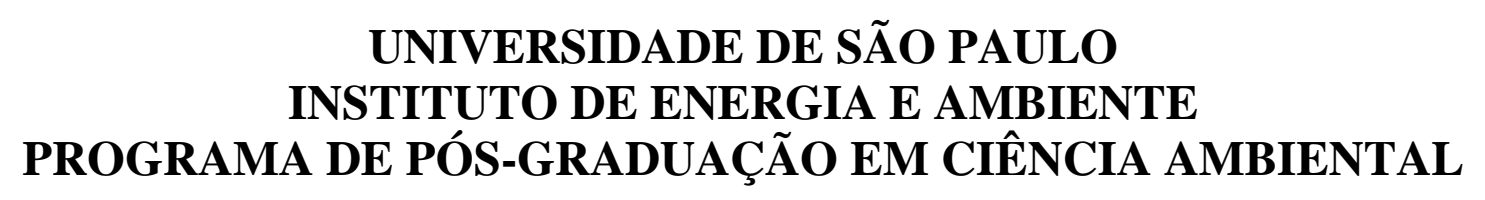

NATÁLIA GIRÃO RODRIGUES DE MELLO

ANÁLISE DOS FATORES RESPONSÁVEIS PELA REDUÇÃO DE DESMATAMENTO NA AMAZÔNIA LEGAL ENTRE OS ANOS DE 2005 E 2013

SÃO PAULO

2016 


\section{ANÁLISE DOS FATORES RESPONSÁVEIS PELA REDUÇÃO DE DESMATAMENTO NA AMAZÔNIA LEGAL ENTRE OS ANOS DE 2005 E 2013}

Dissertação apresentada ao Programa de Pós-Graduação em Ciência Ambiental (PROCAM) do Instituto de Energia e Ambiente da Universidade de São Paulo para a obtenção do título de Mestre em Ciência Ambiental.

Orientador: Prof. Dr. Paulo Artaxo Eduardo Netto.

Versão Corrigida

\section{SÃO PAULO}




\section{AUTORIZO A REPRODUÇÃO E DIVULGAÇÃO TOTAL OU PARCIAL DESTE TRABALHO, POR QUALQUER MEIO CONVENCIONAL OU ELETRÔNICO, PARA FINS DE ESTUDO E PESQUISA, DESDE QUE CITADA A FONTE}

\section{FICHA CATALOGRÁFICA}

Mello, Natália Girão Rodrigues de

Análise dos Fatores Responsáveis pela Redução de Desmatamento na Amazônia Legal entre os anos de 2005 e 2013. / Natália Girão Rodrigues de Mello; orientador Paulo Artaxo Eduardo Netto - São Paulo, 2016.

$121 \mathrm{p}$.

Dissertação (Mestrado em Ciência Ambiental) - Programa de Pós-Graduação em Ciência Ambiental - Instituto de Energia e Ambiente da Universidade de São Paulo.

1. Amazônia. 2. Mudanças de Usos do Solo. 3. Desmatamento. 


\section{FOLHA DE APROVAÇÃO}

Nome: MELLO, Natália Girão Rodrigues de

Título: Análise dos Fatores Responsáveis pela Redução de Desmatamento na Amazônia Legal entre os anos de 2005 e 2013.

Dissertação apresentada ao Programa de Pós-Graduação em Ciência Ambiental (PROCAM) do Instituto de Energia e Ambiente da Universidade de São Paulo para a obtenção do título de Mestre em Ciência Ambiental.

Aprovado em: 19/01/2016

Banca Examinadora:

Prof. Dr.: Instituição:

Julgamento: Assinatura:

Prof. Dr.: Instituição:

Julgamento: Assinatura:

Prof. Dr.: Instituição:

Julgamento: Assinatura: 


\section{RESUMO}

MELlO, Natália Girão Rodrigues de. Análise dos Fatores Responsáveis pela Redução de Desmatamento na Amazônia Legal entre os anos de 2005 e 2013. 2015, 121 p. Dissertação (Mestrado em Ciência Ambiental). Pós-Graduação em Ciência Ambiental - Instituto de Energia e Ambiente da Universidade de São Paulo, São Paulo, 2016.

Em um cenário de mudanças climáticas globais, o Brasil enfrenta o desafio de alcançar o desenvolvimento econômico dentro de padrões de baixas emissões de Gases de Efeito Estufa (GEE). Neste sentido, a redução e manutenção de baixas taxas de desmatamento são fundamentais, já que as mudanças de uso do solo configuram-se como fonte expressiva de emissões de GEE do Brasil. Um importante passo para que isso seja alcançado é o entendimento dos fatores que levaram à significativa redução da taxa de desmatamento na Amazônia Legal, observada entre 2005 e 2013. As complexas dinâmicas de uso do solo em tal região são não lineares, e são diferenciadas temporal e espacialmente. Atualmente, os 5 maiores vetores de desmatamento na Amazônia Legal são a produção de soja, a criação de gado, a exploração madeireira, a expansão de obras de infraestrutura e a especulação fundiária. $\mathrm{O}$ presente estudo analisou os fatores responsáveis pela diminuição das taxas de desmatamento observada na região entre 2005 e 2013. A metodologia utilizada para o desenvolvimento do estudo foi a coleta e análise de dados primários (realização de entrevistas) e dados secundários (revisão de literatura e compilação de dados estatísticos existentes). A partir da análise do material coletado, concluiu-se que a redução do desmatamento no período analisado ocorreu através de uma sinergia de fatores políticos, econômicos e culturais. Os fatores basais para tal redução foram: (i) a ausência de incentivos para desmatar grandes áreas devido a baixos preços de commodities de soja e carne de boi e taxas cambiais desfavoráveis entre 2005 e 2007; (ii) a promulgação do Decreto 6321/07 e da Resolução 3545/08 do Banco Central, quando do aumento dos preços das commodities de soja e carne de boi; (iii) a criação e expansão de áreas protegidas no âmbito do PPCDAm; e (iv) o aprimoramento do monitoramento e das medidas de fiscalização na região a partir da utilização de dados gerados pelo Sistema DETER, também no âmbito do PPCDAm. Como fatores secundários para a redução de desmatamento citam-se os elementos de mercado e cultural, com a instituição das Moratórias da Carne e da Soja. Em anos anomalamente secos, não foi verificado aumento de desmatamento, mas em anos secos o aumento do número de focos de incêndios florestais é significativo. $\mathrm{O}$ combate à ilegalidade no setor madeireiro e aos incêndios florestais, a longo prazo, deve ser aprimorado. A sinergia que levou à redução das taxas de desmatamento pode vir a se exaurir devido a diversas pressões, como aumento na demanda por commodities e obras de infraestrutura como rodovias, hidrovias e portos; fragilidade da implementação da legislação ambiental; desenvolvimento de novas atividades econômicas, como produção de óleo de palma; fragilidade das salvaguardas ambientais dos projetos de desenvolvimento da região; e a ausência de políticas socioambientais voltadas aos assentamentos de reforma agrária. Assim, recomenda-se que sejam fortalecidos os mecanismos já existentes de combate ao desmatamento e à degradação florestal e que novos mecanismos sejam criados para que se alcance a manutenção de baixas taxas de desmatamento na Amazônia Legal.

Palavras-chave: Amazônia; Mudanças de Usos do Solo; Desmatamento. 


\begin{abstract}
MELLO, Natália Girão Rodrigues de. Analysis of the Drivers that Led to the Decline in Deforestation Rates in the Brazilian Amazon from 2005 to 2013. 2016, 121 p. Master Thesis. Graduate Program of Environmental Science, Universidade de São Paulo, São Paulo, 2015.
\end{abstract}

Land use dynamics in the Brazilian Amazon are complex, non-linear and temporally and spatially dissimilar. Divergences arise from the debate concerning which factors led to the recent decline in deforestation in the region. Hence, the present study aimed to shed light on the synergy that led to the reduction of deforestation rates in the Brazilian Amazon from 2005 to 2013. The methodology employed consisted of collecting and analysing primary data (interviews) and secondary data (literature review and compilation of existing statistical data). The results indicate that the basal factors for the decline in deforestation were: (i) the absence of incentives for deforesting large areas due to low beef and soy commodities prices from 2005 to 2007; (ii) the promulgation of the Decree 6321/07 and of the Central Bank Resolution 3545/08; (iii) the creation and expansion of existing protected areas; and (iv) the improvement of monitoring and surveillance practices in the region through the use of data generated by the Detection of Deforestation in Real Time (DETER) system. The secondary factors were market-oriented and cultural elements, associated with the launch of the Soy Moratorium, the Beef Moratorium and the embargo of farms were illegal deforestation was detected. Climate variables have not exerted influences in deforestation rates, but in anomalously dry years forest fire numbers increase significantly. The synergy that resulted in lower deforestation rates might be exhausted in future scenarios by a myriad of elements, such as the increased demand for commodities; the paving of new roads and construction of ports; the fragility of the implementation of environmental legislations; the development of new economic activities in the region; and the absence of socioenvironmental politics aimed at land reform settlements. Thus, it is recommended that the existing successful mechanisms to fight deforestation are improved, and new ones are created so that it is possible to maintain low deforestation rates in the Brazilian Amazon.

Keywords: Brazilian Amazon; Land Use Change; Deforestation. 


\section{LISTA DE FIGURAS}

Figura 1: As complexas interações entre clima, uso do solo, fogo, hidrologia, ecologia e dimensões humanas na Amazônia.

Figura 2: Características da cobertura vegetal em diferentes estágios de perturbação florestal.

Figura 3: Vetores de desmatamento na Amazônia Legal....................................................... 7

Figura 4: Evolução da produção mundial de soja e carne (de porco e frango), projetada até o ano de 2020 .

Figura 5: Ilustração da degradação progressiva que resulta em desmatamento 13

Figura 6: Taxas anuais de desmatamento na Amazônia Legal em $\mathrm{Km}^{2} / \mathrm{ano}$, registradas pelo Sistema PRODES do INPE.

Figura 7: Taxas anuais de desmatamento nos estados da Amazônia Legal, entre 2004 e 2013 em $\mathrm{Km}^{2} / \mathrm{ano}$.

Figura 8: Taxas Anuais de Desmatamento nos Estados que Apresentam menores Taxas de Desmatamento, entre 2004 e 2013 em Km²/ano. 23

Figura 9: Estimativa de emissões de $\mathrm{CO} 2$ resultantes de processos de desmatamento. 23

Figura 10: Evolução do efetivo dos rebanhos bovinos nos estados da Amazônia Legal entre 1988 e 2013.

Figura 11: Evolução da área de plantação de soja nos estados da Amazônia Legal, entre 1990 e 2013.

Figura 12: Relação entre desmatamento e taxas de câmbio, entre 2004 e 2013 ..................... 51

Figura 13: Relação entre desmatamento e preços soja e boi, entre 1997 e 2013....................52

Figura 14: Concessões de crédito rural para atividades pecuárias, entre 2002 e 2011 ...........54

Figura 15: Concessões de crédito rural para atividades agrícolas (soja), entre 2002 e 2011...55

Figura 16: Contribuição relativa dos polígonos de desmatamento <25ha para o total anual desmatado entre 2005 e 2012

Figura 17: Contribuição relativa dos polígonos de desmatamento <25ha para o total anual desmatado entre 2005 e 2012, no Acre

Figura 18: Contribuição relativa dos polígonos de desmatamento <25ha para o total anual desmatado entre 2005 e 2012, no Amapá.....

Figura 19: Contribuição relativa dos polígonos de desmatamento <25ha para o total anual desmatado entre 2005 e 2012, no Amazonas 
Figura 20: Contribuição relativa dos polígonos de desmatamento <25ha para o total anual desmatado entre 2005 e 2012, no Maranhão

Figura 21: Contribuição relativa dos polígonos de desmatamento <25ha para o total anual desmatado entre 2005 e 2012, no Mato Grosso.

Figura 22: Contribuição relativa dos polígonos de desmatamento <25ha para o total anual desmatado entre 2005 e 2012, no Pará

Figura 23: Contribuição relativa dos polígonos de desmatamento <25ha para o total anual desmatado entre 2005 e 2012, em Rondônia

Figura 24: Contribuição relativa dos polígonos de desmatamento <25ha para o total anual desmatado entre 2005 e 2012, em Roraima..

Figura 25: Contribuição relativa dos polígonos de desmatamento <25ha para o total anual desmatado entre 2005 e 2012, em Tocantins

Figura 26: Desmatamento nos Municípios Prioritários, entre 2007 e 2013. Fonte: INPEPRODES, 2014. 66

Figura 27: Zonas e polos madeireiros na Amazônia Legal em 1997. Fonte: Nepstad et al., 1999.

Figura 28: Zonas e polos madeireiros na Amazônia Legal em 1998. Fonte: SBF \& IMAZON, 2003. 72

Figura 29: Zonas e Polos Madeireiros na Amazônia Legal em 2004. Fonte: SBF \& IMAZON, 2005. .72

Figura 30: Zonas e polos madeireiros na Amazônia Legal em 2009. Fonte: SBF \& IMAZON, 2010 .73

Figura 31: Produção de Toras de Madeira na Amazônia Legal de acordo com dados do IBGE. Fonte: IBGE, 2014. 73

Figura 32: Produção de Toras de Madeira na Amazônia Legal de acordo com dados do IBGE. Fonte: IBGE, 2014. 74

Figura 33: Taxas de degradação florestal na Amazônia Legal entre 2007 e 2013. Fonte: INPE-DEGRAD, 2014. .77

Figura 34: Áreas degradadas em um ano convertidas a corte raso (desmatamento) no ano seguinte, de 2007 a 2013. .77

Figura 35: Relação entre taxa de desmatamento e precipitação. .78

Figura 36: Relação entre taxa de desmatamento e precipitação na estação seca 79

Figura 37: Relação entre número de focos de queimada e precipitação na Amazônia Legal. 79 


\section{LISTA DE TABELAS}

Tabela 1: Subgrupos de Trabalho e Áreas de Atuação do PPCDAm...................................... 26

Tabela 2: Síntese de Recomendações para Revisão do PPCDAm Fase II.............................. 32

Tabela 3: Síntese dos fatores predominantes responsáveis pela redução das taxas de desmatamento na Amazônia Legal entre 2005 e 2013, segundo principais atores envolvidos

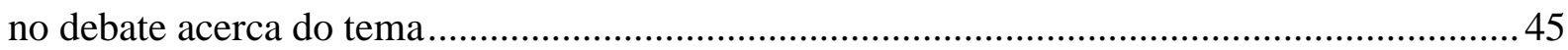

Tabela 4: Classificação de Unidades de Conservação .............................................................59 
INTRODUÇÃ $O$........................................................................................................... 1 1 CAPÍTULO 1 - CARACTERIZAÇÃo DOS PROCESSOS DE DESMATAMENTO NA AMAZÔNIA LEGAL.................................................................5 1.1 PROCESSOS DE DEGRADAÇÃO FLORESTAL E DESMATAMENTO 5 1.1.1 Características das Atividades Pecuárias........................................................... 8

1.1.2 Características da Produção de Soja na Amazônia Legal .............................. 9

1.1.3 Características dos Investimentos em Infraestrutura ....................................11

1.1.4 Características da Exploração Madeireira na Amazônia Legal ..................12 1.1.5 A Questão Fundiária na Amazônia Legal e os Processos de Ocupação Ilegal de Terras .15

I.3 IMPACTOS DOS PROCESSOS DE DESMATAMENTO E DEGRADAÇÃO FLORESTAL 16

1.3.1 Características dos Impactos do Desmatamento e Degradação Florestal em Âmbito Ecológico. 16 2

CAPÍTULO 2 - MONITORAMENTO E MEDIDAS DE CONTROLE DE PROCESSOS DE DESMATAMENTO NA AMAZÔNIA LEGAL .20

2.1 MONITORAMENTO DAS MUdANÇAS DE USO DO SOLO Na AMAZÔNIA LEGaL 20 MEdidAS de CONTROLE AO PROCESSO DE DESMATAMENTO. .24

2.2.1 O Plano de Ação para Prevenção e Controle do Desmatamento na Amazônia Legal (PPCDAm). .25

2.2.2 Promulgação do Decreto 6321/07: Prevenção, Monitoramento e Controle de Desmatamento no Bioma Amazônia .34

2.2.3 A Definição de Novas Regras para Obtenção de Crédito Rural: Resolução $3545 / 08 \quad 36$

2.2.4 A Implantação do Processo de Cadastro Ambiental Rural ...........................37

2.2.5 Implementação das Moratórias da Soja e da Carne .......................................38

2.2.6 Formulação de Pactos Setoriais...........................................................................39

2.2.7 Formulação do Pacto pela Valorização da Floresta e pelo Fim do Desmatamento na Amazônia Brasileira 39 
2.2.8 Estabelecimento de Protocolos de Intenções pela Responsabilidade Socioambiental entre MMA, BNDES, CEF, BASA, BB e BNE e entre MMA e FEBRABAN (chamado de Novo Protocolo Verde) .........................................................39

2.2.9 Firmamento de Protocolo de Intenções entre MMA e FIESP .................... 40

2.2.10 Combate à Ilegalidade no Setor Madeireiro ................................................ 40

3 CAPÍTULO 3 - ANÁLISE DOS FATORES QUE LEVARAM À REDUÇÃO DE DESMATAMENTO ENTRE 2005 E 2013 NA AMAZÔNIA LEGAL . 44 3.1 DinÂMICAS RELACIONADAS A ATIVIDADES AGROPECUÁRIAS ...................... 48 3.2 OS IMPACTOS DA RESOLUÇÃo 3545: RESTRIÇÃo DE CONCESSÃo DE

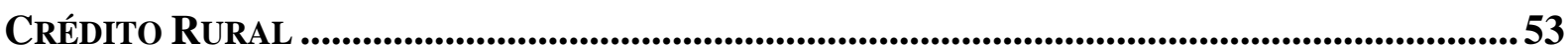

3.3 Os Impactos das Moratórias da SoJa e da Carne E EMbargos COMERCIAIS 55

3.4 OS IMPACTOS DO PPCDAM 57

3.4.1 A Criação e Expansão de Áreas Protegidas . 58

3.4.2 O Aprimoramento do Monitoramento por Satélites da Amazônia Legal.61

3.4.3 O Aprimoramento das Medidas de Fiscalização na Amazônia Legal ....... 67 IMPACTOS DO CADASTRO AMBIENTAL RURAL..........................................................68 DINÂMICAS RELACIONADAS AO SETOR MADEIREIRO ........................................ 69 


\section{INTRODUÇÃO}

Em um cenário de mudanças climáticas globais, o Brasil enfrenta o desafio de estabelecer padrões de desenvolvimento econômico associado a baixas emissões de carbono. Assim, no ano de 2009, foi instituída a Política Nacional sobre a Mudança do Clima (PNMC), que oficializou a meta voluntária brasileira de redução de emissões de Gases de Efeito Estufa (GEE) entre 36,1\% e 38,9\% das emissões projetadas até o ano de 2020, (BRASIL, 2009). Para que tal meta seja alcançada, é imprescindível que se garanta uma forte redução de emissões de GEE oriundas de desmatamento e degradação florestal. Neste contexto, o Decreto 7.390 de 9 de dezembro de 2010 oficializou a meta de redução de $80 \%$ dos índices anuais de desmatamento na Amazônia Legal, até o ano de 2020, em relação à média verificada entre os anos de 1996 a 2005 (BRASIL, 2010).

A Amazônia Legal, região definida pela Lei 1806 de 6 de janeiro de 1953, é formada pelos estados que compreendem a componente brasileira da floresta amazônica: Acre, Amazonas, Amapá, Pará, Roraima, Rondônia, Tocantins, Mato Grosso e parte do Maranhão situada a oeste do meridiano $44^{\circ}$ (RAISG, 2012). A Floresta Amazônica é a maior floresta tropical contínua do planeta (Andersen et al., 2002; Verburg et al., 2014) e possui ampla variedade de entornos. Embora situada inteiramente em zona tropical, as características ecológicas não são uniformes ao longo do território. As regiões fitoecológicas abrangem: floresta de terra firme, floresta de várzea, mata de igapó, campinaranas e campinas (Carvalho, 2004). A bacia hidrográfica da região - a maior do mundo - é composta por diversificados cursos d'água: rios de água branca (alta carga de sedimentos; $\mathrm{pH}$ neutro; grande concentração de sais minerais); rios de água clara (heterogêneos, sendo aqueles que nascem nos sedimentos cretáceos depositados acima do escudo do Brasil Central ácidos e pobres em minerais e aqueles que nascem na faixa carbonífera ao norte e sul do baixo amazonas com pH neutro e maior concentração de sais minerais); e rios de água preta (não carregam grande quantidade de sedimentos; pH ácido; baixíssima concentração de sais minerais) (Carvalho, 2004).

A enorme diversidade de ambientes, com mais de 600 tipos diferentes de habitats terrestres e de água doce, abriga rica biodiversidade: cerca de 45.000 espécies de plantas e vertebrados conhecidos (MMA/SBF, 2013), o que corresponde aproximadamente a 1/4 das espécies terrestres globais (Malhi et al., 2008 apud Field et al., 1998). A evaporação e condensação de vapor de água na floresta Amazônica são motores da circulação atmosférica

global, tendo efeitos nas precipitações ao longo da América do Sul e outras regiões (Malhi et al., 2008; Werth et al., 2002; Barbosa et al., 2015). Aproximadamente oito trilhões de 
toneladas de água evaporam anualmente, influenciando o fluxo de calor e a circulação atmosférica global (IPCC, 2007). Calcula-se, ainda, que uma fração significativa da precipitação na região é reciclada regionalmente pela floresta (Malhi et al., 2008). Estima-se que na floresta Amazônica seja realizada $15 \%$ da fotossíntese terrestre global (Field et al., 1998) e que a biomassa ali encontrada contenha 100 bilhões de toneladas de carbono (Malhi et al. 2006; Saatchi et al. 2007).

A manutenção da integridade biótica dos serviços ecossistêmicos (em níveis local, regional e global) amazônicos requer o entendimento aprimorado a respeito das vulnerabilidades e resiliência de seu ecossistema (Davidson et al., 2012). Nesse sentido, as mudanças de uso do solo e seus impactos configuram um ponto crítico a ser cuidadosamente estudado pela comunidade científica. Atualmente, a Amazônia Legal enfrenta um período de transição causado por interações entre fatores socioeconômicos e climáticos, que ocasionam impactos negativos no funcionamento do ecossistema (Nepstad et al., 2008). A Figura 1 explicita as causas, processos e consequências advindas de tais interações.

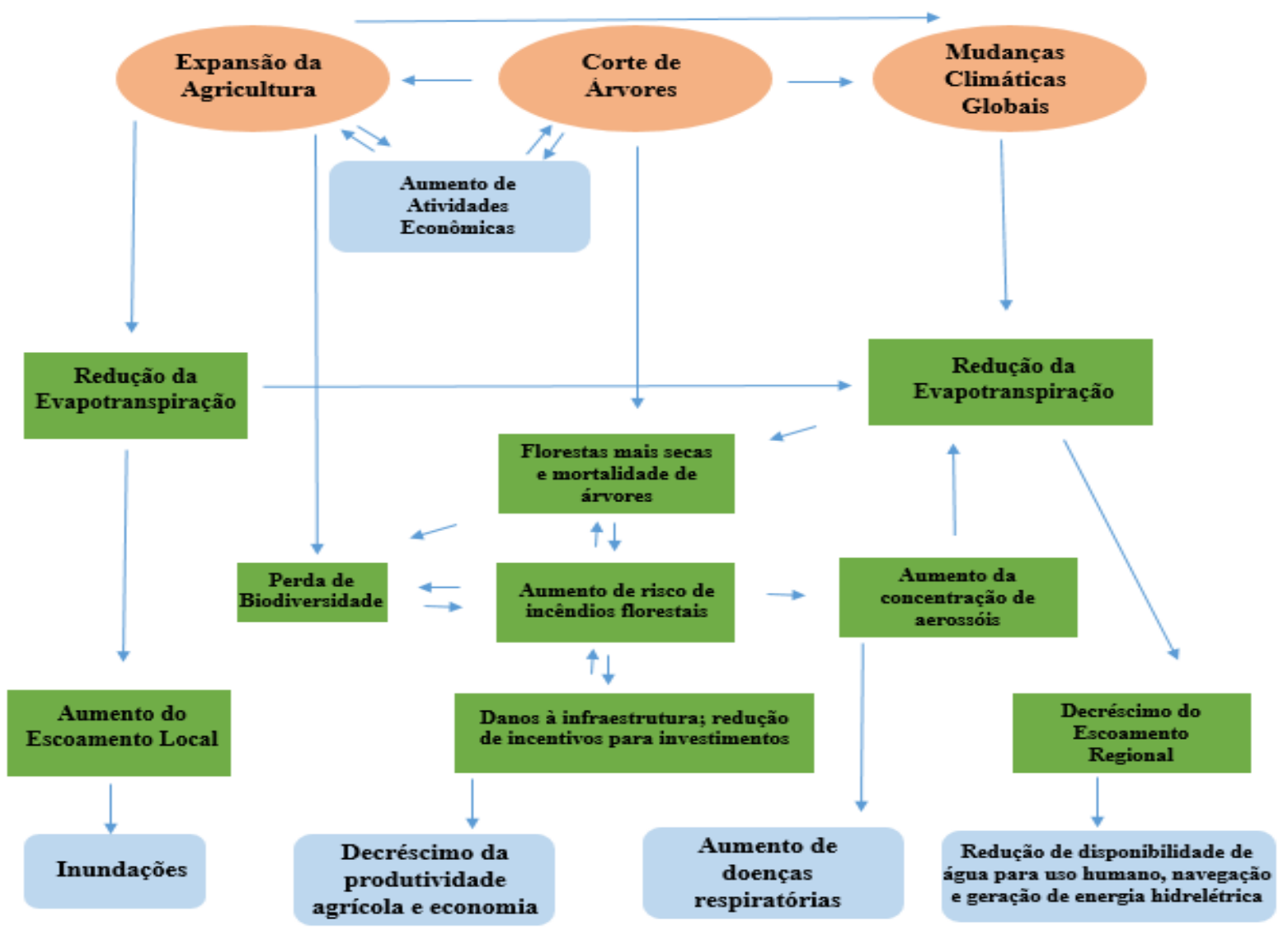

Figura 1: As complexas interações entre clima, uso do solo, fogo, hidrologia, ecologia e dimensões humanas na Amazônia. Causas: formas ovais laranja; processos: retângulos verdes e consequências para a sociedade: retângulos azuis. Fonte: Adaptado de Davidson et al., 2012.

A Figura 1 explicita que, além de fatores ecológicos, a preservação da floresta 
Amazônica está fortemente associada a questões socioeconômicas. Além dos pontos ilustrados na Figura 1, o desmatamento acarreta como impactos negativos: o aumento da incidência de doenças tropicais; o estímulo a atividades ilegais e exclusão social que levam a conflitos sociais; desordem, violência e perda do conhecimento tradicional. Assim, ocorre a perda de oportunidades para o uso sustentável da floresta, incluindo a produção de mercadorias tradicionais tanto por manejo florestal para madeira, como por extração de produtos não-madeireiros (Hetch, 2011). A natureza insustentável do uso da terra faz com que as oportunidades perdidas de manter a floresta em pé sejam significativas a longo prazo (Fearnside, 2006).

Em um contexto de mudanças globais, tanto socioeconômicas quanto climáticas, diversos estudos buscam elucidar como tornar possível a manutenção de baixas taxas de desmatamento na Amazônia Legal (Andersen, 2002; Arima et al., 2014; Assunção et al., 2013a; Azevedo et al., 2014; Barreto \& Silva, 2013; Carvalho et al., 2001; Fearnside 2003, 2005, 2006; Hetch, 2011; Lima et al., 2009; Nepstad et al., 2004, 2006, 2008, 2014; Prates, 2008; Ruviaro, 2013; Soares-Filho, 2006, 2010a; Verbug et al., 2014).

A compreensão dos fatores que levaram à redução de desmatamento na região observada a partir de 2005 é um ponto fundamental para que a manutenção de baixas taxas seja possível. No entanto, ainda existem fortes divergências relacionadas à identificação dos vetores responsáveis por tal redução.

O presente estudo foi desenvolvido com o objetivo de fornecer subsídios teóricos para a compreensão dos principais fatores políticos, econômicos e culturais responsáveis pela redução das taxas de desmatamento na Amazônia Legal, entre os anos de 2005 e 2013.

Foi realizada pesquisa qualitativa, através da coleta e análise de dados primários e secundários. Os dados primários foram obtidos através da realização de entrevistas com os principais atores envolvidos no debate em torno das dinâmicas de desmatamento na região de estudo: Alberto Setzer (Instituto Nacional de Pesquisas Espaciais - INPE), Britaldo Soares (Universidade Federal de Minas Gerais), Dalton Valeriano (Instituto Nacional de Pesquisas Espaciais - INPE), Paulo Moutinho (Instituto de Pesquisa Ambiental da Amazônia), Philip Fearnside (Instituto Nacional de Pesquisas da Amazônia), Raoni Rajão (Universidade Federal de Minas Gerais) e Tasso Azevedo (Serviço Florestal Brasileiro (2006 - 2009). A entrevista baseou-se na aplicação de questionários idênticos, previamente elaborados, a todos os atores, 
conforme constam nos Anexos I-VII ${ }^{1}$. Os dados secundários foram obtidos através de (i) revisão de literatura a partir da compilação da produção científica publicada sobre o tema até o presente momento; (ii) coleta de dados de taxas anuais de desmatamento (INPE-PRODES), taxas mensais de desmatamento (INPE-DETER), taxas anuais de degradação florestal (INPEDEGRAD) e focos de queimada anuais (INPE-QUEIMADAS) na região de estudo; (iii) coleta de dados de precipitação anual e mensal na região de estudo (Instituto Nacional de Meteorologia - INMET - e Agência Nacional de Águas - ANA); (iv) coleta de dados de efetivos dos rebanhos e plantação de soja na região de estudo (Instituto Brasileiro de Geografia e Estatística - IBGE); (v) coleta de dados de concessão de crédito rural para atividades pecuárias e plantação de soja (Banco Central do Brasil - BCB); (vi) coleta de dados de taxas cambiais (BCB); (vii) coleta de dados de preços de commodities de soja e carne de boi (Centro de Estudos Avançados em Economia Aplicada - CEPEA); e (viii) coleta de dados de produção madeireira na região de estudo (Serviço Florestal Brasileiro - SBF/Instituto do Homem e Meio Ambiente da Amazônia -IMAZON). Foi utilizado o Software QGis para análise dos tamanhos de polígonos de desmatamento.

O estudo foi estruturado em quatro capítulos. O primeiro capítulo trata da caracterização, a partir de revisão de literatura, do processo de desmatamento e da tendência histórica de mudanças de uso do solo na Amazônia Legal, bem como dos impactos socioambientais ocasionados por processos de degradação e desmatamento. O segundo capítulo trata dos sistemas de monitoramento (desmatamento, degradação florestal e incêndios florestais) e das principais medidas de combate ao desmatamento aplicadas na da região em questão. No terceiro capítulo, os fatores que levaram à redução de desmatamento verificada entre 2005 e 2013 são apresentados e analisados com base nos resultados das realizações de entrevistas, levantamento bibliográfico e compilação de dados estatísticos. O quarto capítulo traz as conclusões e recomendações gerais do estudo.

${ }^{1}$ Foram transcritas as questões diretamente vinculadas aos questionários. Comentários adicionais são citados no texto e referenciados. Azevedo (2014) e Rajão (2014) somente responderam à primeira questão do questionário por motivos relativos a tempo disponível para concessão da entrevista. 


\section{CAPÍTULO 1 - CARACTERIZAÇÃO DOS PROCESSOS DE DESMATAMENTO NA AMAZÔNIA LEGAL}

\subsection{PROCESSOS DE DEGRADAÇÃO FLORESTAL E DESMATAMENTO}

O desmatamento é um processo que tem início com a floresta intacta e tem fim com a conversão completa da floresta original em outras coberturas (INPE, 2008). O processo é caracterizado em quatro etapas: (i) degradação florestal de intensidade leve, onde são identificadas clareiras pequenas; (ii) degradação florestal de intensidade moderada, estágio intermediário em que ainda são encontradas árvores de grande porte e sub-bosque conservado; (iii) degradação florestal de intensidade alta, onde há perda significativa das árvores de grande porte, com perda concomitante do sub-bosque, mas muitas árvores mortas por queimadas contínuas permanecem em pé; e (iv) corte raso (desmatamento), quando ocorre a retirada completa da vegetação original (MCT \& INPE, 2008). A Figura 2 ilustra as características da cobertura vegetal nos estágios de floresta não alterada, degradação de intensidade leve, degradação de intensidade moderada, degradação de intensidade alta e corte raso (desmatamento).

\begin{tabular}{|c|c|c|c|}
\hline & $\begin{array}{l}\text { Predomínio de tonalidade } \\
\text { verde, textura rugosa e } \\
\text { sombra. Padrão } \\
\text { semelhante às florestas da } \\
\text { região. Maioria do } \\
\text { perímetro contíguo tem o } \\
\text { mesmo padrão. }\end{array}$ & $\begin{array}{l}\text { Cobertura florestal, } \\
\text { textura heterogênea, } \\
\text { com sombra, } \\
\text { indicando a } \\
\text { estrutura florestal } \\
\text { complexa e não } \\
\text { alterada. }\end{array}$ & $\begin{array}{l}\text { Floresta não } \\
\text { alterada }\end{array}$ \\
\hline & $\begin{array}{l}\text { Tonalidade magenta, ou } \\
\text { verde muito claro } \\
\text { (esmaecido). Forma } \\
\text { regular, textura lisa, limites } \\
\text { bem definidos entre o } \\
\text { polígono (solo exposto) e a } \\
\text { matriz florestal. }\end{array}$ & $\begin{array}{l}\text { Predomínio de solo } \\
\text { exposto ou } \\
\text { pastagem em } \\
\text { formação. }\end{array}$ & Corte Raso \\
\hline & $\begin{array}{l}\text { Predomínio de tonalidade } \\
\text { verde e padrão de floresta, } \\
\text { com presença de feições } \\
\text { de tonalidade magenta ou } \\
\text { roxa de tamanho pequeno, } \\
\text { com baixa densidade e } \\
\text { freqüência. }\end{array}$ & $\begin{array}{l}\text { Predomínio de } \\
\text { cobertura florestal } \\
\text { com manchas de } \\
\text { solo exposto } \\
\text { indicando a } \\
\text { presença de pátios e } \\
\text { indícios de acesso. }\end{array}$ & $\begin{array}{c}\text { Floresta } \\
\text { Degradada de } \\
\text { Intensidade Leve }\end{array}$ \\
\hline & $\begin{array}{l}\text { Predomínio de tonalidade } \\
\text { verde e padrão de floresta, } \\
\text { com presença de feições } \\
\text { de tonalidade magenta ou } \\
\text { roxa, de tamanho médio, } \\
\text { com média densidade e } \\
\text { freqüência. }\end{array}$ & $\begin{array}{l}\text { Predomínio de } \\
\text { cobertura florestal } \\
\text { com manchas de } \\
\text { solo exposto } \\
\text { indicando a } \\
\text { presença de pátios } \\
\text { de estocagem de } \\
\text { madeira, ramais e } \\
\text { clareiras. }\end{array}$ & $\begin{array}{l}\text { Floresta } \\
\text { Degradada de } \\
\text { Intensidade } \\
\text { Moderada }\end{array}$ \\
\hline and & $\begin{array}{l}\text { Predomínio de tonalidade } \\
\text { magenta/roxa (clareiras } \\
\text { grandes com indicação de } \\
\text { fogo) ou verde (com textura } \\
\text { lisa) em associação com } \\
\text { manchas que apresentam } \\
\text { padrão de floresta. }\end{array}$ & $\begin{array}{l}\text { Presença de } \\
\text { grandes clareiras } \\
\text { com solo exposto, } \\
\text { vegetação } \\
\text { secundária e/ou } \\
\text { área extensa de } \\
\text { cicatriz de fogo } \\
\text { florestal, } \\
\text { combinadas com } \\
\text { manchas florestais. }\end{array}$ & $\begin{array}{c}\text { Floresta } \\
\text { Degradada de } \\
\text { Intensidade Alta }\end{array}$ \\
\hline
\end{tabular}

Figura 2: Características da cobertura vegetal em diferentes estágios de perturbação florestal. Fonte: MCT/INPE, 2008. 


\subsection{TendênCia Histórica da Dinâmica das Mudanças de Uso do Solo na Amazônia Legal}

As mudanças de uso do solo na Amazônia Legal são altamente heterogêneas, tanto espacial quanto temporalmente. A paisagem atual da região Amazônica deriva das diferentes fases de desenvolvimento ocorridas ao longo dos últimos 50 anos. A contribuição das atividades econômicas desenvolvidas na Amazônia Legal para o desmatamento teve início na fase do regime militar (1964 a 1985), quando programas específicos de desenvolvimento e ocupação da região estimularam o crescimento populacional e o desenvolvimento econômico da região. Nesse período, as medidas governamentais não buscavam harmonizar as dimensões sociais, ambientais, políticas e econômicas de desenvolvimento (Prates, 2008). Laurance et al. (2001) enfatizam o papel crítico da construção de estradas e rodovias e do processo desordenado de ocupação de solo na destruição de florestas em tal período.

Durante o final dos anos 80 e nos anos 90, projetos de colonização em larga escala, a concessão de créditos e os investimentos realizados na região levaram à perda de aproximadamente 18 milhões de hectares de área florestada (Alvez et al., 2007; INPEPRODES, 2014). As correlações entre desmatamento e o avanço do setor agropecuário tornaram-se mais altas a partir de 1994, devido à reforma monetária e alcance de estabilidade macroeconômica brasileira, bem como à inserção do país nos mercados globais como importante fornecedor de soja e carne (Arima et al., 2014).

Em 2001, aproximadamente $837.000 \mathrm{~km}^{2}$ das florestas Amazônicas originais haviam sido devastadas no Brasil (Soares-Filho et al. 2006). A devastação se concentrou no "arco do desmatamento", nas margens leste e sudeste da Amazônia Legal. No período que compreende os anos de 1998-2006, as taxas de desmatamento em tal região foram, em média, de 18.100 $\mathrm{km}^{2}$ ano $^{-1}$, tendo ocorrido no ano de 2004 o desmatamento de aproximadamente $27.400 \mathrm{~km} 2$ das áreas florestadas (Malhi et al. 2008). Nesse período, as mudanças de uso do solo e consequentes elevadas taxas de desmatamento observadas deveram-se a:

- Demandas internacionais crescentes por commodities agroindustriais e escassez de terras apropriadas à expansão agrícola nos EUA, Europa Ocidental, China e outros países (Nepstad, 2006);

- $\quad$ Expansão do plantio de cana-de-açúcar para a produção de etanol no estado de São Paulo, o que provocou o deslocamento da produção de soja e rebanhos bovinos (Nepstad, 2008);

- $\quad$ Fragilidade das políticas ambientais brasileiras (Nepstad, 2008). 
A Figura 3, abaixo, traz um resumo dos principais fatores responsáveis pelo desmatamento na Amazônia Legal:

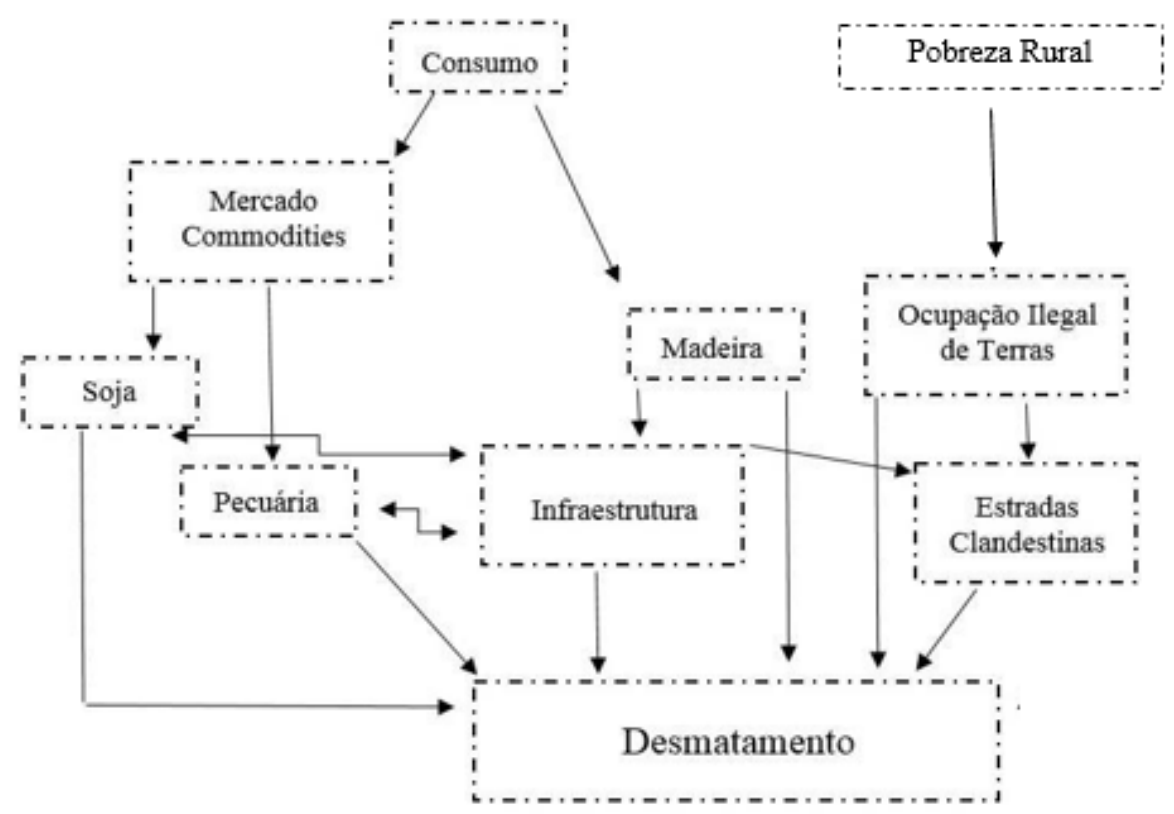

Figura 3: Vetores de desmatamento na Amazônia Legal. Fonte: Elaboração Própria.

O desenvolvimento e o desmatamento na Amazônia Legal diferem entre os estados que a compõe, pois as atividades econômicas e a dinâmica populacional têm instensidades e evoluções diferentes na região. Em termos de expressividade de taxas de desmatamento, a Amazônia Legal está dividida em três regiões: (i) Arco do Desmatamento (Porções leste e sudeste da Amazônia Legal), região relativamente populada e desmatada; (ii) Amazônia Central, onde novas fronteiras de desmatamento estão se estabelecendo e (iii) Amazônia Ocidental, área predominantemente não perturbada. A heterogeneidade dos padrões de ocupação da Amazônia Legal só pode ser explicada quando analisados diversos fatores como condições ambientais favoráveis e acesso a mercados - relacionados à organização dos setores produtivos (Aguiar, Câmara \& Escada, 2007). Chomitz \& Thomas (2003) afirmam que as áreas mais úmidas na Amazônia Legal exibem menores taxas de conversão de florestas para usos agropecuários; a probabilidade de que a terra seja usada para tais atividades declina consideravelmente com o aumento de precipitação, como ocorre na Amazônia Ocidental.

Hetch (2011) afirma que a Amazônia Legal pode ser vista como composta por paisagens de "Natureza Ür" (natureza selvagem), "Neo-Naturezas" (as paisagens agroindustriais modernistas, onde a terra é basicamente um substrato para a produção silvo- 
industrial, agroindustrial ou de gado) e "Naturezas-Sociais" (os mosaicos de florestas habitadas); cada uma destas paisagens se referem a diferentes regimes e se relacionam com diferentes causas de desmatamento.

Prates (2008) aponta que as diferenças entre as dinâmicas de desmatamento em cada estado resultam de fatores de ordem econômica, política, histórica e social particulares a cada um destes, o que se reflete na distribuição e expressividade dos vetores de desmatamento em cada estado. Souza et al. (2013) afirmam que áreas onde são encontrados menores níveis de tecnologia coincidem com maiores taxas de desmatamento.

\subsubsection{Características das Atividades Pecuárias}

A atividade pecuária está presente em pequenas e grandes propriedades, na fronteira mais antiga e nas zonas de expansão de ocupação da floresta, e tem se expandido quase continuamente em toda a história recente do desenvolvimento da Amazônia Legal. Os processos associados à expansão da pecuária têm se mostrado extremamente resilientes. Isso se dá não por uma causa única, como a rentabilidade específica da atividade, mas é o resultado da interação complexa de múltiplas causas (Rivero et al., 2009; Rodrigues, 2004). Essas causas estão associadas, principalmente, à liquidez da atividade, à relativa simplicidade dos processos produtivos, e ao baixo nível de investimento de capital necessário à sua instalação (Rivero et al., 2009).

De 1990 a 2006, o rebanho bovino cresceu a uma taxa média de 6,74\% ao ano na Amazônia Legal, enquanto nas outras regiões do Brasil o crescimento médio do rebanho foi de $0,57 \%$ ao ano (Rivero et al., 2009). Com essas taxas, segundo os dados da Pesquisa Pecuária Municipal do IBGE, o rebanho cresceu de 26 milhões de cabeças em 1990 para 73,7 milhões em 2006, o que representa um crescimento de mais de $180 \%$ em 16 anos (Rivero et al., 2009). A maior parte de tal crescimento ocorreu especialmente nos estados de Mato Grosso, Pará e Rondônia (IBGE, 2014). O crescimento acompanhou o aumento da demanda interna e externa de carne bovina, e foi influenciado por outros fatores, como a sucessiva redução de custos de transporte, o aumento da produtividade da atividade e o ainda relativamente pequeno preço da terra na região (Rivero et al., 2009).

A indústria do gado na Amazônia Legal não estava inicialmente ligada ao mercado internacional, devido a restrições relacionadas à febre aftosa. No entanto, com a erradicação de tal doença, em 2003, com a desvalorização da moeda real, com o aprimoramento dos processos de produção de carne bovina e com o advento da proliferação da doença da "vaca louca" na Europa, a exportação dos produtos pecuários oriundos de tal região foi facilitada 
(DeFries et al., 2013). Em 2005, cerca de 30\% dos frigoríficos em Mato Grosso, Tocantins, Rondônia e Pará estavam autorizados a exportar carne e subprodutos animais (farinhas de carne e osso, miúdos congelados e produtos agregados diversos) (Barreto et al., 2008). Entre 2000 e 2006, o Mato Grosso foi o principal exportador e o maior responsável pelo crescimento das exportações da Amazônia (Barreto et al., 2008).

A pecuária é a principal atividade econômica e um dos principais vetores de desmatamento na Amazônia Legal, sendo os médios e grandes pecuaristas os atores mais expressivos em tais atividades. Os pequenos proprietários atuam como fornecedores de mãode-obra ou agentes intermediários, mas sua contribuição direta para os desmatamentos é pequena (Margulis, 2003).

\subsubsection{Características da Produção de Soja na Amazônia Legal}

O cultivo da soja, em particular, representa um acréscimo considerável às atividades agrícolas na Amazônia Legal. Embora a região produza uma grande variedade de culturas, a soja predomina, em termos de lucros (Alves et al., 2007). A modernização da produção da soja permitiu o extremo avanço da agricultura mecanizada na Amazônia Legal, com a introdução de sistemas de produção altamente capitalizados (Alves et al., 2007). O boom da soja na região, de modo geral, representa uma parte importante do crescimento econômico nacional, com a expansão de uma produção anual de 20 milhões de toneladas em 1990 para 50 milhões em 2004 (Alves et al., 2007). A expansão da produção de soja na região Amazônica está essencialmente associada a: (i) demandas internacionais crescentes por commodities agroindustriais (em grande parte motivadas pela robusta expansão econômica da China e pelo consumo global crescente de óleos vegetais e de soja para consumo avícola, suíno e bovino) e escassez de terras apropriadas à expansão agrícola nos EUA, Europa Ocidental, China e outros países (Nepstad, 2008 apud Brown, 2004); (ii) programas brasileiros que vêm produzindo variedades de soja e outros grãos que são resistentes às altas temperaturas e umidade da região Amazônica (Nepstad 2008), criando incentivos para que atividades agrícolas sejam desenvolvidas na região; (iii) investimentos em infraestrutura inferindo no declínio substancial dos custos de transporte; (iv) incentivos governamentais para desenvolvimento econômico da região Amazônica.

Ao passo que a população mundial continua a crescer, espera-se que a demanda por proteína cresça significativamente. Até 2025 , a demanda por carne de porco e de vaca deverá crescer mais de $20 \%$ e a demanda por carne de frango deverá crescer aproximadamente $30 \%$ (KPMG, 2013). O papel da soja é fundamental em assegurar que se alcance esse desafio, por 
ser um dos principais componentes na alimentação animal. Logo, o aumento da produção de tal commodity deverá ocorrer em ritmo significativo. A Figura 4, abaixo, ilustra a evolução da produção mundial de soja e carne (de porco e frango) desde 1961, projetada até o ano de 2020.

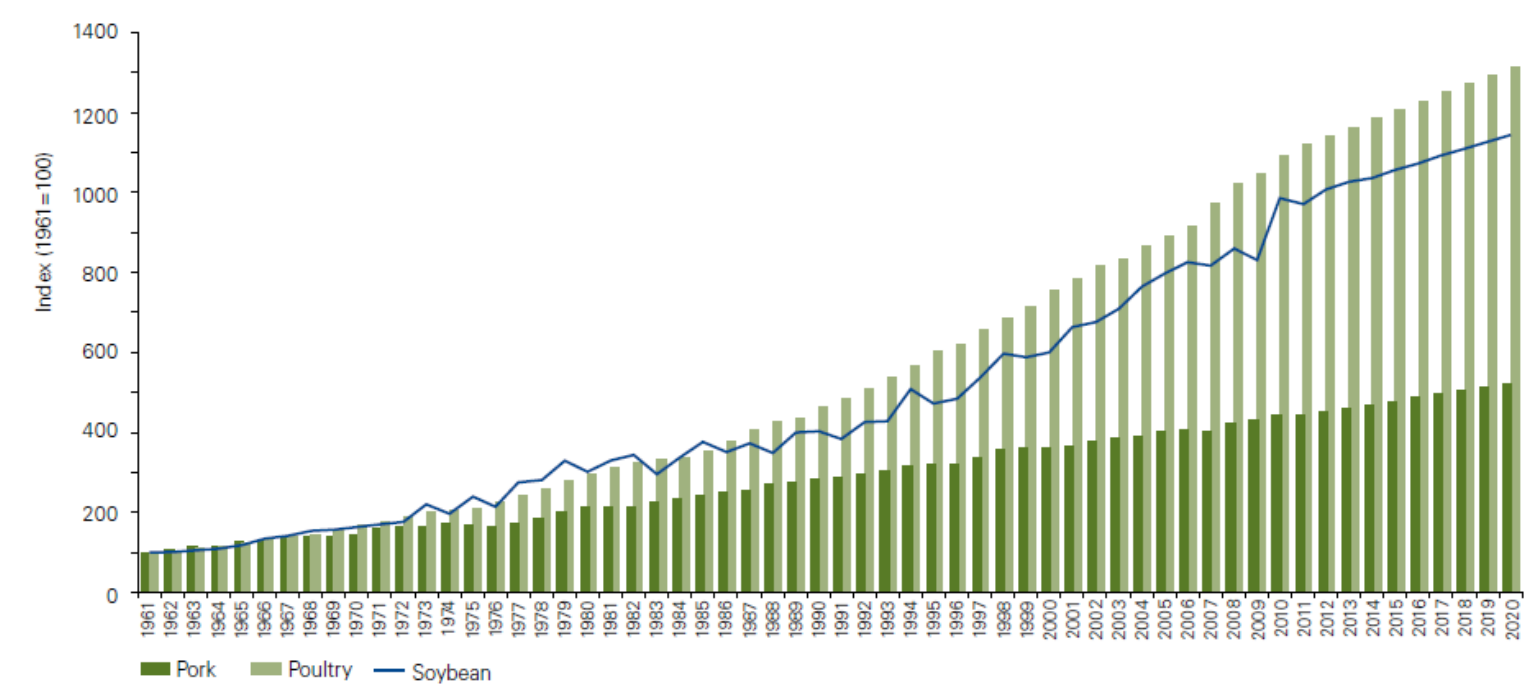

Figura 4: Evolução da produção mundial de soja e carne (de porco e frango), projetada até o ano de 2020. Fonte: KPMG, 2013.

Discussões relacionadas a um cenário futuro apontam que a produção de soja no Brasil poderia facilmente chegar a 73 milhões de toneladas até 2020, com mais de 55 milhões de toneladas exportadas para os mercados globais (Alves et al., 2007). A soja afeta, potencialmente, a cobertura da floresta amazônica por meio de dois mecanismos. Em primeiro lugar, a soja pode estar impulsionando o gado para o interior da floresta, já que grande parte da expansão da produção de soja ocorre em áreas previamente utilizadas para criação de gado. Isto ocasiona a valorização das áreas utilizadas para pasto e a consequente capitalização dos pecuaristas, que podem adquirir novas terras em regiões antes intocadas (Alves et al., 2007).

A relevância desse processo reside no fato, conforme descrito anteriormente, de que a criação de gado é um dos principais fatores de desmatamento na região Amazônica. Em segundo lugar, se as condições de mercado forem mais favoráveis para a soja, a produção avança diretamente para as áreas de floresta primária, antes da pecuária (Alves et al., 2007). A importância crescente da conversão direta para áreas de cultivo definiu uma tendência de perdas de áreas de floresta na Amazônia Legal desde o início dos anos 2000 (Davidson et al. 2012). Em particular, as operações mecanizadas que envolvem soja produzem, tipicamente e de forma rápida, grandes clareiras para acelerar o início da produção (Alves et al., 2007). 


\subsubsection{Características dos Investimentos em Infraestrutura}

Os investimentos em larga escala, por parte do governo brasileiro, para o desenvolvimento da região Amazônica incluem a contrução de portos, hidrovias, usinas hidroelétricas e a pavimentação de estradas (Fearnside \& Laurance, 2002; Fearnside, 2005; Tundisi, 2007). A pavimentação de estradas objetiva integrar as rodovias brasileiras a outros países da América do Sul com acesso ao oceano Pacífico e facilitar o acesso ao oceano Atlântico, encurtando distâncias entre a Amazônia Legal e os mercados europeus e asiáticos (Verburg et al., 2014).

Duas forças econômicas têm sido as principais propulsoras para a expansão e abertura de estradas na região: a indústria da soja e a indústria madeireira (Nepstad et al., 2001; Nepstad et al., 2004; Carvalho et al., 2001; Fearnside, 2001). Para a indústria da soja, tal expansão incorre em menores custos de transporte através do aprimoramento de acesso aos portos Amazônicos; para a indústria madeireira, o acesso a uma maior quantidade de espécies (e volume total de madeira) é facilitado - ocasionando maiores danos relacionados à degradação oriunda dos processos de extração madeireira. Verburg et al. (2014) afirmam que a redução dos custos de transporte em áreas onde ainda não são encontradas atividades antropogênicas expressivas podem levar ao aumento de desmatamento.

Os investimentos em infraestrutura tendem a provocar uma forte valorização de terras em sua área de influência, mesmo antes de sua realização. Em muitos casos, a mera expectativa de realização de grandes obras estimula processos de especulação fundiária, grilagem de terras públicas e abertura de novas frentes de desmatamento. Há maior migração para as áreas contempladas com novas rodovias, o que intensifica conflitos sociais (Verburg et al., 2014) e ocasiona a ocupação desordenada do espaço.

As estradas não oficiais definem uma nova dinâmica de ocupação na Amazônia Legal. Os atores locais constroem milhares de quilômetros de estradas ilegais em terras públicas. Essas vias também facilitam a grilagem, o desmatamento, as queimadas e a exploração predatória de madeira, além de ampliar os conflitos pela posse da terra (Souza et al., 2005).

A proporção do desmatamento como função da distância das estradas na Amazônia legal tem, normalmente, padrões de variações exponenciais; grande proporção de desmatamento acontece próximo às estradas. Ferreira (2001) encontrou curvas exponenciais do desmatamento em função da distância das estradas e Nepstad et al. (2001) demonstraram que três quartos dos desmatamentos entre 1978 e 1994 ocorreram dentro de uma faixa de 100 km de largura ao longo das rodovias BR 010 (Belém-Brasília), BR 364 (Cuiabá-Porto Velho) 
e PA 150 (Laurance et al., 2004).

\subsubsection{Características da Exploração Madeireira na Amazônia Legal}

A exploração da madeira ainda é uma das bases da economia em alguns estados da Amazônia Legal (especialmente no Pará, em Mato Grosso e em Rondônia), e organiza-se em um sistema bastante complexo, que alia processos tradicionais aos modos mais agressivos de extração (Arco, 2005).

As madeireiras instaladas na Amazônia Legal extraem e processam mais de 300 espécies madeireiras (Barros \& Uhl, 2002 apud Martini et al., 1994). Existem três padrões distintos de exploração madeireira em terra firme: (i) em fronteiras antigas, onde existe infraestrutura estabelecida; (ii) em fronteiras recentes, onde a infraestrutura é precária e a exploração é menos intensiva; e (iii) em fronteiras incipientes, onde os madeireiros são os encarregados por estabelecer a infraestrutura (Barros \& Uhl, 2002). Na floresta de várzea, há a fronteira estuarina (SFB \& Imazon, 2010). A fronteira antiga tem mais de 30 anos de idade, e lá a floresta é aberta, de transição (sul) e densa (norte); os principais polos em tais fronteiras são Sinop e Feliz Natal (Mato Grosso), Paragominas e Tailândia (Pará). A fronteira intermediária tem entre 10 e 30 anos, o tipo de floresta é aberto (sul) e densa (norte); os principais polos em tais fronteiras são Cláudia e Marcelândia (Mato Grosso), Cujubim e Machadinho do Oeste (Rondônia) e Rio Branco (Acre). A fronteira nova tem menos de 10 anos, o tipo de floresta é denso e os principais polos são Castelo de Sonho (Pará), Aripuanã e Colniza (Mato Grosso). Já a fronteira estuaria tem mais de 300 anos de idade, sua floresta é de várzea e os principais polos são Belém, Breves e Pontel (Pará) (SFB \& Imazon, 2010).

As principais características do setor madeireiro na região são a diversidade de atores envolvidos e as várias estratégias utilizadas na extração, transporte de toras e processamento. As equipes de extração trabalham em regiões de várzea ou de terra firme. $\mathrm{O}$ transporte das toras se dá em jangadas (em áreas de várzea), balsas ou caminhões. As serrarias podem ser indústrias familiares rudimentares, de porte médio com serras de fita, ou grandes fábricas de laminados e compensados (Barros \& Uhl, 2002). Na Amazônia Legal, os estabelecimentos que realizam o processamento da madeira nativa após sua extração na floresta classificam-se em: microsserrarias, serrarias, beneficiadoras, laminadoras e fábricas de painéis (SBF \& Imazon, 2010).

A exploração da madeira na Amazônia Legal é um vetor de degradação da floresta e é, em sua maior parte, realizada ilegalmente, exercendo forte pressão sobre Unidades de 
Conservação, Territórios Indígenas e mesmo propriedades particulares. É importante observar que embora o corte seletivo para extração madeireira não acarrete em uma mudança imediata de uso do solo, essa prática geralmente pode levar ao desmatamento (Davidson et al., 2012). Na Amazônia Legal, no primeiro estágio da exploração madeireira, há ocorrência da retirada das madeiras mais nobres, seguidas das madeiras para a construção civil e, finalmente, das árvores de madeiras leves remanescentes, para a produção de compensados e placas (SBF \& IMAZON, 2010). Neste momento, em que foi eliminado cerca de 50\% do dossel, permanecem em pé poucas árvores que não têm valor comercial, como as palmeiras (MCT \& INPE, 2008), caracterizando áreas em que tal dinâmica ocorre como áreas degradadas. É prática comum a introdução de capim em tais áreas degradadas - com isto, atividades pecuárias podem se desenvolver. O capim e a cobertura florestal remanescente são queimados posteriormente, provocando uma segunda limpeza da área. Com a recorrência do fogo, sobram apenas cerca de $10 \%$ a $20 \%$ das árvores que compõem o dossel e uma grande quantidade de árvores mortas em pé (MCT \& INPE, 2008). Queimadas subsequentes destroem completamente o que restou da floresta inicial (desmatamento). Este processo de degradação, ilustrado na Figura 5, em que a pastagem é gradativamente introduzida, pode durar anos.

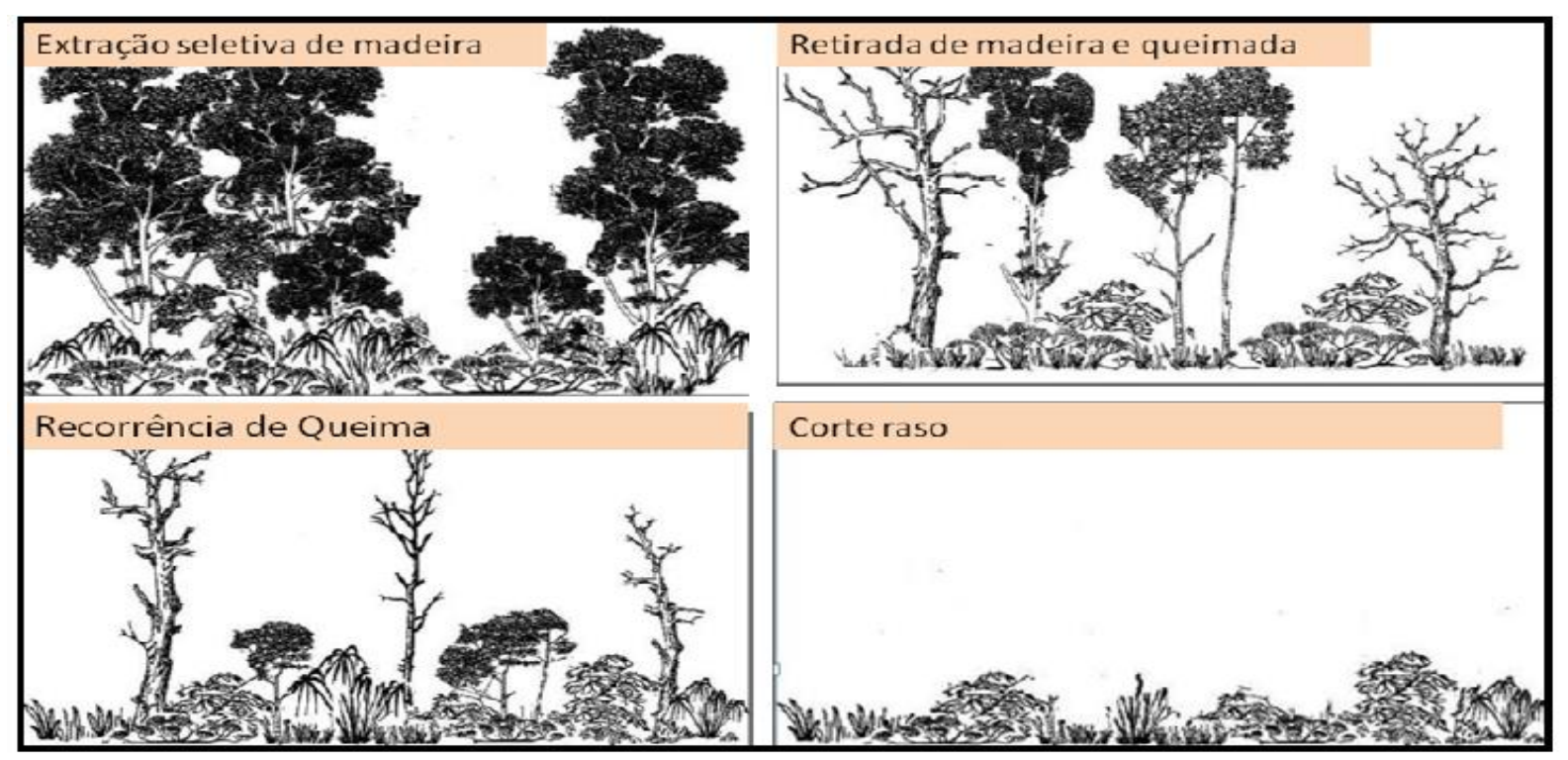

Figura 5: Ilustração da degradação progressiva que resulta em desmatamento (corte raso). Fonte: INPE, 2008 apud Barlow \& Peres, 2008.

A gestão das florestas no Brasil envolve diferentes instituições e os três níveis de governo (federal, estadual e municipal). $\mathrm{O}$ arranjo institucional para a gestão florestal nas diversas esferas se dá como segue: (i) a responsabilidade da Política Florestal na União é do MMA, nos Estados é da Secretaria Estadual de Meio Ambiente e nos Municípios é da 
Secretaria Municipal de Meio Ambiente; (ii) O Controle e Fiscalização Ambiental das Florestas é de responsabilidade do IBAMA na União, do Órgão Estadual ou Secretaria de Meio Ambiente nos Estados e Órgão Municipal ou Secretaria de Meio Ambiente nos Municípios; (iii) a Conservação Florestal é de responsabilidade do ICMBio a nível Federal, e do Órgão Estadual e Municipal de Meio Ambiente nos Estados e Municípios, respectivamente; (iv) a Gestão de Florestas Públicas e Concessões Florestais é de responsabilidade do Serviço Florestal Brasileiro a nível Federal e do Órgão Estadual de Gestão de Florestas Públicas a nível Estadual; (v) os Órgãos Colegiados de Participação na Gestão Florestal são: CONAMA, CONAFLOR e CGFLOP na União, Conselho Estadual de Meio Ambiente a nível Estadual e Conselho Municipal de Meio Ambiente a nível Municipal.

Há, também, participação social no processo decisório da gestão florestal através de três órgãos colegiados: (i) O Conselho Nacional do Meio Ambiente (Conama); (ii) A Comissão Nacional de Florestas (Conaflor), que fornece diretrizes para a implementação das ações do Programa Nacional de Florestas e permite articular a participação dos diversos grupos de interesse no desenvolvimento das políticas públicas do setor florestal brasileiro; e (iii) A Comissão de Gestão de Florestas Públicas (CGFLOP), que é o órgão de natureza consultiva do Serviço Florestal Brasileiro e tem a finalidade de assessorar, avaliar e propor diretrizes para gestão de florestas públicas brasileiras, além de manifestar-se sobre o Plano Anual de Outorga Florestal (MMA \& SBF, 2013).

Informações sobre o setor florestal podem ser obtidas através do Sistema Nacional de Informações Florestais (SNIF), que é uma base de dados constituída por meio da obtenção, produção, tratamento, organização, armazenamento, processamento e disseminação de dados, informações e conhecimentos relacionados ao tema florestal (www.florestal.gov.br). É competência do Serviço Florestal Brasileiro criar e manter o SNIF (Brasil, 2006). Seus principais eixos de informações são: Recursos Florestais (informações providas por diversas instituições e pelo Inventário Florestal Nacional - IFN), Gestão Florestal (informações providas pelos órgãos do Sisnama), Produção Florestal (informações produzidas pelo setor florestal e instituições federais, incluindo extração, produção, consumo e mercado) e Educação e Pesquisa Florestal (informações produzidas por instituições de ensino e pesquisa florestal). O SNIF tem como meta se transformar na principal plataforma de disponibilização de dados e informações florestais, em formatos apropriados aos tomadores de decisão e diferentes públicos da sociedade, em diversas escalas e aplicações, de modo a subsidiar o uso sustentável, a conservação e a recuperação das florestas do Brasil (MMA \& SBF, 2013). 


\subsubsection{A Questão Fundiária na Amazônia Legal e os Processos de Ocupação Ilegal de Terras}

Até meados de 1960, quase a totalidade das terras da Amazônia Legal era constituída por terras públicas e livres de titulação como propriedade privada (Loureiro \& Pinto, 2005). Com o novo modelo de desenvolvimento para a região - posto em prática durante a ditadura militar - inúmeras vantagens fiscais foram oferecidas a grandes empresários e grupos econômicos que desejassem investir em empreendimentos que viessem a se instalar na região. Muitos empresários não investiram os recursos em novas empresas na região, mas sim na compra de terras para simples especulação futura (muitos convertendo as áreas de florestas em pastos para criação de gado). Assim, nos anos setenta e oitenta, terras públicas - habitadas secularmente por comunidades tradicionais - foram vendidas em lotes de grandes dimensões para novos investidores, e era frequente que as terras adquiridas fossem demarcadas pelos novos proprietários em uma extensão muito maior do que a dos lotes que originalmente haviam adquirido (Loureiro \& Aragão, 2005).

Tornaram-se comuns práticas objetivando a grilagem de terras, que ainda estão em curso atualmente, tais como: a venda de uma mesma terra a diversos compradores; a revenda de títulos de terras públicas a terceiros; a confecção ou adulteração de títulos de propriedade e certidões diversas; a incorporação de terra pública a terras particulares; a venda de títulos de terra atribuídos a áreas que não correspondem aos mesmos; o remembramento de terras às margens das grandes estradas federais, que em anos anteriores haviam sido distribuídas em pequenos lotes para fins de reforma agrária; e ainda, mais recentemente, a venda de terra pública pela internet como se os vendedores fossem seus reais proprietários, com base em documentação forjada (Loureiro \& Pinto, 2005).

A maior parte da terra grilada transforma-se em situações consolidadas; as terras apropriadas ilegalmente se tornam um patrimônio privado, pois os imóveis são comercializados informalmente ou no mercado formal com a utilização de documentos falsos - a área privatizada gratuitamente e ilegalmente na região é enorme (Loureiro \& Pinto, 2005; Barreto et al., 2008).

O desmatamento é consequência de interações estratégicas entre proprietários de terras e posseiros. Proprietários de terras desmatam determinadas áreas preventivamente, para indicar que as terras estão sendo utilizadas e assegurar a propriedade e reduzir os riscos de expropriação de tais áreas. Os posseiros invadem terrenos, desmatam estas áreas e podem, posteriormente, ganhar reconhecimento oficial de posse de terra, com títulos de propriedades 
formais. Na Amazônia Legal, a insegurança relacionada aos direitos de propriedade vem ocasionando conflitos violentos e aumento de desmatamento (Araújo et al. 2009).

\subsection{IMPACTOS DOS PROCESSOS DE DESMATAMENTO E DEGRADAÇÃO FLORESTAL}

Os processos de desmatamento e degradação florestal ocorridos na Amazônia Legal acarretam importantes impactos negativos em âmbito social, cultural e ecológico. Entre os impactos sociais e culturais, vale ressaltar a marginalização dos povos indígenas e de comunidades tradicionais, endemia de doenças e concentração fundiária (Prates, 2008), e o surgimento de tensões entre autoridades ambientais e agentes de desmatamento e degradação florestal, propagando conflitos violentos na região (http://www.worldwatch.org). Além disso, deve-se levar em consideração que comunidades que habitam áreas com ampla cobertura florestal tendem a ser mais pobres e a ter maiores graus de dependência dos recursos florestais para sua subsistência. Em muitos casos, os benefícios econômicos das atividades que ocasionam desmatamento e degradação florestal tendem a ser capturados por companhias de média ou larga escala e por elites, aumentando a desigualdade social (Rautner, Leggett \& Davis, 2013). As atividades econômicas que caracterizam o atual processo de ocupação e desmatamentos não fazem um uso socialmente ótimo da rica base de recursos naturais (Margulis, 2003).

\subsubsection{Características dos Impactos do Desmatamento e Degradação Florestal em Âmbito Ecológico}

Diversos impactos ambientais são associados às mudanças de uso do solo e processos de degradação florestal na Amazônia Legal. Um dos impactos mais relevantes é a fragmentação florestal, que resulta de processos de degradação e desmatamento. Tal processo torna a vida selvagem mais vulnerável e ocasiona a mortalidade adicional de árvores, ocasionando mudanças na composição das espécies animais e vegetais, o que leva à redução de diversidade, alteração de microclimas e maiores emissões de carbono para a atmosfera (Broadbent et al., 2008; Laurance, 2001). O processo torna também o interior da floresta mais acessível para atividades exploratórias e para a expansão de atividades agropecuárias (Broadbent et al., 2008). Os fragmentos florestais são altamente sensíveis às atividades desenvolvidas em seus entornos. Na Amazônia Legal, os efeitos da fragmentação estão passíveis a interações sinergéticas com ameaças antropogênicas (especialmente incêndios florestais), mas é possível que ocorra a recuperação de paisagens fragmentadas, desde que 
protegidas de tais ameaças, em uma ou duas décadas (Laurance et al., 2010). Florestas secundárias podem se desenvolver rapidamente, desde que as condições do solo não se encontrem deterioradas por queimadas sucessivas (Laurance et al., 2010; Norden et al., 2010) e atividades antropogênicas não perturbem a região em recomposição.

No entanto, Feedbacks positivos entre secas, incêndios florestais e atividades econômicas apresentam grande potencial para causar impactos em grandes áreas da floresta Amazônica. A morte de árvores induzida pelas secas pode aumentar a vulnerabilidade a distúrbios relacionados aos incêndios florestais (Brando et al. 2008), já que cada árvore morta abre uma clareira pela qual a energia de radiação penetra na floresta, aumentando a temperatura no seu interior e, consequentemente, o risco de incêndios. Estudos de campo envolvendo incêndios florestais experimentais indicam que a vulnerabilidade das florestas ao fogo é inversamente proporcional à densidade e altura média da folhagem (Ray et al. 2005).

Incêndios florestais podem, então, aumentar a vulnerabilidade para queimadas futuras em um feedback positivo através da morte de árvores, abertura no dossel e aumento de penetração solar no interior da floresta (Nepstad et al. 2008). Baseando-se em resultados de um experimento com regimes de incêndios anuais e trienais na Amazônia Legal, Brando et al. (2008) demonstraram o aumento abrupto da mortalidade de árvores (226\% quando analisado o regime anual; $462 \%$ quando analisado o regime trienal) durante um evento de seca severa, quando as temperaturas do ar e as cargas de combustível se apresentavam em níveis substancialmente mais elevados e a umidade relativa se encontrava em níveis abaixo da média. Isso ocasionou a redução do dossel (23\% - regime anual; $31 \%$ - regime trienal) e biomassa viva sobre o solo (12\% - regime anual; $30 \%$ - regime trienal) e favorecendo a invasão descontrolada de gramíneas inflamáveis ao longo das áreas de borda da floresta (80\% - regime anual; 63\% - regime trienal), onde os incêndios foram mais intensos. Evidencia-se que eventos de seca combinados com a fragmentação florestal e fontes combustíveis antropogênicas vêm causando a mortalidade de árvores e degradação florestal de maneira amplamente difundida (Brando et al., 2008). Prevê-se que a Amazônia poderá estar exposta a secas mais intensas ao longo do século XXI (Cox et al., 2004; Lima et al., 2012), o que, combinado com os processos de desmatamento e degradação florestal, poderá levar ao aumento de incêndios florestais na região e agravamento de seus impactos.

As grandes emissões de gases e partículas provenientes dos incêndios florestais, tanto de áreas de pastagem quanto de floresta primária, são responsáveis por emissões significativas de gases traço e partículas de aerossóis para a atmosfera (Artaxo et al., 2005, 1998, 2002, 
2003). Tais emissões afetam os mecanismos naturais de diversos processos atmosféricos na região, tais como a supressão da formação de nuvens e consequente diminuição da eficiência do processo de precipitação. Além disso, os incêndios florestais ocasionam a emissão de diferentes GEE para a atmosfera, como $\mathrm{CO}_{2}(\mathrm{~m}), \mathrm{CH}_{4}$ (metano) e $\mathrm{N}_{2} \mathrm{O}$ (óxido nitroso) (Liousse et al., 2004) e de CO (monóxido de carbono), $\mathrm{NO}_{2}$ (dióxido de nitrogênio), HCNM (hidrocarbonetos não metano), cloreto e brometo de metila, compostos orgânicos voláteis (COVs) e outros gases (Andreae et al., 2002).

Além disso, destaca-se que a formação de ozônio na atmosfera resulta principalmente da interação entre óxidos de nitrogênio (NOx) e COVs (Orlando, 2008). Tais gases são emitidos durante incêndios florestais, o que leva ao aumento das concentrações de ozônio a níveis que podem ocasionar impactos à floresta, causando danos aos estômatos das folhas, devido às propriedades fitotóxicas de tal gás (Artaxo et al., 2005). Devido às propriedades óticas das partículas emitidas em incêndios florestais (Guyon et al., 2004), estes também têm efeitos importantes no balanço de radiação atmosférico, atenuando até $70 \%$ da radiação incidente, afetando o funcionamento do ecossistema amazônico (Eck et al., 2003; Kaufman et al., 1998). A conversão de florestas com o uso de fogo leva ao aumento de albedo e redução de fluxo de vapor de água (Nepstad et al., 2001).

Ressalta-se que alguns modelos que integram clima e vegetação sugerem que a remoção de $30-40 \%$ das áreas de floresta pode levar a um regime de clima permanentemente mais seco na Amazônia (Malhi et al. 2008; Oyama et al. 2003). Porém, deficiências na estrutura e aplicação dos modelos climáticos sugerem que as incertezas das simulações climáticas apresentadas são muito grandes (Davidson et al. 2012). A quantificação das emissões de GEE derivadas dos processos de desmatamento, queimadas e decomposição da biomassa florestal são consideradas como um dos componentes mais incertos do ciclo global de carbono (Aguiar et al. 2012). Apesar de tais incertezas, é inegável que a interação entre remoção de vegetação e alterações climáticas é significativa, com impactos regionais e globais, através de alteração do balanço hídrico e maiores emissões de GEE, já que grande parte da biomassa das árvores (galhos, tocos e raízes) removidas se decompõem (Fearnside, 2003; Fearnside, 1995a). Também deve-se atentar para o risco de extinção de espécies florestais. Algumas espécies florestais ameaçadas de extinção são: Cerejeira (Amburana cearensis var. acreana, Fabaceae); Pau-roxo (Peltogyne maranhensis, Fabaceae); Castanheira (Bertholletia excelsa, Lecythidaceae); Mogno (Swietenia macrophylla, Meliaceae); Pauamarelo (Euxylophora paraenses, Rutaceae) (MMA \& SBF, 2013), entre muitas outras. 
Vale ainda ressaltar que os processos de desmatamento e degradação florestal ocasionam: (i) a degradação e o empobrecimento do ecossistema aquático; (ii) o aumento da temperatura dos cursos d'água em até $4 \mathrm{C}$ e a obstrução da conectividade dos mesmos ocasionados por represamentos; e (iii) mudanças no fluxo dos corpos d'água e em sua bioquímica (Cavalett \& Ortega, 2009). No caso da produção de soja, especificamente, destaca-se que esta atividade é altamente dependente de recursos não-renováveis, como combustíveis fósseis, e requer grandes quantidades de energia elétrica, fertilizantes químicos, pesticidas, herbicidas e sementes híbridas. Os impactos do modelo de produção de soja atual englobam a redução da fertilidade do solo, a intoxicação de pessoas e animais por agrotóxicos, a expulsão de pequenos fazendeiros de suas terras, a contaminação do solo e de corpos d'água e lençóis freáticos, erosão do solo e perda de biodiversidade (Cavalett \& Ortega, 2009). No entanto, ressalta-se que alguns esforços vêm sendo colocados em prática para reduzir tais impactos, como a prática de plantio direto, que vem se tornando mais frequente no Brasil. Tal prática permite a redução da erosão do solo e do uso de pesticidas, fungicidas e outros agentes químicos, além de ocasionar a redução da perda de carbono do solo e do distúrbio no balanço energético ocasionado pelo aumento do albedo (Cavalett \& Ortega, 2009).

As práticas de redução de impactos oriundos de processos de desmatamento e degradação florestal devem ser ampliadas. Nesse contexto, o monitoramento das dinâmicas de uso do solo e combate às práticas ilegais são fundamentais. No Capítulo seguinte, instrumentos de monitoramento e de controle do desmatamento serão detalhados. 


\section{CAPÍtUlo 2 - MONITORAMENTO E MEDIDAS DE CONTROLE DE PROCESSOS DE DESMATAMENTO NA AMAZÔNIA LEGAL}

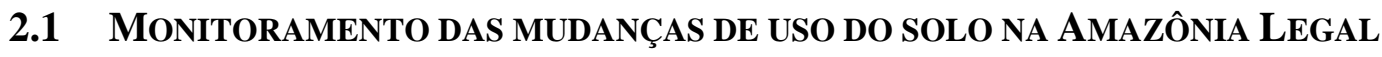

O mapeamento e monitoramento das mudanças de cobertura do solo na Amazônia Legal são atividades complexas devido à extensão da região, que além de estar frequentemente encoberta por nuvens, está sujeita a rápidas mudanças. $\mathrm{O}$ estudo das mudanças de uso do solo vem sendo realizado com o auxílio de sensoriamento remoto por satélites e censos agropecuários periódicos, que auxiliam na construção das variações espaciais e temporais do desmatamento.

O uso do solo na região Amazônica tem sido mapeado através do uso de satélites desde 1970. As primeiras investigações sobre desmatamento objetivavam verificar se os recursos destinados ao desenvolvimento da Amazônia estavam sendo empregados apropriadamente (Valeriano, 2014). Tais investigações foram conduzidas pela Superintendência de Desenvolvimento da Amazônia (SUDAM), e tinham como foco monitorar o eixo Belém-Brasília. Posteriormente, o Instituto Brasileiro de Desenvolvimento Florestal (IBDF) requisitou o mapeamento do território total da Amazônia Legal, e em 1979 foi gerado o primeiro mapa de desmatamento da região. Após tal feito, a equipe IBDF se dispersou e o monitoramento da região foi paralisada (Valeriano, 2014).

No entanto, quando as pressões nacionais e internacionais para redução de desmatamento e degradação florestal, começaram a ganhar força no final da década de 80, o governo brasileiro recorreu ao Instituto Nacional de Pesquisas Espaciais (INPE) para desenhar um novo programa de monitoramento do desmatamento na Amazônia; assim nasceu o Sistema PRODES, em 1988 (Valeriano, 2014).

Atualmente, o Programa de Monitoramento da Amazônia por Sensoriamento Remoto do INPE conta com quatro sistemas operacionais e complementares: PRODES, QUEIMADAS, DETER e DEGRAD, detalhados abaixo:

\section{PRODES - Projeto de Monitoramento do Desmatamento na Amazônia Legal} por Satélite.

- Sistema de detecção de desmatamentos com cálculo anual da taxa de desmatamento na Amazônia. Não registra as derrubadas parciais da floresta resultantes de queimadas e de extração seletiva de madeira (www.obt.inpe.br/prodes/).

- São utilizadas imagens dos sensores Landsat e CBERS com resoluções de 30 e 20 metros. Área mínima mapeada de 6,25ha (www.obt.inpe.br/prodes/). 
O PRODES fornece dados de desmatamento de corte raso verificados entre $1^{\circ}$ de agosto de um ano a 31 de julho do ano seguinte. Tais dados são insuficientes para ações de prevenção e de fiscalização, devido ao tempo que levam para ser produzidos e por incluir apenas as áreas de corte raso (INPE, 2008). Assim, em 2004 o INPE implementou o Sistema de Detecção de Desmatamento em Tempo Real (DETER) para monitoramento contínuo do desmatamento e da degradação florestal. O sistema foi criado no âmbito do Plano de Ação para a Prevenção e Controle do Desmatamento na Amazônia Legal (PPCDAm) do Governo Federal, iniciado em 2003. Além disso, foi criado o sistema DEGRAD, para mapeamento individual de áreas degradadas.

\section{DETER - Sistema de Detecção de Desmatamento em Tempo Real.}

- Sistema de detecção de desmatamentos em tempo quase real no qual os dados produzidos pelos INPE são repassados ao IBAMA de 15 em 15 dias, aproximadamente. As informações geradas servem à produção de documentos indicativos de novas áreas de desmatadas pelo Centro de Monitoramento Ambiental do IBAMA (www.obt.inpe.br/deter/).

- Baseado no sensor MODIS a bordo dos satélites TERRA e AQUA, com temporalidade diária. Área mínima mapeada é de 25ha (www.obt.inpe.br/deter/).

\section{DEGRAD - Mapeamento da Degradação Florestal na Amazônia Brasileira}

- Mapeamento de áreas em processo de desmatamento em imagens LANDSAT e CBERS, onde a cobertura florestal ainda não foi totalmente removida. O processo consiste em preparar as imagens de satélite, aplicando realces de contraste de modo a destacar as evidências da degradação. As áreas degradadas são então mapeadas individualmente. (www.obt.inpe.br/degrad/).

- Assim como o PRODES, a área mínima mapeada pelo DEGRAD é de 6,25 hectares (www.obt.inpe.br/degrad/).

Adicionalmente, o INPE mantém desde 1985 um sistema operacional de monitoramento de queimadas por satélite.

\section{QUEIMADAS}

- Identificação de focos de calor em imagens de satélites de baixa resolução espacial, como os da série NOAA, e os satélites GOES, TERRA, AQUA e METEOSAT (www.inpe.br/queimadas/). 
A Figura 6 apresenta a tendência histórica de taxas de desmatamento na Amazônia registrada pelo Sistema PRODES do INPE. Nesta Figura, observa-se a expressiva redução das taxas de desmatamento anuais a partir do ano de 2005. No ano de 2007, a taxa de desmatamento reduziu-se a quase metade daquela observada no período que compreende os anos 1998-2006, sendo o registro para esse ano de $11.000 \mathrm{~km}^{2}$ de área desmatada (Nepstad et al., 2006).

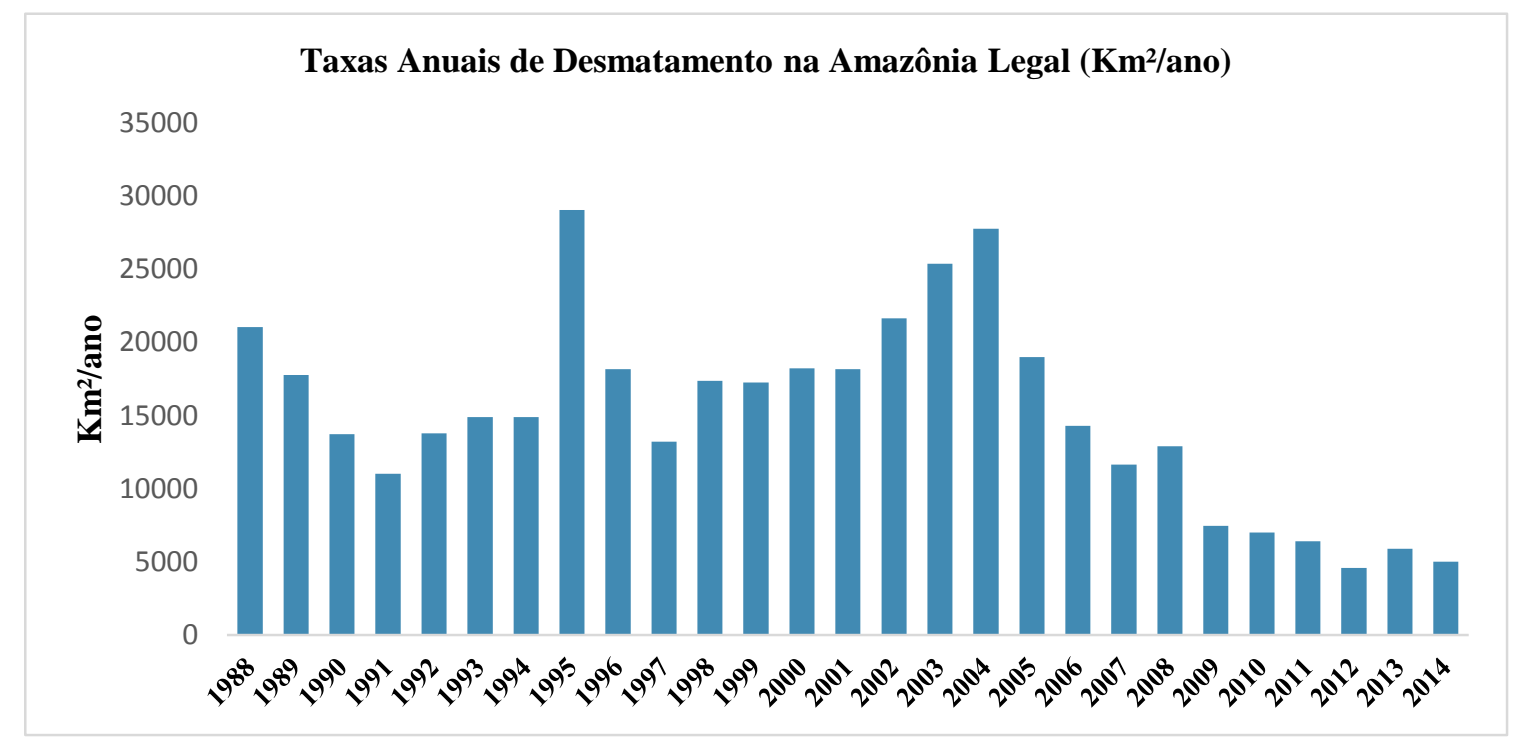

Figura 6: Taxas anuais de desmatamento na Amazônia Legal em $\mathrm{Km}^{2} / \mathrm{ano}$, registradas pelo Sistema PRODES do INPE. Fonte: INPE-PRODES, 2014.

Nas Figuras 7 e 8, observa-se como a redução das taxas de desmatamento foi distribuída em cada estado da Amazônia Legal. Na Figura 8, é possível observar com maior detalhe como tal distribuição ocorreu nos estados que apresentam menores taxas de desmatamento. Verificam-se reduções expressivas principalmente nos estados de Mato Grosso, Pará e Rondônia.

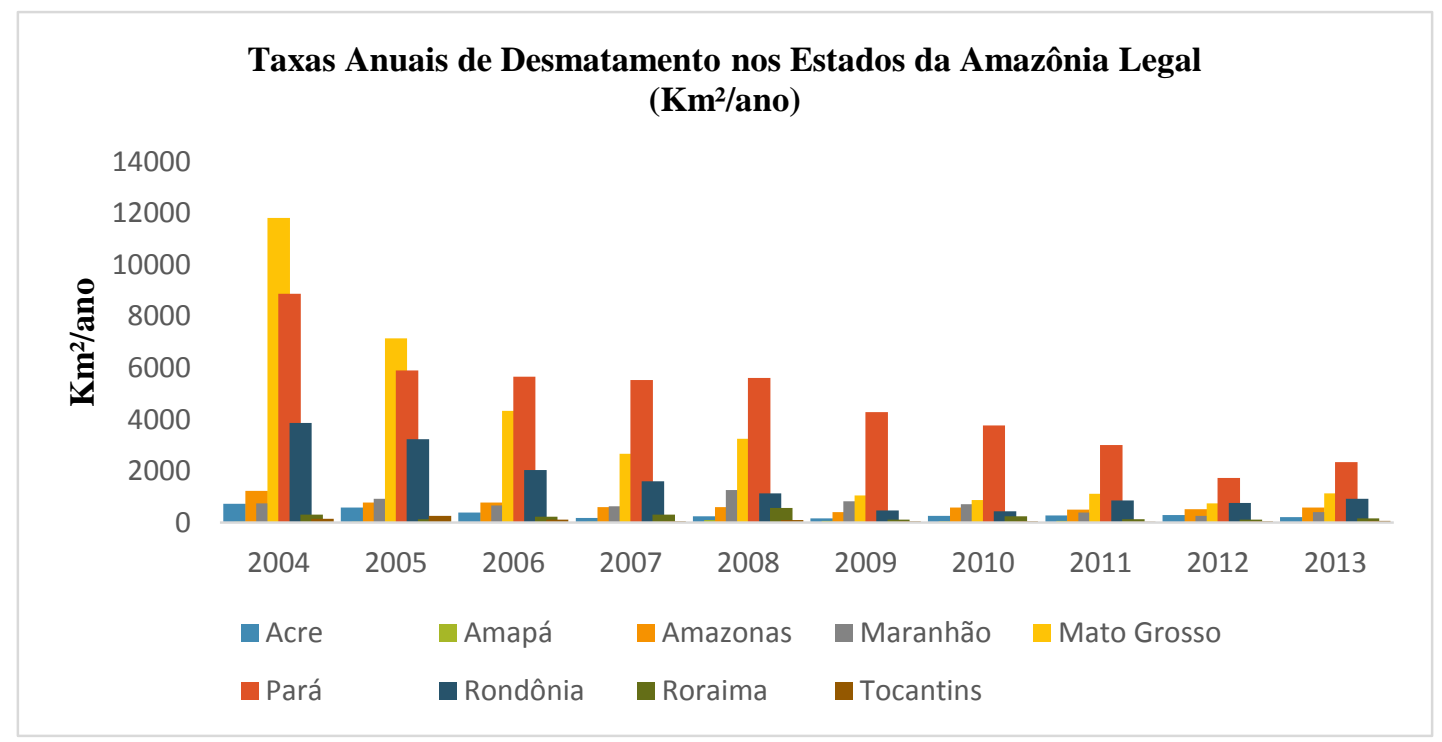

Figura 7: Taxas anuais de desmatamento nos estados da Amazônia Legal, entre 2004 e 2013 em $\mathrm{Km}^{2} /$ ano. Fonte: INPE-PRODES, 2014. 


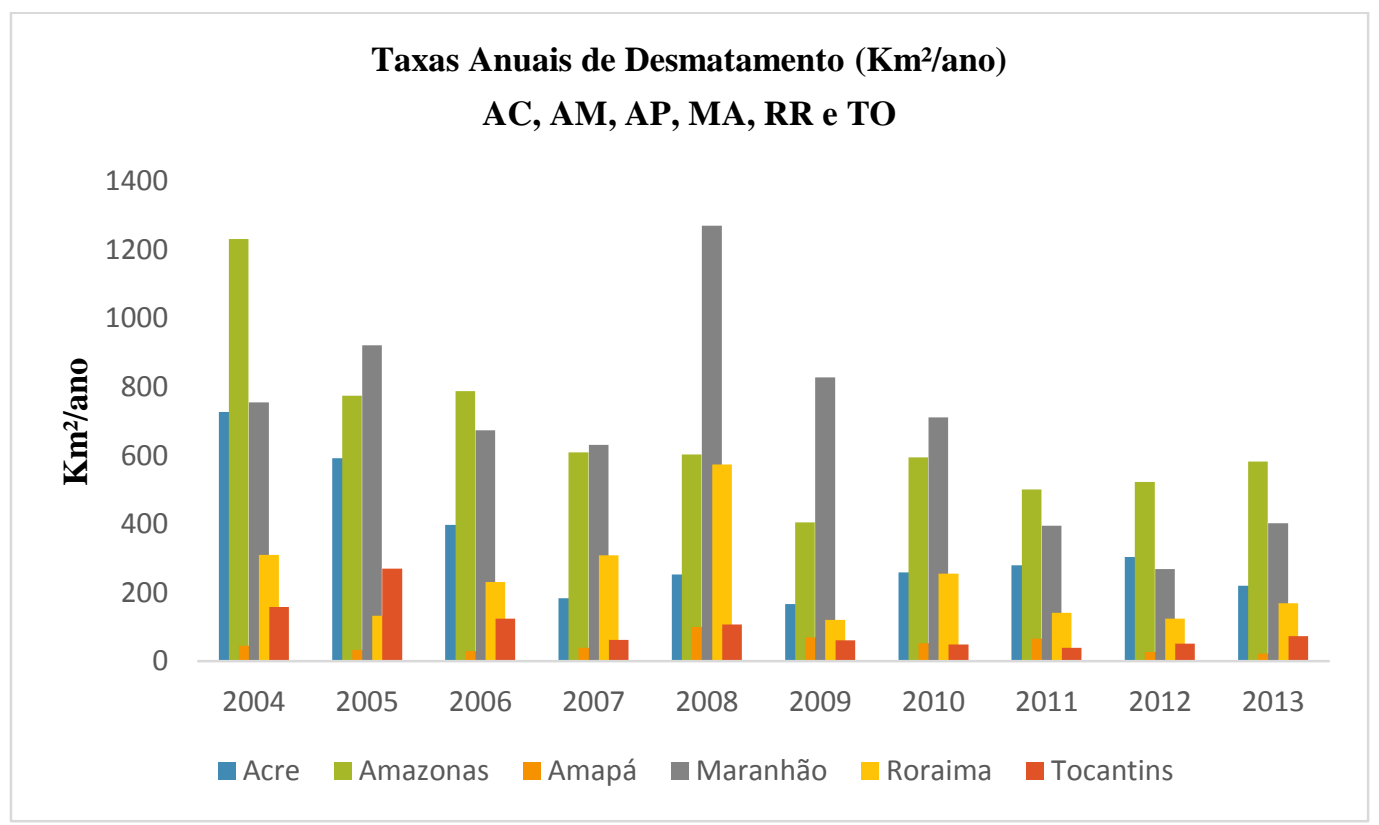

Figura 8: Taxas Anuais de Desmatamento nos Estados que Apresentam menores Taxas de Desmatamento, entre 2004 e 2013 em Km²/ano. Fonte: INPE-PRODES, 2014.

Com a redução de desmatamento entre 2005 e 2013, houve redução da emissão de $\mathrm{CO}_{2}$ para a atmosfera. A estimativa de tal redução, ano a ano, é ilustrada na Figura 9. As estimativas de $1^{\text {a }}$ Ordem supõem, de modo simplificado, que $100 \%$ das emissões ocorrem no momento da mudança da cobertura do solo. As chamadas estimativas de $2^{\mathrm{a}}$ Ordem buscam representar o processo gradativo de liberação e absorção do carbono, como ocorre de fato.

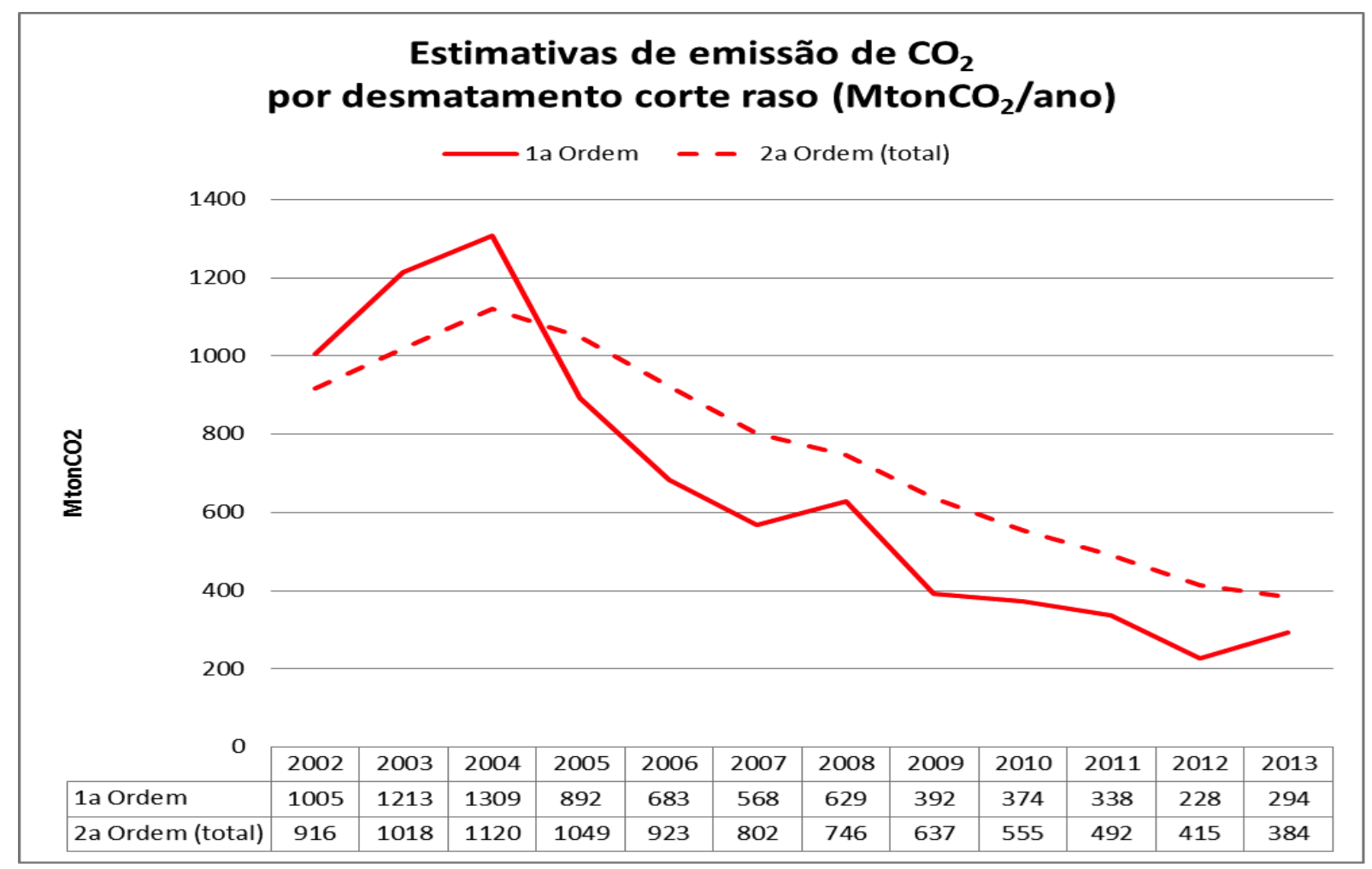

Figura 9: Estimativa de emissões de CO2 resultantes de processos de desmatamento. Fonte: Aguiar, 2012. 
Observa-se redução expressiva das emissões de $\mathrm{CO}_{2}$ estimadas a partir de 2005. Em relação às emissões de $\mathrm{CO}_{2}$ estimadas para o ano de 2004, em 2013 as emissões de $1^{\mathrm{a}}$ Ordem sofreram redução de 78,\% e as emissões de $2^{\mathrm{a}}$ Ordem sofreram redução de $68 \%$.

A seguir, serão detalhados os mecanismos empregados para redução de desmatamento na Amazônia.

\subsection{Medidas De ConTrole AO PROCESSO DE DESMATAMENTO}

A preocupação com as altas taxas de desmatamento na Amazônia Legal tem suas raízes nos impactos da Constituição Federal de 1988 e em críticas ao modelo de desenvolvimento da região que estavam em curso durante o regime militar - tais foram as bases para a formulação de novas políticas para o desenvolvimento sustentável da região (Hetch, 2011).

Tal processo envolveu quatro tendências. A primeira delas foi a globalização de discursos ambientais/ecológicos que estavam associados com o surgimento do movimento ambientalista nos Estados Unidos nos anos setenta - e que posteriormente foi internacionalizado via organizações conservacionistas e agências de desenvolvimento multilaterais. A segunda tendência foi a expansão das pesquisas científicas de cunho ambiental direcionadas aos trópicos do planeta. A terceira, como consequência desta segunda, foi a de tornar os conhecimentos tradicionais indígenas, a ecologia cultual, a agroecologia e o "desenvolvimento alternativo" uma ciência. A quarta tendência foi o surgimento de estudos climáticos que sustentaram a inquietação em torno de dinâmicas de desmatamento no final dos anos oitenta (Hetch, 2011). Tais tendências forneceram subsídios científicos interdisciplinares para sustentar as políticas direcionadas à proteção da Amazônia Legal.

Além disso, novos atores nos movimentos socioambientais, preocupações de cunho social em torno da distribuição de terras e pesquisas de pequena e grande escala afetaram o desenvolvimento de debates sobre o desenvolvimento regional. Tais fatores ofereceram o arsenal intelectual necessário para fazer frente aos cálculos simplistas - baseados em fatores estritamente geopolíticos - de planejamento de desenvolvimento da região (Hetch, 2011). Também deve-se destacar que a importância crescente da sociedade civil aumentou o papel que as comunidades e ONGs tiveram nas novas políticas aplicadas à Amazônia Legal, especialmente após o assassinato de Chico Mendes, marco importante do conflito fundiário na Amazônia. 
Especialmente a partir do ano de 2003, observa-se um grande número de medidas que visam combater o desmatamento na região; tais medidas serão detalhadas a seguir.

\subsubsection{O Plano de Ação para Prevenção e Controle do Desmatamento na Amazônia Legal (PPCDAm)}

O Plano de Ação para Prevenção e Controle do Desmatamento na Amazônia Legal (PPCDAm) foi delineado a partir do estabelecimento, pelo Decreto Presidencial de 03 de Julho de 2003, de um Grupo Permanente de Trabalho Interministerial com a finalidade de propor medidas e coordenar ações que visem à redução dos índices de desmatamento na região. Sob a coordenação da Casa Civil da Presidência da República, o Grupo Permanente de Trabalho Interministerial foi composto com a participação dos seguintes órgãos: (i) Ministério da Agricultura, Pecuária e Abastecimento (MAPA); (ii) Ministério da Ciência e Tecnologia (MCT); (iii) Ministério da Defesa (MD); (iv) Ministério do Desenvolvimento Agrário (MDA); (v) Ministério do Desenvolvimento, Indústria e Comércio Exterior (MDIC); (vi) Ministério da Integração Nacional (MI); (vii) Ministério da Justiça (MJ); (viii) Ministério do Meio Ambiente (MMA); (ix) Ministério das Minas e Energia (MME); (x) Ministério dos Transportes (MT); e (xi) Ministério do Trabalho e Emprego (MTE). A partir do Decreto assinado em 15 de março de 2004, passaram a integrar o grupo o Ministério do Planejamento, Orçamento e Gestão e o Ministério das Relações Exteriores (PPCDAm, 2004). Até o presente momento, a implementação do PPCDAm se deu em três fases, detalhadas a seguir.

\subsubsection{PPCDAM FASE I (2004-2008)}

Com a criação do GT Interministerial sobre o Desmatamento na Amazônia, foi tomado como primeiro passo o estabelecimento de quatro subgrupos de trabalho para a elaboração de propostas estratégicas, detalhados na Tabela 1, abaixo:

\begin{tabular}{|c|c|c|}
\hline Subgrupo & Membros & Área de Atuação \\
\hline $\begin{array}{l}\text { Ordenamento } \\
\text { Fundiário e } \\
\text { Territorial }\end{array}$ & $\begin{array}{c}\text { SDS/MMA (coord.), SCA/MMA, } \\
\text { MDA, MAPA, MI, MDIC, MD, } \\
\text { MJ/FUNAI }\end{array}$ & $\begin{array}{l}\text { - Instrumentos de ordenamento } \\
\text { territorial com enfoque para política } \\
\text { fundiária, unidades de conservação e } \\
\text { estratégias de desenvolvimento local } \\
\text { sustentável. }\end{array}$ \\
\hline $\begin{array}{l}\text { Monitoramento e } \\
\text { Controle }\end{array}$ & $\begin{array}{l}\text { IBAMA/MMA (coord.), SCA/MMA, } \\
\text { MCT, MD, MJ, MTE, Casa Civil. }\end{array}$ & $\begin{array}{l}\text { - Instrumentos de monitoramento, } \\
\text { licenciamento e fiscalização de } \\
\text { desmatamento, queimadas e exploração } \\
\text { madeireira. }\end{array}$ \\
\hline Fomento a & SBF/MMA (coord.), SCA/MMA, & - Crédito Rural e Incentivos Fiscais. \\
\hline
\end{tabular}




\begin{tabular}{ccc}
\hline Atividades & MDIC, MAPA, MDA, MCT, MI, & - Assistência Técnica e Extensão Rural. \\
Sustentáveis & MTE, MF (convidado). & - Pesquisa Científica e Tecnológica. \\
Infraestrutura & SCA/MMA (coord.), MT, MME, MAPA, MI, & $\begin{array}{c}\text { - Políticas de infraestrutura, com ênfase } \\
\text { aos setores de transporte e energia. }\end{array}$ \\
\hline
\end{tabular}

Tabela 1: Subgrupos de Trabalho e Áreas de Atuação. Fonte: Adaptado de PPCDAm, 2004.

Nessa primeira fase do Plano, as medidas de combate ao desmatamento tiveram as seguintes diretrizes: (i) valorização da floresta para fins de conservação e uso sustentável; (ii) recuperação de áreas degradadas como forma de aumentar a produtividade e diminuir as pressões sobre as florestas remanescentes; (iii) ordenamento fundiário e territorial, priorizando o combate à grilagem de terras públicas, a criação de unidades de conservação e a homologação de terras indígenas; (iv) aprimoramento dos instrumentos de monitoramento, licenciamento e fiscalização do desmatamento; (v) fomento às atividades de uso sustentável dos recursos florestais e/ou uso intensivo de áreas agrícolas; (vi) gestão descentralizada e compartilhada de políticas públicas entre a União, estados e municípios; e (vii) participação ativa dos diferentes setores interessados da sociedade amazônica na gestão das políticas relacionadas à prevenção e controle do desmatamento (PPCDAm, 2004). O Plano Operacional foi idealizado no âmbito de cada subgrupo de trabalho e seus objetivos estão descritos conforme segue:

Monitoramento e Controle: (i) implantação do sistema DETER e (ii) intensificação das investigações (tendo como prioridade o respeito à integridade de Áreas Protegidas e ao cumprimento das exigências de Reserva Legal nas propriedades privadas) sobre crimes ambientais de maneira integrada, utilizando as informações disponíveis nos órgãos vinculados.

Ordenamento Territorial: (i) priorização das ações de ordenamento fundiário e territorial ao longo do Arco do Desmatamento, com destaque para a área de influência da BR163 (rodovia Santarém-Cuiabá); (ii) combate à grilagem de terras públicas; (iii) criação de novas UCs (tanto de uso sustentável, como de proteção integral) e a demarcação e homologação de terras indígenas; (iv) realização de zoneamento ecológico-econômico (ZEE) ao longo do Arco do Desmatamento e da área de influência da BR 163; (v) estabelecer nova política de reforma agrária, com promoção de desenvolvimento de atividades agrícolas em bases sustentáveis, alocando crédito, infraestrutura e assessoria técnica (PPCDAm, 2004).

Fomento a Atividades Sustentáveis: (i) definição de novas diretrizes e critérios para o uso sustentável dos recursos; e (ii) intensificação de programas de capacitação de mão de 
obra, com ênfase no manejo florestal e agricultura intensiva, esta última em áreas já desmatadas (PPCDAm, 2004).

Infra-Estrutura: coordenação do planejamento estratégico de obras de infraestrutura e as medidas preventivas, mitigadoras e compensatórias que devem ser executadas antes da realização da obra, com transparência e participação da sociedade (PPCDAm, 2004).

Com o objetivo de que a atuação do Plano fosse restringida para o campo mais diretamente vinculado ao problema central que propõe solucionar, houve a migração do componente "infraestrutura ambientalmente sustentável" para o Plano Amazônia Sustentável (PAS), já no primeiro ano de implementação do PPCDAm (PPCDAm, 2009). Desta forma, os subgrupos se estabeleceram como: Ordenamento Territorial; Monitoramento e Controle e Fomento a Atividades Sustentáveis.

Após quatro anos de sua implementação, novos fatos deixaram clara a necessidade de uma avaliação pormenorizada do Plano para indicar acertos e correções a serem feitas nas políticas de combate ao desmatamento. Para isso, no final de 2007, o Ministério do Meio Ambiente, por meio de cooperação técnica alemã, contratou consultoria independente que tinha como objetivo realizar uma avaliação da primeira fase de implementação do PPCDAm. Tal avaliação foi organizada e realizada pelo Engenheiro Agrônomo Guilherme C. Abdala e sua equipe, no ano de 2008. O foco do trabalho foi analisar a evolução, as dificuldades e as lições aprendidas após quatro anos do lançamento do PPCDAm, além de apontar questões a serem consideradas durante o processo de revisão para a segunda fase do Plano (Abdala, 2008). Para avaliação e revisão do PPCDAm, foram desenvolvidas as seguintes atividades: (i) levantamento e análises documentais; (ii) realização de entrevistas nos Ministérios e órgãos envolvidos com o Plano; (iii) realização de entrevistas com Governos Estaduais; e (iv) realização de entrevistas com ONGs e Movimentos sociais (Abdala, 2008).

Em relação à formulação do PPCDAm, a avaliação conduzida por Abdala (2008) apontou: (i) a falta de clareza e/ou detalhamento das relações que deveriam ser articuladas, ou que remetessem a um processo de articulação sistematizado, com grupos de interesse diversos, em especial os poderes públicos estaduais e municipais, representantes da iniciativa privada e organizações da sociedade civil; (ii) a projeção de várias ações de forma abrangente e generalizada, sem foco e/ou objetividade específicas, ou seja, sem conhecimento claro de particularidades ou peculiaridades sub-regionais e microrregionais, isto é, sem a projeção de geoestratégias; (iii) a dificuldade da coordenação central do Plano em prever os 
constrangimentos que se sucederam relacionados ao esforço multi-setorial, principalmente no quesito transversalidade.

A respeito do desempenho dos subgrupos durante os quatro anos de implementação do Plano, Abdala (2008) afirma que os subgrupos que o compõem apresentaram desempenhos diferenciados, assim verificados: (i) Subgrupo I - Ordenamento Fundiário: desempenho intermediário; (ii) Subgrupo II - Monitoramento e Controle: melhor desempenho; (iii) Subgrupo III - Fomento à Atividades Sustentáveis: desempenho baixo. O desequilíbrio no desempenho dos Subgrupos, durante os quatro anos decorridos, é um dos fatores determinantes que reduz a sustentabilidade e a efetividade das ações do PPCDAm.

As diretrizes para revisão do Plano para sua segunda fase foram sugeridas por Abdala (2008): (i) um desenho mais claro relacionando o objetivo superior (diminuição da taxa de desmatamento) e respectivas interações de causalidade, diretas ou indiretas, com ações e atividades propostas; (ii) a especificação clara de dimensões quantitativas, temporais e espaciais, ou seja, das metas relacionadas aos objetivos de projetos e, também, de objetivo(s) superior(es); (iii) uma padronização hierárquica do conjunto de subgrupos, ações e atividades, assim como do respectivo conjunto de indicadores; e (iv) a estruturação, para cada componente, das ações estratégicas e respectivos graus de prioridade, conforme teia de causalidade do desmatamento.

Abdala (2008) sugere, ainda, para uma conformação adequada do processo de planejamento, gestão e monitoramento do PPCDAm, a adoção da metodologia do Marco Lógico, devendo ser formulada em conjunto com Ministério do Planejamento; o mesmo consiste em um conjunto de conceitos inter-relacionados que definem as causas de uma intervenção (projeto), bem como o que deve ser feito (estratégia) para alcançar o resultado desejado (Abdala, 2008). Considerando o interesse de se estruturar o PPCDAm de forma a potencializar seu processo de monitoramento constante, entendeu-se como importante que, por meio do Marco Lógico, fossem estabelecidas: (i) uma Árvore de Problemas, consistindo em um sistema hierarquizado de relações causa-efeito de um problema original; (ii) uma Árvore de Objetivos ou Árvore de Soluções, construída a partir dessa cadeia de causalidade, para propor um conjunto de relações meios/fins como alternativas de solução para o problema original; e (iii) uma Matriz de Decisão, a partir da qual se passa ao planejamento da intervenção propriamente dita, com base nas alternativas de intervenção e as estratégias disponíveis conforme os potenciais, limitações e interesses da cada (Abdala, 2008). 
Do ponto de vista temático, Abdala (2008) afirma que os seguintes aspectos deveriam ser ressaltados para a revisão do Plano: (i) Sustentabilidade política do PPCDAm no médio e longo-prazos; (ii) Controle social e transparência; (iii) Descentralização, governança ambiental e protagonismo dos governos estaduais; (iv) Articulação com estratégias para redução das emissões de $\mathrm{CO}_{2}$; (v) Estratégia de responsabilização compartilhada pelo desmatamento e (vi) Foco em municípios prioritários.

A partir de avaliação dos pontos levantados e sugestões oferecidas por Abdala e sua equipe técnica, o modelo lógico do Plano foi apresentado e discutido com os secretários e representantes das secretarias de Meio Ambiente dos Estados da Amazônia Legal e com os representantes de organizações não governamentais (ONGs), em oficinas específicas. As sugestões, críticas e demandas foram avaliadas e foi elaborada, então, a segunda fase do PPCDAm.

\subsubsection{PРCDAM FASE II (2009-2011)}

Após os primeiros anos de implementação da primeira fase do PPCDAm, questões relacionadas às mudanças de uso do solo e desmatamento na Amazônia Legal apontaram sinais de mudança. Em relação à dinâmica do desmatamento em si, os grandes polígonos de desmatamento proeminentes nos anos anteriores passaram a diminuir sua participação no total do desmatamento, o que levou a um aumento relativo dos pequenos polígonos. Também, em 2007, os alertas mensais emitidos pelo Sistema DETER começaram a apontar uma retomada do aumento nas taxas do desmatamento. Em relação à gestão do problema, um ponto importante foi a descentralização da gestão florestal para os estados ocorrida em 2006, por meio da Lei de Gestão de Florestas Públicas, tornando ainda mais evidente a necessária integração de ações do Governo Federal com os Governos Estaduais. Destaca-se, também, o lançamento do Plano Nacional sobre Mudança do Clima (PNMC), trazendo metas quadrienais de redução do desmatamento na Amazônia.

A segunda fase do PPCDAm, então, refletiu tais mudanças, e as diretrizes incorporadas foram: (i) valorização da floresta para fins de conservação da biodiversidade, manejo florestal de produtos madeireiros e não madeireiros e a prestação de serviços ambientais; (ii) incentivos para a melhor utilização de áreas já desmatadas, contemplando inovação tecnológica e sistemas sustentáveis de produção; (iii) apoiar processos de certificação e valorização dos produtos da biodiversidade e de agregação de valor a esses produtos e a produtos oriundos de atividades locais; (iv) modelos alternativos de reforma 
agrária adequados à Amazônia, e a criação e consolidação de unidades de conservação e terras indígenas; (v) adoção de um estilo de gestão descentralizada e compartilhada de políticas públicas, por meio de parcerias entre a União, estados e municípios; (vi) estímulo à participação ativa dos diferentes setores da sociedade amazônica interessados na gestão das políticas relacionadas à prevenção e controle do desmatamento; (vii) incentivo à implementação do Cadastro Ambiental Rural (CAR); e (viii) dar visibilidade à realização das ações do Plano, por meio da divulgação das informações envolvendo as assessorias de comunicação dos Ministérios e da Presidência da República (PPCDAm, 2009). Entre as diversas iniciativas advindas da segunda fase do PPCDAm, destaca-se a intensificação das inspeções de campo por parte do IBAMA. Por exemplo, em duas das operações ocorridas em 2008 mais amplamente noticiadas, o IBAMA confiscou $20.000 \mathrm{~m}^{3}$ de madeira ilegal e 3000 cabeças de gado sendo criadas em Áreas Protegidas (Arima et al., 2014).

Percebe-se que grande parte das sugestões surgidas a partir da avaliação realizada sobre a primeira fase do PPCDAm por Abdala (2008) foram incorporadas na definição das diretrizes estratégicas que compõem a segunda fase do mesmo. Destaca-se que tais diretrizes foram elaboradas a partir da adoção da metodologia do Marco Lógico e que foram definidos um Plano Operativo que contempla "macro ações" e um Plano Operativo que contempla “ações complementares", refletindo a necessidade, apontada por Abdala (2008), de estruturação das ações estratégicas e definição de graus de prioridade. No PPCDAm Fase II encontra-se desenhada a Árvore de Problemas também sugerida, porém esta apresenta-se de forma ilegível.

Em 2010, o Ministério do Meio Ambiente (MMA) e a Comissão Executiva do PPCDAm detectaram a necessidade de realização de avaliação sobre a segunda fase do Plano. Assim, entre outubro de 2010 e julho de 2011, tal avaliação foi conduzida conjuntamente pelo Instituto de Pesquisa Econômica Aplicada (IPEA), a Comissão Econômica para a América Latina e Caribe (CEPAL) e a Cooperação Alemã para o Desenvolvimento, por meio da Deutsche Gesellschaft für Internationale Zusammenarbeit (GIZ). A avaliação apresentou, como recomendações referentes a aspectos gerais, os seguintes pontos: (i) manter a importância política do PPCDAm e uma coordenação de alto nível no âmbito do governo federal; (ii) promover ações e iniciativas que visem a diminuir os entraves burocráticos para a regularização fundiária e ambiental e para a promoção de atividades produtivas sustentáveis, particularmente para as pequenas propriedades; (iii) aprimorar a diferenciação regional das estratégias, levando em consideração as zonas previstas no Macrozoneamento da Amazônia 
Legal, assim como as orientações dos zoneamentos estaduais; (iv) Manter o foco específico nos municípios que mais desmatam deve ser mantido, mas considerar a inserção regional desses municípios para evitar o efeito de vazamento do desmatamento; (v) estabelecer a regularização fundiária como prioridade máxima para os próximos anos do PPCDAm; (vi) como segunda prioridade, a estruturação de cadeias produtivas para um modelo sustentável que substitua as práticas predatórias tradicionais na região (IPEA; CEPAL; GIZ, 2011). Em relação a recomendações mais específicas, a Tabela 2 traz uma síntese das mesmas:

\begin{tabular}{l}
\hline Área de Atuação \\
\hline Estrutura e Planejamento \\
Planos Estaduais de \\
Controle ao Desmatamento \\
Municípios Prioritários
\end{tabular}

\section{Macrozoneamento da Amazônia Legal}

Unidades de Conservação e Terras Indígenas

Ordenamento Fundiário

\section{Monitoramento do Desmatamento}

\section{Reformulação do Eixo Fomento a Atividades Sustentáveis}

Diálogo com o Setor Privado

\section{Recomendações}

- Para a próxima fase do PPCDAm, deve ocorrer uma atualização da árvore de problemas.

- As ações do PPCDAm devem ser planejadas a partir dos problemas identificados na árvore e sua execução deve ser atribuída às instituições responsáveis.

-Deve haver uma maior complementaridade e sequenciamento lógico das ações entre os eixos e dentro de cada um deles.

- O PPCDAm deve contar com um conjunto de metas com indicadores de impacto verificáveis através do sistema de monitoramento para os três eixos.

- Planejamento Conjunto e Metas Coerentes.

- Apoio a Pactos Locais.

- Reformular Políticas para Saída da Lista de Municípios Prioritários.

- Criação de Incentivos para Saída da Lista.

- Formular Políticas "Pós-Saída da Lista".

- O PPCDAm deve apoiar o ordenamento territorial local nos municípios prioritários.

- É necessário realizar ZEEs setoriais específicos para as mais importantes cadeias da região - principalmente para a pecuária, grãos e madeira.

- Redefinir a estratégia de criação de UCs e TIs.

- Focalizar a criação de UCs em hotspots.

- Valorização econômica das áreas protegidas.

- Reformulação da estrutura institucional.

- Sistema cartorial integrado e acessível.

- Integração Programa Terra Legal, CAR e licenciamento.

- Destinação de terras públicas e ZEEs.

- Regularização ocupacional de assentamentos.

- Aperfeiçoamento dos sistemas.

- Previsão de futuros desmatamentos.

- Integração entre instituições e entes federativos.

- Rastreabilidade de cadeias produtivas.

- O eixo precisa ser reformulado, superando sua estrutura atual, ainda caracterizada pela sobreposição de ações e atividades que não são articuladas em torno de um objetivo único. Ele deve ter um foco maior nas ações que têm impacto mais direto na prevenção e no controle do desmatamento, que devem ser estruturadas a partir de uma matriz lógica vinculada a uma rede de impactos.

- É necessário consolidar e fomentar o diálogo com o setor privado e o maior envolvimento desse e das organizações da sociedade civil nas atividades que 
promovam a redução do desmatamento, seguindo o exemplo da Moratória da Soja.

Manejo Florestal Sustentável - Aperfeiçoar o marco legal sobre o uso dos recursos genéticos e dos conhecimentos tradicionais a ele associados, para permitir atividades de bioprospecção, pesquisa e exploração de novos produtos.

Tabela 2: Síntese de Recomendações para Revisão do PPCDAm Fase II. Fonte: IPEA; CEEPAL; GIZ, 2011.

Com base nas recomendações da avaliação, iniciou-se o processo de revisão do PPCDAm, que contou om apoio metodológico da Secretaria de Planejamento e Investimentos Estratégicos (SPI), do Ministério do Planejamento, Orçamento e Gestão, e foi formulada a terceira fase do mesmo (PPCDAm, 2012).

\subsubsection{PPCDAM FASE III (2012-2015)}

Na primeira e na segunda fases do PPCDAm (de 2004 a 2011), as ações de maior impacto na queda do desmatamento partiram do eixo Monitoramento e Controle, estando bastante associadas ao desenvolvimento do sistema DETER e ao planejamento integrado da fiscalização. Atualmente, no entanto, observam-se alterações nos padrões de desmatamento, fazendo com que a maior parte dos desmatamentos se encontre abaixo do limiar de detecção do sistema DETER. A redução na área dos polígonos e a sua dispersão (pulverização) aumentam, consequentemente, o custo da fiscalização, que é limitado tanto por recursos humanos quanto orçamentários. Portanto, a redução dos índices anuais de desmatamento até o ano de 2020 em pelo menos 80\% em relação à média verificada entre os anos de 1996 a 2005, na Amazônia Legal, dependerá também do alcance das políticas públicas aos polígonos inferiores a 25 ha, através do fortalecimento dos eixos de Ordenamento Fundiário e Territorial e Fomento às Atividades Produtivas Sustentáveis. Nesse contexto, o PPCDAm iniciou a sua terceira fase de execução (2012- 2015) com um desafio ainda maior: promover ações condizentes com a nova dinâmica do desmatamento e dar escala e eficácia ao eixo de Fomento às Atividades Produtivas Sustentáveis (PPCDAm, 2012).

As diretrizes gerais da nova fase do Plano são: (i) adoção de um estilo de gestão descentralizada e compartilhada de políticas públicas, por meio de parcerias entre a União, Estados e municípios, contemplando a sua integração com incentivos à prevenção de danos ambientais e ao fomento de sistemas sustentáveis de produção; (ii) estímulo à participação ativa dos diferentes setores da sociedade amazônica interessados na gestão das políticas relacionadas à prevenção e controle do desmatamento, como meio para aumentar a qualidade de sua implementação, com transparência, controle social e apropriação política; (iii) apoiar a implementação dos Planos Estaduais de Prevenção e Controle do Desmatamento na 
Amazônia Brasileira; (iv) ampliar e incentivar os pactos setoriais como forma de firmar o comprometimento de entidades dos setores produtivo (soja, madeira, carvão vegetal), visando à preservação e conservação das florestas; e (v) dar visibilidade à realização das ações do Plano.

O novo modelo lógico apontou um conjunto de elementos que foram agrupados por objetivos estratégicos, escolhidos por configurarem as causas primárias, a saber:

Eixo Ordenamento Fundiário e Territorial: (i) promover ordenamento fundiário de terras públicas; (ii) implementar os instrumentos de ordenamento territorial visando à conservação da floresta; (iii) realizar a gestão da malha fundiária de acordo com as diversas categorias fundiárias (PPCDAm, 2012).

Eixo Monitoramento e Controle: (i) tornar mais célere o licenciamento dos Planos de Manejo Florestal e as Concessões Florestais; (ii) aumentar a eficácia da fiscalização e do controle do desmatamento; (iii) aumentar a presença de Estado na Amazônia Legal; (iv) reduzir a impunidade administrativa e criminal relacionadas ao desmatamento ilegal; (v) promover a responsabilização ambiental das principais cadeias produtivas relacionadas ao desmatamento ilegal (PPCDAm, 2012).

Eixo Fomento às Atividades Produtivas Sustentáveis: (i) promover a viabilidade das cadeias produtivas que constituem alternativas ao desmatamento; (ii) fomentar boas práticas agropecuárias, incluindo a substituição do uso do fogo; (iii) aumentar a produção e comercialização de madeira por meio do Manejo Florestal Sustentável; (iv) promover adequação ambiental e fomentar atividades produtivas sustentáveis nos assentamentos da reforma agrária e na Agricultura Familiar; (v) gerar capacitação, tecnologia e informação sobre a Amazônia de modo a subsidiar o desenvolvimento sustentável (PPCDAm, 2012). Para cada eixo de atuação, são definidas, ainda: diretrizes específicas; área prioritária de atuação; impactos esperados e ações que demandam maior integração com os Estados da Amazônia Legal. O eixo de atuação Fomento a Atividades Sustentáveis é aquele que apresenta maior detalhamento na definição de diretrizes e impactos esperados.

Tal estruturação reflete as recomendações do grupo técnico composto por membros IPEA; CEPAL e GIZ em sua avaliação realizada entre 2010 e 2011, conforme mencionado anteriormente. O eixo de Fomento às Atividades Sustentáveis apresentou nova estrutura de planejamento, conforme recomendado pela avaliação. Também é detalhado um novo modelo de governança, que se justifica pela demanda de acompanhamento continuado da execução das ações do Plano, que se divide em três esferas: Executiva, Consultiva e de Transparência. 
Tal configuração facilita a correção de rumos, a tomada de decisão do Ministério do Meio Ambiente como órgão coordenador e a solução de problemas e conflitos que eventualmente possam surgir entre órgãos federais e mesmo entre esses e os estaduais (PPCDAm, 2012). Destaca-se, também, que na terceira fase do PPCDAm é essencial a articulação de ações entre os eixos, com o objetivo de aumentar a eficácia das ações no território.

\subsubsection{Promulgação do Decreto 6321/07: Prevenção, Monitoramento e Controle de Desmatamento no Bioma Amazônia}

No dia 21 de dezembro de 2007, foi assinado o Decreto Federal 6321/07. O referido decreto, com as alterações promovidas pelo Decreto Federal 6514 de 2008, teve por finalidade reforçar e sofisticar a estratégia de enfrentamento dos desmatamentos ilegais na Amazônia Legal. Para tanto, estabeleceu novos mecanismos de controle visando principalmente enfrentar a retomada do desflorestamento na região, verificada no início do segundo semestre de 2007. A partir do Decreto 6321/07, as responsabilidades, dos pontos de vista jurídico, administrativo e político, se ampliaram para além dos agentes diretos do desmatamento ilegal, atingindo os governos estaduais e municipais, a cadeia produtiva e, de forma inédita, os setores econômicos associados ao desmatamento (Lima et al., 2009).

Os principais dispositivos do Decreto 6321/07 são:

a) Identificação de municípios prioritários para a intensificação das ações de prevenção e controle do desmatamento.

$\mathrm{O}$ artigo $2^{\circ}$ do Decreto introduziu um dispositivo que permite que o poder público federal possa priorizar ações de controle e de racionalização do uso do solo em zonas críticas, identificando áreas com risco iminente de degradação. Em tais áreas, consideradas prioritárias, o governo passou a estabelecer e implementar ações mais rigorosas a partir de fevereiro de 2008. Os critérios previstos no Decreto 6321/07 para a seleção dos municípios prioritários para ações de fiscalização e controle são: total desmatado desde o início do monitoramento pelo INPE; total desmatado nos últimos três anos; e aumento da taxa de desmatamento em pelo menos três vezes nos últimos cinco anos, consecutivas ou não. Com base nesta previsão legal inédita, o MMA estabeleceu por meio da Portaria MMA 28, de 27 de janeiro de 2008, uma lista com os 36 municípios prioritários para ações preventivas e de controle dos desmatamentos, responsáveis por 50\% dos desmatamentos de 2007 (Lima et al., 2009).

b) Integração entre regularização fundiária e ambiental

Em seus artigos $3^{\circ}$ ao $7^{\circ}$, o Decreto prevê a possibilidade do Instituto Nacional de 
Colonização e Reforma Agrária - Incra - determinar a obrigatoriedade do recadastramento das propriedades rurais localizadas nos municípios críticos. Com base nesta previsão legal, o Incra editou em 19 de fevereiro de 2008 a Instrução Normativa 44/08 com a convocação para atualização cadastral dos imóveis rurais situados nos municípios constantes da lista de que trata a Portaria MMA 28/08. Esse procedimento visou atualizar e reunir dados e informações geo-espacializadas para monitorar, de forma preventiva, a ocorrência de novos desmatamentos, bem como, promover a integração e a gestão compartilhada entre as políticas agrária, agrícola e ambiental (Lima et al., 2009).

O recadastramento é feito mediante a apresentação pelo proprietário (ou posseiro) de informação georreferenciada do imóvel e de dados sobre uso do imóvel de forma a permitir um monitoramento mais preciso acerca da dinâmica de ocupação do uso do solo. $\mathrm{O}$ recadastramento também tem por objetivo levantar dados para as ações do Incra de regularização fundiária, um dos maiores desafios no que se refere ao controle da expansão das fronteiras agropecuária e florestal ilegais na Amazônia (Lima et al., 2009).

Os imóveis rurais que não apresentaram os dados necessários ao recadastramento no prazo definido pela IN tiveram os seus certificados de cadastro de imóveis rurais (CCIR) tornados sem efeito, o que significa que não estão tendo acesso a crédito público, e poderão sofrer restrições nas transações que envolvam o imóvel (venda, arrendamento, desmembramento, transmissão em herança e oferecimento em garantia a financiamentos público ou privado) (Lima et al., 2009).

\section{c) Definição de novas regras para o crédito rural}

O artigo 11 do Decreto 6321/07 abriu a possibilidade para se efetivar procedimentos de controle sobre a destinação do crédito rural. Com base neste dispositivo, o Conselho Monetário Nacional (CMN) aprovou, em 28 de fevereiro de 2008, a Resolução 3545/08 do Banco Central que estabelece um conjunto de condições ambientais para o acesso ao crédito pelos produtores rurais em imóveis situados nos municípios do Bioma Amazônia (Lima et al., 2009).

\section{d) Embargo do uso econômico de áreas degradadas}

O artigo 12 do Decreto 6321/07 torna compulsório ao agente fiscalizador o embargo de áreas desmatadas ilegalmente. Além do embargo, as áreas degradadas passam a ser obrigatoriamente georeferenciadas a fim de tornar mais efetivo o monitoramento por satélite, sobrevoos e fiscalização de campo.

O Decreto prevê, ainda, a vedação da comercialização do produto obtido na área embargada, a proibição de sua utilização econômica e pesadas sanções ao proprietário que 
desrespeite o embargo. Entre estas penalizações, destacam-se a proibição de obtenção de crédito agropecuário em instituição oficial e o cancelamento de seus registros em órgãos ambiental, fiscais (Receita Federal) e sanitários. Com base neste dispositivo do Decreto 6321/07, o Ministério do Meio Ambiente editou em 29 de fevereiro de 2008, Instrução Normativa 001/08 que regulamenta os procedimentos para o embargo de áreas ilegalmente degradadas e a edição e manutenção de listas e mapas por município dos imóveis e áreas rurais embargados (Lima et al., 2009).

\section{e) Responsabilização da cadeia de produção que adquire produtos oriundos de desmatamento ilegal embargado}

A fim de garantir que as áreas embargadas efetivamente ficarão isoladas da produção, e instituir de forma inédita um modelo de autocontrole da cadeia produtiva na Amazônia, o Decreto 6321/07 prevê, através de seu artigo 13, que as sanções administrativas aplicáveis aos que descumprirem embargo de uso de área ilegalmente desmatada serão aplicadas a quem adquirir, intermediar, transportar ou comercializar produto ou subproduto de origem animal ou vegetal produzido sobre área objeto do embargo lavrado (Lima et al., 2009).

\subsubsection{A Definição de Novas Regras para Obtenção de Crédito Rural: Resolução $3545 / 08$}

Conforme citado acima, o Conselho Monetário Nacional (CMN) aprovou, em 28 de fevereiro de 2008, a Resolução 3545/08 do Banco Central, com o objetivo de definir novas regras para obtenção de crédito rural. As condições exigidas para a obtenção de crédito são as seguintes: a) Certificado de Cadastro do Imóvel Rural (CCIR válido); b) regularidade em relação à Reserva Legal e Área de Preservação Permanente, ou ter dado entrada em procedimento formal para regularização junto ao órgão ambiental estadual; c) imóvel do tomador não pode constar na lista do Ibama de imóveis embargados; e d) seguir as condicionantes do Zoneamento Ecológico-econômico, se houver. Nos casos dos imóveis situados nos 36 municípios da Portaria MMA 28/08, somente poderão ter acesso ao crédito os imóveis que se recadastrarem nos termos da Instrução Normativa (IN) 44/08 do Incra ${ }^{2}$ (BCB, 2008).

2 A Instrução Normativa Incra 44/08 determina o recadastramento junto ao Incra de todas as propriedades rurais situadas nos municípios prioritários. 


\subsubsection{A Implantação do Processo de Cadastro Ambiental Rural}

O Cadastro Ambiental Rural (CAR), instituído pela Lei no 12.651, de 25 de maio de 2012 (o chamado "Novo" Código Florestal) e regulamentado por meio do Decreto $\mathrm{n}^{\mathrm{o}}$ 7.830, de 17 de outubro de 2012. É um instrumento de regularização ambiental de propriedades rurais que objetiva prover informações sobre a conformidade do imóvel rural com as regras de uso do solo previstas na Lei 12.651/12 (Brasil, 2012). Objetiva também responsabilizar proprietários quando da ocorrência de ilícitos ambientais (Brasil, 2012). Trata-se de um registro público eletrônico de âmbito nacional, obrigatório a todos os imóveis rurais, que tem a finalidade de integrar "as informações ambientais das propriedades e posses rurais, compondo base de dados para controle, monitoramento, planejamento ambiental e econômico e combate ao desmatamento" (Brasil, 2012). Tal base de dados é alimentada a partir do levantamento das informações georeferenciadas dos imóveis rurais. O Art. $5^{\circ}$ do Decreto $\mathrm{n}^{\circ}$ 7.830, de 17 de outubro de 2012 define que

O CAR deverá contemplar os dados do proprietário, possuidor rural ou responsável direto pelo imóvel rural, a respectiva planta georeferenciada do perímetro do imóvel, das áreas de interesse social e das áreas de utilidade pública, com a informação da localização dos remanescentes de vegetação nativa, das Áreas de Preservação Permanente, das Áreas de Uso Restrito, das áreas consolidadas e da localização das Reservas Legais (Brasil, 2012).

O sistema eletrônico de âmbito nacional destinado ao gerenciamento de tais informações é o Sistema de Cadastro Ambiental Rural (SICAR), criado pelo Decreto 7.830/12. Todos os imóveis rurais devem estar cadastrados no sistema até 6 de maio de 2015 (http://www.brasil.gov.br). Até 25 de setembro de 2014, 458 mil propriedades rurais ou posses fizeram o seu cadastro ambiental, sendo destas 166.137 propriedades na região Norte; 15.801 na região Nordeste; 82.408 na região Sudeste; 111.381 na região Sul e 82.517 na região Centro-Oeste (http://www.ipam.org.br/).

Embora o Novo Código Florestal tenha instituído o CAR, suas origens podem ser identificadas em experiências anteriores, em Mato Grosso e no Pará. A implementação, em 2000, do Sistema de Licenciamento Ambiental de Propriedades Rurais (SLAPR), no Estado de Mato Grosso, exerceu um papel de destaque no controle do desmatamento ilegal no Estado durante um período determinado (Azevedo et al., 2014). O SLAPR fazia uso do sensoriamento remoto e de ferramentas de sistemas de informação geográfica para tal 
finalidade, e serviu como base para a criação do CAR estadual em Mato Grosso, em 2009, e no Pará. Neste último, as primeiras discussões sobre o CAR tiveram início no auge do processo de descentralização da gestão florestal, em 2006. Sua oficialização como instrumento administrativo foi obtida pelo Decreto n 1.148 de julho 2008 (Azevedo et al., 2014).

Em ambos os Estados, a criação do CAR ocorreu em resposta à crescente pressão pela redução do desmatamento na Amazônia Legal. Além disso, a portaria no 103/2009 do Ministério do Meio Ambiente estabeleceu que o CAR deveria ser realizado em $80 \%$ dos Municípios Prioritários, excluídas as terras indígenas, como condição que estes pudessem deixar a "lista negra" de desmatadores (Azevedo et al., 2014). Ainda, a assinatura de termos de ajuste de conduta (TAC) impostos pelo Ministério Público aos frigoríficos do Pará em 2009 e de Mato Grosso em 2010, tornou obrigatória a apresentação da licença ambiental pelo produtor, que não pode ser obtida sem o CAR (Azevedo et al., 2014).

Com a vinculação ao CAR, os produtores: (i) obtêm licenças para utilização dos recursos naturais ou uso alternativo do solo; (ii) têm as multas aplicadas pelos órgãos fiscalizatórios suspendidas por meio da adesão ao Plano de Recuperação Ambiental (PRA); (iii) obtêm a concessão de crédito agrícola, a partir de 2017; e (iv) a eles são emitidas Cotas de Reserva Ambiental (CRA) quando couber. Além disso, em alguns Estados, ao CAR já estão atreladas algumas exigências de mercado e a oferta de benefícios fiscais (Azevedo et al., 2014). Produtores de médio e grande porte buscam o CAR para a obtenção de empréstimos bancários com juros baixos e para a comercialização de seus produtos com as empresas signatárias de Termos de Ajuste de Conduta (TAC), expedidos pelo Ministério Público. Com a implementação do CAR, almeja-se impactos positivos na redução do desmatamento ilegal em todos os estados da Amazônia Legal.

\subsubsection{Implementação das Moratórias da Soja e da Carne}

Em 24 de julho de 2006, a Associação Brasileira das Indústrias de Óleos Vegetais (ABIOVE) e a Associação Nacional dos Exportadores de Cereais (ANEC) comunicaram que não comercializariam a soja oriunda de áreas de desmatamento no Bioma Amazônia a partir de outubro de 2006. A vigência desse compromisso, mais conhecido como Moratória da Soja, era de dois anos mas, em julho de 2008, em função dos resultados obtidos, foi firmado um Termo de Compromisso estendendo o prazo por mais um ano. Por meio do documento, a ABIOVE e a ANEC comprometem-se a trabalhar em conjunto com órgãos governamentais, 
entidades que representam os produtores rurais e sociedade civil para realizar o monitoramento no Bioma, sensibilizar os sojicultores em relação ao disposto no Código Florestal e colaborar para a aplicação das políticas públicas.

Também foram signatários do Termo de Compromisso as organizações da sociedade civil e o Ministério do Meio Ambiente, que se dispõem a apoiar a Moratória da Soja de diversas formas. As organizações da sociedade civil comprometem-se a cooperar por meio de assessoria técnica e da defesa da criação de mecanismos de remuneração por prestação de serviços ambientais.

No caso da comercialização de carne bovina, foi assinada, em 2009, pelos grandes frigoríficos do país, a Moratória da Carne, que definiu a proibição de compra de carne de boi oriunda de áreas onde o desmatamento ilegal havia sido identificado.

\subsubsection{Formulação de Pactos Setoriais}

Diferentes setores - Governo Federal, Governos Estaduais, empresas, bancos públicos e privados, organizações da sociedade civil e outros - firmaram pactos para a adoção de medidas voltadas a inibir o avanço das atividades predatórias e a incentivar a responsabilidade socioambiental na região. Tratam-se de pactos voluntários e complementares aos esforços governamentais (PPCDAm, 2009).

\subsubsection{Formulação do Pacto pela Valorização da Floresta e pelo Fim do Desmatamento na Amazônia Brasileira}

O Pacto pela Valorização da Floresta e pelo Fim do Desmatamento na Amazônia Brasileira, inclui a participação de importantes organizações não governamentais como: o Instituto Socioambiental (ISA), o Instituto Centro de Vida (ICV), o Instituto de Pesquisa Ambiental da Amazônia (IPAM), o Instituto do Homem e Meio Ambiente da Amazônia (IMAZON), o WWF Brasil, a Conservação Internacional (CI) e a The Nature Conservancy (TNC). Um dos principais mecanismos financeiros propostos pelo Pacto é a Redução Compensada do Desmatamento. O Pacto propõe a criação de um fundo amazônico para pagamento por serviços ambientais (PPCDAm, 2009).

\subsubsection{Estabelecimento de Protocolos de Intenções pela Responsabilidade Socioambiental entre MMA, BNDES, CEF, BASA, BB e BNE e entre MMA e FEBRABAN (chamado de Novo Protocolo Verde)}

Reconhecendo os avanços obtidos no caminho do financiamento sustentável por parte 
dos bancos signatários do antigo Protocolo Verde (acordado em 1995) e, em decorrência da necessidade de ajustes ao referido documento, foi firmado, em 01 de agosto de 2008, o Protocolo de Intenções pela Responsabilidade Socioambiental. São signatários desse documento o MMA, o Banco Nacional de Desenvolvimento Econômico e Social (BNDES), a Caixa Econômica Federal (CEF), o Banco do Brasil (BB), o Banco da Amazônia (BASA) e o Banco do Nordeste do Brasil (BNB) (PPCDAm, 2009).

Posteriormente, em abril de 2009, o MMA e a Federação Brasileira de Bancos (FEBRABAN) assinaram Protocolo similar ao firmado com os bancos públicos. O objetivo da celebração de ambos os protocolos é estabelecer a convergência de esforços para o empreendimento de políticas e práticas bancárias que sejam precursoras, multiplicadoras, demonstrativas ou exemplares em termos de responsabilidade socioambiental e que contribuam para o desenvolvimento sustentável (PPCDAm, 2009).

\subsubsection{Firmamento de Protocolo de Intenções entre MMA e FIESP}

Em 13 de agosto de 2008, o MMA e a Federação das Indústrias do Estado de São Paulo (FIESP) firmaram um protocolo de intenções, com o objetivo de estabelecer diretrizes básicas para o desenvolvimento de ações voltadas à promoção da produção, o uso e o consumo sustentável dos produtos madeireiros da floresta amazônica (PPCDAm, 2009).

\subsubsection{Combate à Ilegalidade no Setor Madeireiro}

Além dos esforços de combate ao desmatamento acima apresentados, devem ser destacados os esforços nacionais e internacionais que vêm se concentrando na criação de melhores mecanismos que resultem na exploração madeireira racional e legal. Entre estes, citam-se:

\section{a) O Desenvolvimento e Implantação de Planos de Manejo Sustentável}

O manejo sustentável de florestas e seus princípios foram definidos oficialmente no Decreto 1282/94 (Waldhoff \& Vidal, 2014). O marco regulatório foi aprimorado ao longo de anos por um conjunto de normas que incluem a elaboração de Planos de Manejo Florestal Sustentável, Planos Operacionais Anuais e o monitoramento do manejo florestal por meio de vistorias técnicas (MMA, 2013). Em 1990, esforços internacionais para a conservação de florestas tropicais resultaram na criação do Programa Piloto para a Proteção das Florestas Tropicais do Brasil (Waldhoff \& Vidal, 2014 apud Antoni, 2010; Fearnside, 2003). Dentro deste Programa, o projeto "Apoio ao Manejo Florestal Sustentável na Amazônia" 
(ProManejo) apoiou 46 projetos relacionados ao manejo florestal sustentável, 14 dos quais eram diretamente dedicados às comunidades tradicionais da região (Waldhoff \& Vidal, 2014).

O sistema de manejo florestal utilizado na Amazônia é policíclico. Baseia-se em ciclo de corte de 35 anos, para uma intensidade de corte máxima de $30 \mathrm{~m}^{3} \mathrm{ha}^{-1}$.A seleção de árvores é baseada em critérios técnicos e ecológicos de forma a promover a regeneração das espécies florestais manejadas (MMA, 2013).

\section{b) O Desenvolvimento do Programa de Concessões Florestais}

Em resposta à significativa importância da indústria madeireira amazônica, o governo brasileiro desenvolveu o Programa de Florestas Nacionais. As Florestas Nacionais (Flonas) são Unidades de Conservação federais na categoria de uso sustentável, que se caracterizam por possuir áreas com cobertura florestal de espécies predominantemente nativas e têm como objetivo básico o uso múltiplo sustentável dos recursos florestais e a pesquisa científica, com ênfase em métodos para exploração sustentável de florestas nativas (SBF, 2011 apud SNUC, 2000). A Lei de Gestão de Florestas Públicas - Lei 11.284/2006, que instituiu o Serviço Florestal Brasileiro - criou a possibilidade de concessão a empresas e comunidades áreas de florestas públicas para manejo com fins de extração de madeira e produtos não madeireiros, além da oferta de serviços turísticos. Em contrapartida ao direito do uso sustentável, os concessionários pagam ao governo quantias que variam em função da proposta de preço apresentada durante o processo de licitação destas áreas. A política de concessão florestal tem como objetivo o gerenciamento dos recursos florestais por parte dos governos federal, estaduais e municipais de forma a promover uma economia em bases sustentáveis e de longo prazo, evitando: (i) a grilagem de terras; (ii) a exploração predatória dos recursos naturais; e (iii) a conversão do solo para outros fins, como agricultura e pecuária. Além da Lei 11.284/2006, a Lei Geral de Licitações (8666/93) também rege os processos de concessões florestais. A primeira descreve como ocorre esse processo, que envolve o levantamento das áreas em todo o país passíveis de concessão, a elaboração do edital, a licitação e o monitoramento da atividade. A segunda estabelece regras gerais para as licitações, visando garantir a publicidade, isonomia, impessoalidade, objetividade, entre outros princípios (www.florestal.gov.br). Até maio de 2015, existiam 32 Flonas na Amazônia Legal, cobrindo uma área de aproximadamente 14,3 milhões de hectares. Durante a última década, foram realizadas, na região, concessões de uso em 4 destas Flonas, o que correspondeu a 460 mil hectares. Espera-se que até o final de 2015 sejam realizadas mais 18 concessões, o que levaria a uma área total de 1.345.00 hectares de Flonas sob concessão (Ramos, Silva \& Merry, 2015). 


\section{c) O Desenvolvimento Programa de Manejo Florestal Comunitário e Familiar}

O Programa de Manejo Florestal Comunitário e Familiar (PMFC) objetiva coordenar as ações de gestão e fomento ao manejo florestal sustentável voltadas para os povos, comunidades tradicionais e agricultores familiares que tiram sua subsistência das florestas brasileiras. O Programa foi instituído no âmbito do MMA e Ministério do Desenvolvimento Agrário (MDA), em 5 de junho de 2010, pelo Decreto $n^{\circ}$ 6.874, de 05 de junho de 2009. Tal Decreto lista os princípios e diretrizes do PMCF: (i) desenvolvimento sustentável, por meio do uso múltiplo dos recursos naturais, bens e serviços das florestas; (ii) geração de trabalho e renda para os beneficiários; (iii) identificação e valorização das diversas formas de organização social, cultural e produtiva das comunidades, visando o respeito às especificidades dos beneficiários e dos diferentes biomas; (iv) promoção do acesso das comunidades aos institutos jurídicos que permitam a regularização da posse e do uso das áreas ocupadas nas florestas da União, quando este uso for permitido pela legislação em vigor; (v) fomento à elaboração e implementação de planos de manejo como instrumentos aptos a orientar os manejadores na gestão adequada da produção sustentável; (vi) promoção de assistência técnica e extensão rural adaptadas ao manejo florestal comunitário e familiar; (vii) promoção da educação ambiental como instrumento de capacitação e orientação da juventude rural, visando estimular a sua permanência na produção familiar, de modo a assegurar o processo de sucessão; (viii) estimular a diversificação produtiva e a agregação de valor à produção florestal de base comunitária e familiar; e (ix) fomento à pesquisa, ao desenvolvimento e à apropriação de tecnologias pelos beneficiários (www.florestal.gov.br).

\section{d) A Criação do Distrito Florestal Sustentável da BR-163}

O Decreto Presidencial de 13 de fevereiro de 2006 instituiu o complexo geoeconômico e social denominado Distrito Florestal Sustentável (DFS) da BR-163, com a finalidade de implementação de políticas públicas de estímulo à produção florestal sustentável. Também foi criado, nesse dispositivo legal, um Grupo de Trabalho Interinstitucional (GTI), com representantes da Casa Civil da Presidência da República e dos ministérios do Meio Ambiente; da Agricultura, Pecuária e Abastecimento; da Ciência e Tecnologia; do Desenvolvimento Agrário; do Desenvolvimento, Indústria e Comércio Exterior; da Educação; da Fazenda; da Integração Nacional; de Minas e Energia; do Planejamento, Orçamento e Gestão; do Trabalho e Emprego; e dos Transportes. Sua finalidade foi a de propor ações 
voltadas ao fomento do desenvolvimento sustentável, com base em atividades florestais sustentáveis, do DFS da BR-163 (MMA, 2013). O DFS da BR-163 abrange pouco mais de 19 milhões de hectares e está localizado na região oeste do estado do Pará. Compreende a área que se estende de Santarém até Castelo dos Sonhos, no eixo da BR-163 (Cuiabá - Santarém), e de Jacareacanga a Trairão, no eixo da BR-230 (Transamazônica). Aproximadamente 57\% da área do DFS da BR-163 é formada por unidades de conservação federais, o que totaliza 10,8 milhões de hectares, dos quais 8,3 milhões pertencem à categoria de Unidades de Conservação Federais de Uso Sustentável (MMA \& SBF, 2013).

Além disso, o reconhecimento da importância da contribuição do desmatamento e degradação florestal para as emissões antropogênicas de GEE levou a propostas de inclusão de Reduções de Emissões por Desmatamento e Degradação (REDD) no acordo climático pós2012 na Convenção-Quadro das Nações Unidas sobre Mudanças do Clima - UNFCCC. Em 2010, os Acordos de Cancun expandiram o escopo das atividades de mitigação das mudanças climáticas para incluir a conservação de estoques de carbono e aprimoramento das práticas de manejo florestal sustentável (Morton et al., 2011). Assim, países detentores de florestas tropicais que comprovassem as reduções de emissões nacionais oriundas de desmatamento receberiam compensação financeira internacional correspondente às emissões evitadas (IPAM, 2012). Posteriormente a criação deste conceito, a Convenção incluiu na sua definição também atividades de conservação, manejo sustentável das florestas e aumento de seus estoques em países em desenvolvimento. Estes componentes deram origem ao REDD+.

Citam-se, ainda, como medidas de combate ao desmatamento na Amazônia Legal: (i) a criação do Fundo Amazônia, que tem por finalidade captar doações para investimentos nãoreembolsáveis em ações de prevenção, monitoramento e combate ao desmatamento, e de promoção da conservação e do uso sustentável das florestas na região (Marcovitch, 2013); (ii) a elaboração dos Planos Estaduais de Redução de Desmatamento; (iii) a implementação do Sistema de Incentivos aos Serviços Ambientais, no Acre (http://www.ac.gov.br); e (iv) a criação do Programa Municípios Verdes, no Pará (http://municipiosverdes.com.br/).

Verifica-se, então, que diversas medidas que objetivam o controle do processo de desmatamento na Amazônia Legal vêm sendo implementadas. No entanto, é necessário entender quais foram os fatores de maior impacto na redução do desmatamento na região observada entre 2005 e 2013. No capítulo seguinte, tais fatores serão apresentados e analisados com base nos resultados das realizações de entrevistas, levantamento bibliográfico e compilação de dados estatísticos. 


\section{CAPÍTULO 3 - ANÁLISE DOS FATORES QUE LEVARAM À REDUÇÃO DE DESMATAMENTO ENTRE 2005 E 2013 NA AMAZÔNIA LEGAL}

Afirma-se que redução da taxa de desmatamento, entre 2005 e 2013, na Amazônia Legal, deveu-se a uma sinergia de elementos econômicos, políticos, sociais e tecnológicos. No entanto, obter uma resposta quantitativa que elucide como cada fator influenciou, em maior ou menor proporção, tal redução é um processo de alto nível de complexidade (Moutinho, 2014). Rajão (2014) afirma que a dificuldade científica relacionada ao entendimento das dinâmicas de uso do solo na região durante o período acima citado reside no fato de que, historicamente, quando o desmatamento era associado a, apenas, decisões de investimento (principalmente relacionadas à expansão de lavouras e expansão de atividades pecuárias), podia-se compreender as dinâmicas de mudanças de uso do solo a partir do emprego de modelos econométricos. No entanto, a partir do momento em que houve o despertar da necessidade - e consequente tomada de ação - de combate ao desmatamento, passou a existir a influência da presença do Estado e de mudanças socioculturais. A partir desse ponto, modelos econométricos deixaram de ser suficientes para explicar a dinâmica de desmatamento na região, pois o grau de complexidade associado à modelagem de elementos culturais é extremamente elevado (Rajão, 2014).

Com a finalidade de aprofundamento em relação ao entendimento de tais questões, foram realizadas entrevistas com os principais atores envolvidos no debate em torno das dinâmicas de uso do solo na Amazônia Brasileira. A Tabela 3 traz uma síntese dos fatores predominantes responsáveis pela redução do desmatamento na região entre 2005 e 2013, segundo tais atores. 


\begin{tabular}{lrcr}
\hline Fearnside (2014) & Moutinho (2014) & \multicolumn{2}{c}{ Soares-Filho } \\
& & Fase I (2005-2007): (i) Criação de \\
\hline Fase I (2005-2007): (i) & Fase I (2005-2007): \\
diminuição dos preços & quase 25 milhões de hectares de áreas protegidas & (i) & Crise da economia \\
das commodities de & na Amazônia; (ii) Ações de fiscalização; (iii) & agrícola; (ii) expansão de \\
carne e soja; (ii) & Queda do preço das commodities no mercado áreas protegidas; (iii) aumento \\
variação das taxas internacional. & da fiscalização; (iv) aporte \\
cambiais. & & financeiro internacional.
\end{tabular}

Fase II (2008 - 2013): (i) Criação da

Fase II (2008- "lista negra" de Municípios Prioritários; (ii)

Fase II (2008-2013): 2013): Resolução 3545 Restrição de Crédito Rural; (iii) Ação de Criação da "lista negra" de do Banco Central. $\quad$ combate ao desmatamento em nível estadual.

Municípios Prioritários e

Restrição ao Crédito Rural.

\begin{tabular}{|c|c|c|}
\hline Valeriano (2014) & Setzer (2014) & Azevedo (2014) \\
\hline \begin{tabular}{lr} 
Fortalecimento & do \\
monitoramento e das \\
medidas de fiscalização \\
a partir de \\
implementação, em \\
2004, do PPCDAm. \\
\multicolumn{3}{c}{ Destaque: } \\
Valorização \\
agentes responsáveis \\
pela fiscalização em \\
campo.
\end{tabular} & $\begin{array}{l}\text { Aprimoramento das } \\
\text { medidas de fiscalização. }\end{array}$ & 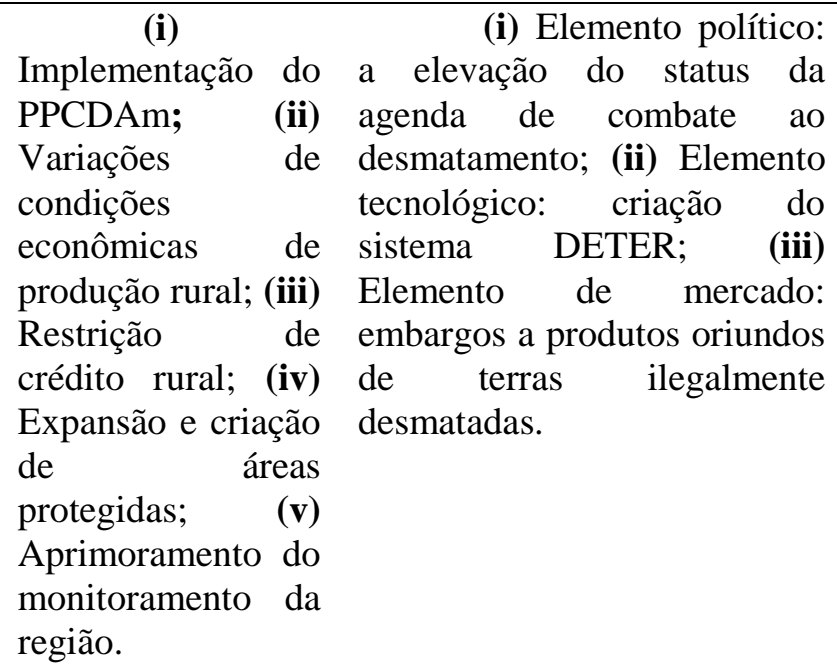 \\
\hline
\end{tabular}

Tabela 3: Síntese dos fatores predominantes responsáveis pela redução das taxas de desmatamento na Amazônia Legal entre 2005 e 2013, segundo principais atores envolvidos no debate acerca do tema. Fonte: Entrevistas realizadas em 2014 (Anexos I, II, III, IV, V, VI e VII).

Fearnside (2014) afirma que há a distinção entre duas fases: na primeira fase, entre 2005 e 2007, segundo diversos estudos econométricos realizados, a redução do desmatamento está associada à diminuição dos preços das commodities de soja e carne de boi e, também, às variações das taxas cambiais (valorização da moeda Real) durante o período citado. Na fase seguinte, de 2008 em diante, os preços das commodities se recuperam e o fator mais evidente para a manutenção do declínio das taxas de desmatamento foi a Resolução 3545 do Banco Central, que restringe o crédito agrícola às atividades produtivas associadas ao desmatamento ilegal. Para Fearnside (2014), a restrição de crédito constitui-se no fator que explica a 
manutenção da redução de desmatamento mesmo quando os preços das commodities se eleva, sendo a eficácia dessa medida evidente, já que o acesso ao crédito é imediatamente suspenso quando detectadas irregularidades; tal ação vem a ser muito mais rigorosa do que a aplicação de multas, já que não se pode recorrer a recursos para a suspensão da penalidade.

Moutinho (2014) também argumenta que a redução do desmatamento está relacionada a fatores diferentes, distribuídos em períodos diferentes; cita que, no período de 2005 a 2007, três fatores fundamentais devem ser destacados: (i) a criação de quase 25 milhões de hectares de áreas protegidas na região; (ii) a forte ação de fiscalização e de campanhas do Governo Federal através do IBAMA e da Polícia Federal, que tiveram efeitos bastante efetivos na derrubada da taxa e (iii) a queda do preço das commodities no mercado internacional. No período após 2008, cita como principais fatores aos quais está associada a redução do desmatamento a criação da "lista negra" de Municípios Prioritários e a Restrição de Crédito Rural estabelecida pela Resolução 3545. Moutinho (2014) destaca, também, nesse segundo período, o papel da ação em nível estadual, que envolveu a discussão intensificada relacionada às metas de redução de desmatamento e as discussões em torno dos Planos Estaduais de Redução de Desmatamento. São exemplos: no Mato Grosso, a implementação de Legislação voltada para REDD; no Pará, o Programa Municípios Verdes e ICMS Verde; e no Acre, a implementação do Sistema de Incentivos aos Serviços Ambientais (SISA), com uma série de investimentos oriundos de um convênio com o Governo Alemão, o Fundo Amazônia e o Banco Mundial.

Soares-Filho (2014) afirma, também, que a redução da taxa de desmatamento se deu em diferentes fases e devido a uma sinergia de vários fatores distintos. Durante a primeira fase, o período de 2005 a 2007, os fatores correlacionados com a redução de desmatamento destacados por Soares-Filho (2014) são: (i) a queda de rentabilidade da agricultura em um momento de crise da economia agrícola, ocasionando o arrefecimento dos atores, que estavam descapitalizados na época; (ii) a expansão de áreas protegidas, observando-se uma mudança de paradigma com uma nova política de criação de áreas protegidas em áreas de fronteira agrícola ativa, opondo-se ao padrão de criá-las em locais definidos como hotspots de biodiversidade, que eram, em sua maioria, áreas remotas (tal medida tirou grande área florestal do mercado especulativo de terra, tornando inviável as práticas de grilagem); (iii) o papel do Estado, sob a liderança de Marina Silva e João Capobianco, atuando no aumento da fiscalização e da implementação de medidas de comando-e-controle com o PPCDAm e as Políticas Ambientais Estaduais, ocasionando aumento das campanhas de campo e das forçastarefas de fiscalização e punição, além da perseguição de redes de corrupção relacionadas a 
atividades de desmatamento (sobretudo em relação às atividades de exploração madeireira); e (iv) o aporte financeiro internacional. Na segunda fase, o período posterior a 2008, a criação da lista negra de municípios e restrição ao crédito rural são citados como políticas-chaves. Soares-Filho (2014) destaca, ainda, o importante espaço que a ciência vem ganhando para influenciar a formulação de políticas públicas, com impactos importantes advindos de: (i) estudos do Centro de Sensoriamento Remoto da Universidade Federal de Minas Gerais, e outros laboratórios, que desenvolvem trabalhos com o MMA, o Ministério da Fazenda, o Serviço Florestal Brasileiro, a Secretaria de Assuntos Estratégicos e as Secretarias Estaduais; (ii) Resultados do SISAMAZONIA e sistemas similares, que correram o ambiente político, sendo utilizados por muitos governadores no planejamento de suas ações; (iii) resultados gerados pelo PRODES e DETER; (iv) estudos do IMAZON para planejamento territorial; e (v) estudos do LBA - Experimento de Grande Escala da Biosfera-Atmosfera na Amazônia. O conhecimento científico gera, também, subsídios para o ativismo das ONGs (especialmente as nacionais, como IMAZON, IPAM, entre outras), cujo papel na promoção de debates com as políticas públicas é grande.

Valeriano (2014), entretanto, argumenta que a partir da implementação do PPCDAm em 2004, o fortalecimento do monitoramento e as medidas de fiscalização foram as forças propulsoras principais de redução da taxa de desmatamento. Em relação às medidas de fiscalização, ressalta que estas foram alavancadas pela valorização do trabalho dos agentes de campo - especialmente relacionada ao trabalho do então ministro Carlos Minc, que foi a campo com os técnicos que realizam a fiscalização, destacando a importância do papel de tais agentes - além do aprimoramento do planejamento das ações a partir dos dados gerados pelo DETER. Valeriano (2014) destaca, ainda, o papel da Operação Curupira, a qual considera ser o marco que deixou clara a necessidade de redução do desmatamento e momento que leva a produção dos dados gerados pelo INPE à mídia, além de ser elemento a partir do qual o nível de corrupção no IBAMA é reduzido. Para Setzer (2014), o aumento e aprimoramento das medidas de fiscalização também é a resposta para o porquê da redução do corte raso na região, afirmando que na ausência de tais medidas, a redução não teria ocorrido; argumenta, ainda, que os fatores econômicos e climáticos intensificaram ou reduziram esta condição.

Azevedo (2014) afirma que cinco principais elementos explicam a redução da taxa de desmatamento: (i) a implementação do PPCDAm, que gerou a ação orquestrada de combate ao desmatamento; (ii) as variações de condições econômicas de produção rural (não associadas a preços dos produtos, mas a condições relacionadas à infraestrutura e ao clima, que têm grande impacto na produção rural); (iii) a implementação de mecanismos de 
desincentivo econômico ao desmatamento, como a restrição de crédito rural; (iv) a expansão e criação de áreas protegidas; e (v) o aprimoramento do monitoramento da região.

Rajão (2014) cita três elementos que devem ser destacados como fatores que influenciaram na redução da taxa de desmatamento: (i) o elemento político: a elevação do status da agenda de combate ao desmatamento, pela ministra Marina Silva, no início do primeiro governo do presidente Luiz Inácio Lula da Silva; (ii) o elemento tecnológico: a criação do sistema DETER, que possibilitou a ligação entre o debate conceitual e as ações efetivas de combate ao desmatamento; e (iii) o elemento de mercado: a partir de 2008, produtores começaram a encontrar problemas, pois sua mercadoria não estava sendo aceita no mercado externo devido ao fato de seu município constar na Lista Negra de municípios desmatadores, o que ocasionou mudanças comportamentais devido ao efeito dos mercados.

Em estudo que acorda com as visões, acima descritas, de Fearnside, Moutinho e Soares-Filho, Nepstad et al. (2014) distinguem fases diferenciadas no período de redução do desmatamento. Entre 2005 e 2007, fase intitulada "Frontier Governance", o declínio das taxas de desmatamento é descrito como resultado de diversos fatores que se reforçam mutuamente. Tais fatores são: (i) a retração das áreas de plantação de soja; (ii) a intensificação da produção pecuária; (iii) a redução do número de cabeças de gado na região; (iv) aumento do risco das práticas de desmatamento a partir da aplicação da legislação ambiental de forma aprimorada, da aplicação de multas e embargos a produtos associados a desmatamento ilegal e efeitos da Moratória da Soja; (v) a expansão de áreas protegidas e (vi) a estagnação da pavimentação de estradas (Nepstad et al., 2014). Na fase seguinte, denominada "Territorial Perfomance", a lucratividade da produção de soja elevou-se, assim como as atividades produtivas. No entanto, demandas por novas áreas desmatadas relacionadas a tais atividades produtivas não ocorreram, pois 50\% da expansão da produção de soja até 2013 se deu em áreas desmatadas anteriormente ao ano de 2006 (Nepstad et al., 2014). Durante essa fase, os riscos associados ao desmatamento foram elevados através de duas medidas: a implementação do Decreto 6321/07 (conforme descrito no Cap. 2) e a Moratória da Carne (Nepstad et al., 2014).

A seguir, serão detalhados os impactos dos fatores acima citados na redução das taxas de desmatamento.

\subsection{DinÂMiCAS RELACIONADAS A ATIVIDADES AgROPECUÁRIAS}

As atividades pecuárias e de produção de soja são elencadas como importantes vetores de desmatamento na Amazônia Legal, portanto é fundamental entender como a dinâmica relacionada a tais atividades vêm evoluindo. O número de cabeças de gado concentrado em 
cada estado da Amazônia Legal ${ }^{3}$ entre 1988 e 2013 é apresentado na Figura 10. A evolução da área dedicada à plantação de soja em cada estado da Amazônia Legal entre 1990 e 2013 é apresentada na Figura 11. Verifica-se que os estados com maior expressividade em termos de concentração de número de cabeças de gado e área total de plantação de soja são Mato Grosso, Pará e Rondônia, sendo este primeiro especialmente expressivo em termos de área dedicada a plantação de soja.

\section{Efetivo dos Rebanhos Bovinos}

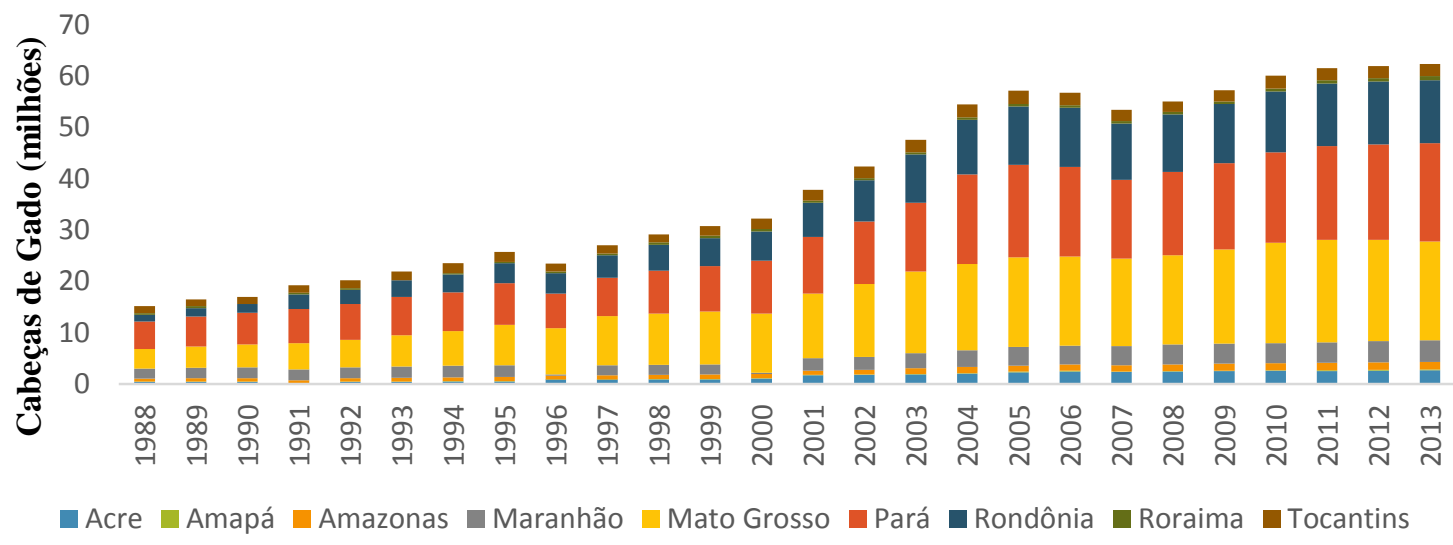

Figura 10: Evolução do efetivo dos rebanhos bovinos nos estados da Amazônia Legal entre 1988 e 2013. Fonte: IBGE, 2014.

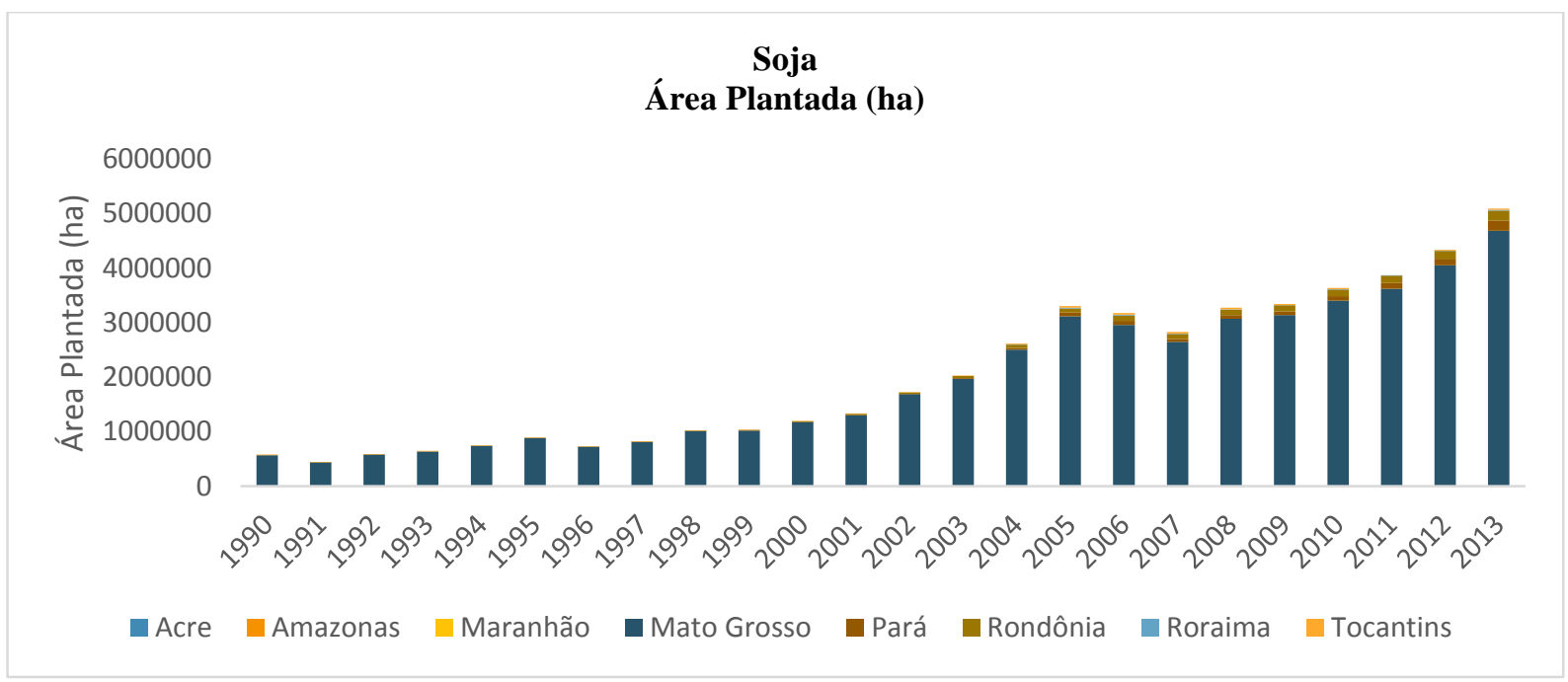

Figura 11: Evolução da área de plantação de soja nos estados da Amazônia Legal, entre 1990 e 2013. Fonte: IBGE, 2014.

${ }^{3}$ Para os estados do Maranhão, Mato Grosso e Tocantins, foram considerados apenas os dados dos municípios dentro do Bioma Amazônia.

${ }^{4}$ Ano de início de registro de áreas dedicadas à plantação de soja na região. 
Em relação ao efetivo dos bovinos, a média de crescimento do número de cabeças de gado no período entre 1988 e 2004 foi de de 8,5\% ao ano, tendo sendo mais expressivos os aumentos anuais observados em 1991 (15,5\%), 1995 (9,6\%), 2000 (10,7\%), 2001 (11\%), 2002 (12\%), $2003(12,2 \%)$ e 2004 (14,3\%). O ano de 2005 apresentou aumento de apenas 4,9\% em relação ao ano anterior; em 2006, houve redução de 0,63\% no número de cabeças de gado em relação a 2005, e em 2007 a redução foi de 5,85\% em relação ao número anterior. A partir de 2008 o número de cabeças de gado voltou a apresentar crescimento. Em tal ano, o crescimento foi de 3,06\% em relação ao ano anterior. Para o período de 2008 a 2013, a média de crescimento foi de 2,6\% ao ano; nos anos de 2012 e 2013, tal índice foi de 0,7\% e 0,67\%, respectivamente. Desta forma, verifica-se que entre 2005 e 2013, o crescimento anual do número de cabeças de gado na Amazônia Legal deixou de ser tão expressivo quando comparado com aquele observado entre 1988 e 2004.

No caso do total de área dedicada a plantação de soja, a média de crescimento para os anos de 1990 a 2004 foi de 12,5\% ao ano, destacando-se os anos de 1992 (crescimento de 33\%), 1995 (crescimento de 19,3\%), 1998 (crescimento de 25,4\%), 2002 (crescimento de 30\%) e 2004 (crescimento de 30\%). Entre 2005 e 2013, tal média foi de 9,7\% ao ano, e destaca-se a redução da área plantada em 2006 (3,6\%) e 2007 (11\%). Em 2008, houve aumento das áreas plantadas na região de $15,5 \%$ em relação ao ano anterior, e em 2013, tal aumento foi de $17,2 \%$ - tais foram os aumentos mais expressivos observados no período após 2004; tanto em 2008 quanto em 2013, ocorreu aumento de desmatamento em relação ao ano anterior. Porém, análises estatíticas robustas se fazem necessárias para confirmar se existe uma relação de causalidade estatisticamente significativa.

É interessante observar que durante o período de redução das taxas de desmatamento (2005 a 2013), o aumento - quando existiu - no número de cabeças de gado na Amazônia Legal foi significantemente inferior ao observado no período entre 1980 e 2004, em termos percentuais. Pode-se inferir que tal fator estaria associado à redução de desmatamento na região. No entanto, análises estatísticas robustas também são necessárias para confirmar se existe uma relação de causalidade estatisticamente significativa. Deve-se ainda destacar que Barreto \& Silva (2013) afirmam que houve aumento de produtividade na produção pecuária na Amazônia Legal devido a i) abertura de novos pastos; e ii) investimento no setor (Barreto \& Silva, 2013). Apesar dos avanços, a produtividade pecuária ainda está abaixo do potencial, cuja média é de cerca de 80 quilogramas de carne por hectare por ano. Alguns trabalhos na literatura citam potencias de produtividade maiores, atingindo até 300 quilogramas por hectare por ano (Barreto \& Silva, 2013). 
A redução de número de cabeças de gado e área de plantação de soja observada especialmente nos anos de 2006 e 2007 está relacionada à redução dos preços das commodities de soja e carne de boi e à valorização da moeda Real nesse período. Fearnside (2014), Moutinho (2014), e Soares-Filho (2014) afirmam que a diminuição de tais preços, em 2005 e 2006, ocasionou a redução de incentivo para a plantação de soja e criação de rebanho bovino, e que tal fato teve influência na redução da taxa de desmatamento no período entre 2005 e 2007. Fearnside (2014) aponta que a valorização da moeda Real em tal período também exerceu papel importante nesse âmbito; Na Figura 12 observa-se a relação entre taxas cambiais e desmatamento entre $1995^{5}$ e 2013. Verifica-se que especialmente nos anos 2002, 2003 e 2004, a valorização do dólar em relação ao real apresenta correlação positiva com o aumento de desmatamento. Apesar de tal correlação não demonstrar causalidade, deve-se ressaltar que a desvalorização do Real incentiva a exportação de produtos agropecuários, conforme citado no Capítulo 1. Fearnside (2014) argumenta, concordando com Nepstad (2006), que a valorização do Real (iniciada em 2004 e mais fortemente sentida a partir de 2005) foi um fator importante para a desaceleração da expansão da agroindústria e da criação de gado na região, o que se refletiu na redução da taxa de desmatamento.

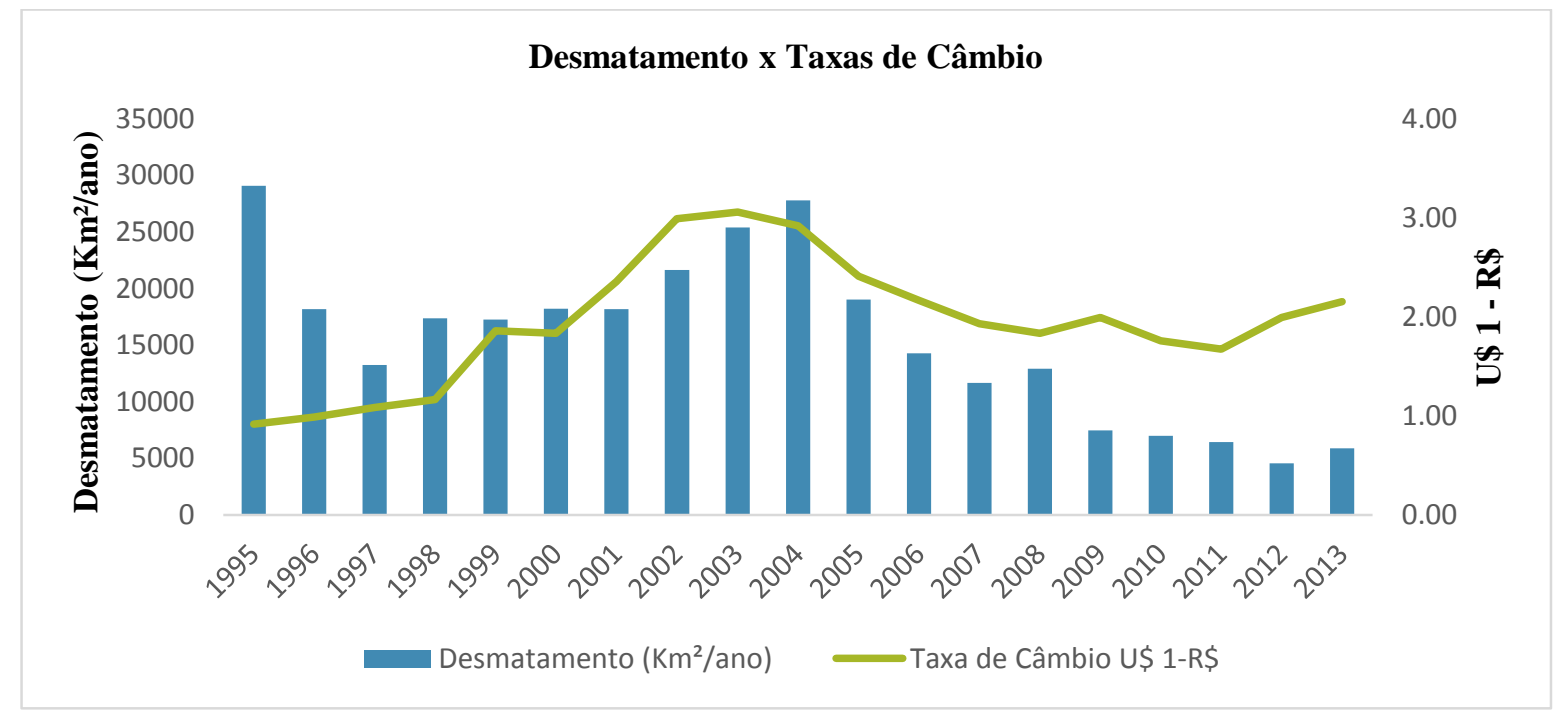

Figura 12: Relação entre desmatamento e taxas de câmbio, entre 2004 e 2013. Fonte: BCB, 2014; INPE, 2014.

A Figura 13, abaixo, ilustra a relação entre desmatamento e os preços das sacas de soja e de arroba do boi, entre $1995^{6}$ e 2013. A redução observada em 2005 e 2006 ocorreu após um período de aumento constante de ambos preços (1998 a 2004). Em 2005, houve redução de

\footnotetext{
${ }^{5}$ Ano a partir do qual a moeda Real passou a estar em circulação em todos os meses.

${ }^{6}$ Ano a partir do qual os dados estão disponíveis.
} 
aproximadamente $26 \%$ no preço da saca de soja e $9 \%$ no preço do arroba do boi em relação a 2004. Em 2006, a redução foi aproximadamente 3\% para o arroba do boi e aproximadamente $10 \%$ para a saca de soja em relação ao ano anterior. Em 2007, no entanto, os preços de tais commodities começaram a apresentar aumentos (aproximadamente 15\% arroba do boi; aproximadamente $22 \%$ saca de soja). Em julho de 2008, ambas as commodities alcançaram altas recordes; em todos os meses, os valores estiveram significativamente acima dos mesmos meses nos três anos anteriores (Lima et al., 2009). A partir de então, tais preços mantiveramse em ascenção, exceto para o caso do preço da saca de soja no ano de 2010.

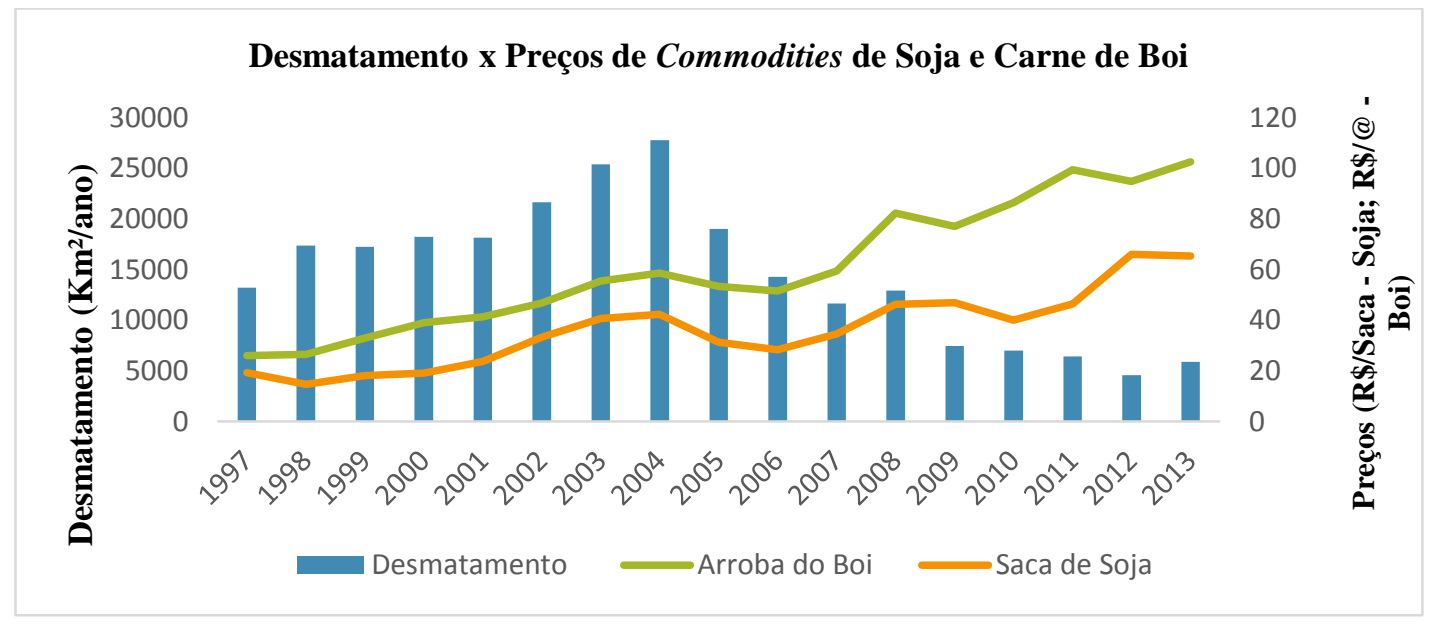

Figura 13: Relação entre desmatamento e preços soja e boi, entre 1997 e 2013. Preços de sacas de soja: média anual do estado do Paraná. Preço arroba do boi: média anual do estado de São Paulo. Fonte: CEPEA, 2014; INPE, 2014.

Os preços das commodities são majoritariamente regulados por variáveis macroeconômicas como relação entre estoque/consumo mundial, inflação, taxas de juros e câmbio, além de variáveis climáticas (Rosolen, Araújo e Lyrio, 2013; Verburg et al., 2014). Dois fatores relacionados à demanda ajudam a explicar o movimento de alta de preços das commodities de carne de boi e soja, fortemente sentido a partir de 2008 . O primeiro é o fato de que economias emergentes, especialmente a China, vêm impulsionando a demanda por essas commodities; tal fato resultou do crescimento da renda per capita, da rápida industrialização e do crescimento populacional. O segundo fator foi a redução das taxas de juros na economia norte-americana (Lima \& Margarido, 2008). Em relação a fatores relacionados à oferta, destacam-se: (i) a depreciação do dólar americano, já que em momentos de perda de seu valor frente a outras moedas, os produtores de commodities que têm capacidade de definir preços internacionais buscam aumentar os preços de seus produtos em dólares como forma de manter o seu poder de compra e assim compensar a depreciação de tal moeda; e (ii) as transmissões de preços entre diferentes commodities, ressaltando-se que 
aumentos de preços de petróleo, como ocorrido em 2008, acabam por elevar a produção de biocombustíveis, o que acarreta o aumento dos preços de de seus insumos (Lima \& Margarido, 2008).

Em 2008, houve aumento anual de desmatamento em aproximadamente 11\%; tal fato está associado ao aumento dos preços das commodities iniciado em 2007. Conforme descrito anteriormente, Fearnside (2014), Moutinho (2014) e Soares-Filho (2014) apontam a restrição de concessão de crédito rural como um fator-chave para a reversão da tendência de aumento de desmatamento verificada em tal ano. Os impactos de tal política serão descritos a seguir.

\subsection{Os Impactos dA ResoluÇÃo 3545: RestriçÃo de CONCESSÃo de CRÉdito RURAL}

A direção do efeito da redução da concessão de crédito nas taxas de desmatamento depende de como o crédito rural é utilizado. Se utilizado para aprimoramento das técnicas de produção e intensificação da produção por unidade de terra de produção agrícola, a restrição da concessão de crédito pode limitar os ganhos produtivos e, assim, gerar incentivos para que os produtores que buscam expandir sua produção migrem para novas áreas. Se, no entanto, o crédito é utilizado para expandir a produção extensiva (desmatar áreas florestadas para acomodar um número crescente de cabeças de gado, por exemplo), o resultado esperado da redução da concessão de crédito deve ser o decréscimo das taxas de desmatamento (Assunção et al., 2013). Em estudo que analisou os impactos da Resolução 3545, Assunção et al. (2013) evidenciam uma relação positiva e significativa entre a redução do desmatamento na Amazônia Legal e a redução de concessão de crédito rural.

Os resultados indicam que, na ausência da Resolução 3545, o desmatamento na região teria sido de $2783 \mathrm{~km}^{2}$ a mais do que o observado no período entre os anos de 2009 e 2011. Em 2010, por exemplo, o desmatamento teria totalizado $7398 \mathrm{~km}^{2}$, caso a resolução não tivesse sido introduzida (Assunção et al., 2013). No referido ano, o desmatamento observado na região foi de $5657 \mathrm{~km}^{2}$, evidenciando que houve resposta à redução na disponibilidade de crédito subsidiado, acarretando mudanças na alocação de recursos e, assim, ocasionando redução do desmatamento (Assunção et al., 2013).

Estima-se que aproximadamente $\mathrm{R}$ \$ 2,9 bilhões não foram disponibilizados entre os anos de 2008 e 2011 devido às restrições impostas pela Resolução 3545, representando a redução no financiamento para atividades pecuárias 90\% de tal diferença (Assunção et al., 2013). A implementação da Resolução 3545 levou à redução no número de grandes e médios contratos no setor da pecuária e ao aumento de pequenos contratos neste setor. Em relação às 
atividades agrícolas, os resultados demonstram que os impactos da Resolução 3545 foram significativos apenas para médios contratos (Assunção et al., 2013). Grandes produtores agrícolas não foram afetados pela política, possivelmente, devido ao fato de que estes podem alcançar os requisitos impostos pela Resolução 3545 com maior facilidade, seja por sua capacidade organizacional aprimorada ou por maior acesso aos recursos necessários para seguir o processo de regularização, pois tais produtores podem ter acesso a outras fontes de financiamento (Assunção et al., 2013).

Em relação aos impactos da redução de concessão de crédito rural ocasionada pela Resolução 3545 nas taxas de desmatamento, Assunção et al. (2013) demonstram que a medida implicou na redução de desmatamento nos municípios onde a criação de gado é a atividade econômica predominante. Já os coeficientes estimados para os municípios em que a agricultura é a atividade econômica predominante indicam que nestes a redução da concessão de crédito rural não ocasionou grandes impactos nas taxas de desmatamento. Uma explicação plausível para tal diferença reside no fato de que a criação de gado requer relativamente mais área do que a produção agrícola.

Além disso, deve-se considerar o fato de que a produção agrícola no país passou por diversos aprimoramentos tecnológicos, o que possibilitou o aumento da produção em bases intensivas e, nesse caso, mudanças em relação à disponibilidade de crédito rural não afetam significativamente o desmatamento (Assunção et al., 2013). Nas Figuras 14 e 15, observam-se as concessões de crédito rural observada e estimada ${ }^{7}$ para atividades pecuárias (boi) e agrícolas (soja), respectivamente, de acordo com Assunção et al. (2013).

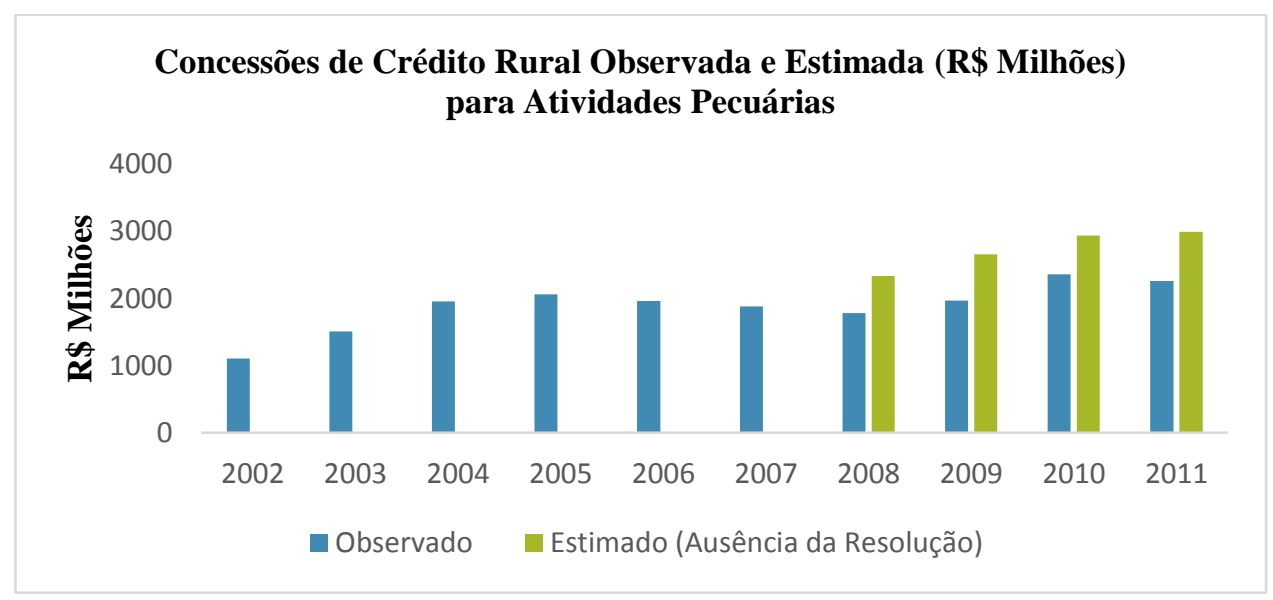

Figura 14: Concessões de crédito rural para atividades pecuárias, entre 2002 e 2011. Fonte: Assunção et al., 2013; BCB, 2014.

${ }^{7}$ Os números estimados foram calculados em simulações contrafactuais e referem-se a estimativas do que teria ocorrido na ausência da Resolução 3545/08 por Assunção et al. (2013). 


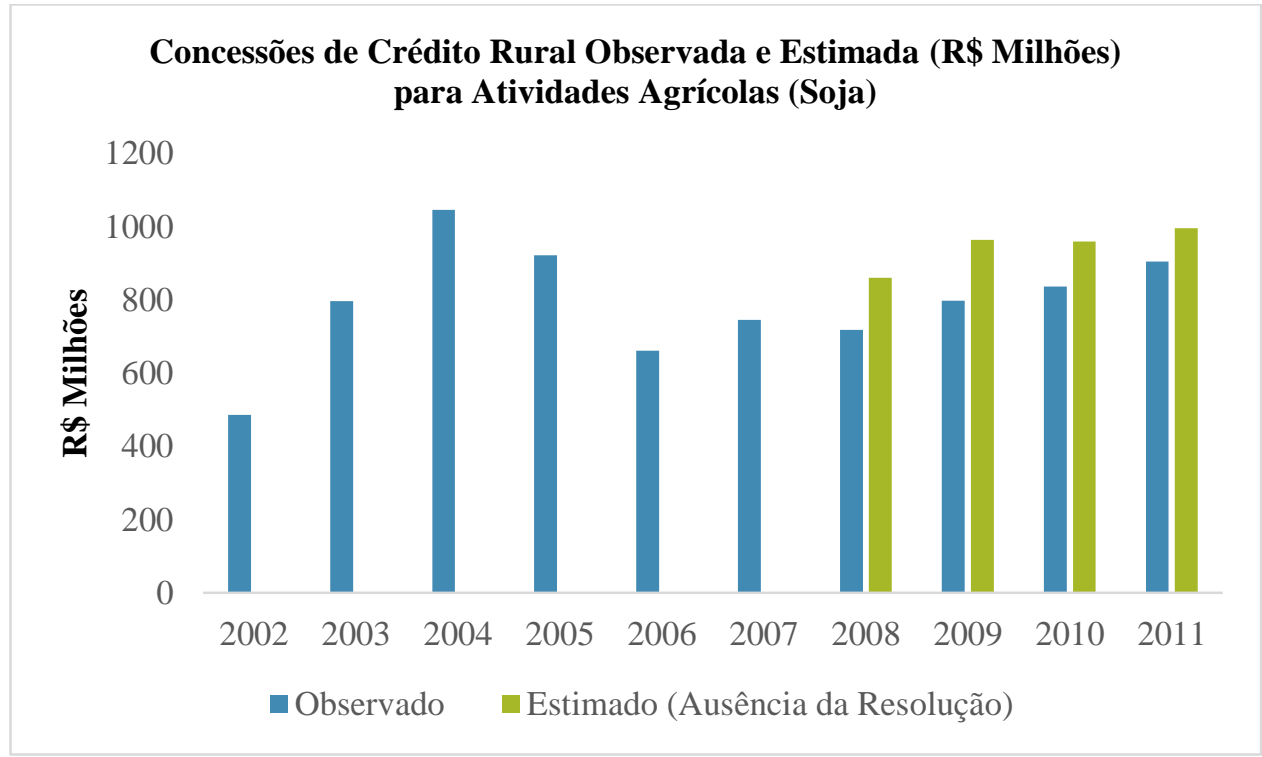

Figura 15: Concessões de crédito rural para atividades agrícolas (soja), entre 2002 e 2011. Fonte: Assunção et al., 2013; BCB, 2014.

Setzer (2014) e Valeriano (2014) afirmam que a partir da implementação da Resolução 3545 houve mudança comportamental comprovada nos municípios em que a concessão de crédito foi suspensa, o que comprova a efetividade da medida. Fearnside (2014), Moutinho (2014) e Soares-Filho (2014) apontam a restrição do crédito rural como medida chave para o combate ao aumento das taxas de desmatamento quando da recuperação dos preços das commodities de carne e soja, de 2008 em diante, conforme já mencionado. Mas Soares-Filho (2014) alerta para o fato de que apesar dos avanços alcançados, a restrição de crédito rural é uma política limitada, pois é necessário trabalhar com os produtores rurais para ajudá-los a atingir os critérios ambientais (fornecendo incentivos) ao mesmo tempo em que são criadas as restrições - o que ainda não ocorre.

\subsection{Os Impactos das Moratórias da SoJa E DA CARne E EMbargos COMERCIAIS}

Setzer (2014) argumenta que as moratórias e embargos vêm exercendo, cada vez mais, um papel expressivo. Soares-Filho (2014), no entanto, afirma que o papel das Moratórias e embargos comerciais não é tão claro. Argumenta que análises mais robustas são necessárias para identificar seus impactos. Para Soares-Filho (2014), o maior papel das Moratórias pode ser identificado como a criação de pressões sobre os maiores atores ligados às cadeias produtivas da soja e carne, mas ressalta que tais pressões ainda estão em sua fase inicial e caminhando lentamente. Para Moutinho (2014), é difícil quantificar a influência das moratórias e dos embargos comerciais. Fearnside (2014) afirma que as Moratórias e embargos 
comerciais não explicam a redução de desmatamento ocorrida no ano de 2008 , e sim a restrição de crédito rural; logo, a política de restrição de crédito tem um impacto muito maior e mais efetivo. Já Valeriano (2014) afirma que a questão de como o mercado vem encarando o tema é importante, citando o exemplo de um representante da rede de supermercados Wall Mart, que declarou que o consumidor busca saber se a carne vendida naquele supermercado é oriunda de áreas onde houve desmatamento ilegal, o que levou a cadeia de supermercados a criar grande interesse em ter conhecimento a respeito da origem da carne a ser vendida por eles, recusando os produtos oriundos de terras onde ocorreu o desmatamento ilegal. Ainda segundo Valeriano (2014), os embargos comerciais resultantes das Moratórias poderiam ser mais efetivos caso o IBAMA tivesse um programa de monitoramento de tais embargos, o que vem sendo desenvolvido pelo INPE.

Souza, Miziara \& Junior (2012) afirmam que os embargos a produtos oriundos de áreas desmatadas ainda não demonstraram efetividade na redução de desmatamento. Ruviaro, Barcellos \& Dewes (2013) argumentam que os sistemas de produção agrícola e pecuária devem se adaptar de forma a atender as demandas de consumidores que buscam a certeza de que os produtos adquiridos não são oriundos de áreas desmatadas.

Em 2008, o Ministério Público Federal do estado do Pará (MPF-PA) deu início a ações legais contra 20 fazendeiros que atuavam em desacordo com a legislação ambiental e 11 frigoríficos que compravam carne de tais fazendas; além disso, lançou a recomendação a 69 cadeias de supermercados para que não fossem realizadas compras de tais frigoríficos (Arima et al., 2014 apud MPF-PA, 2009). Tais ações foram articuladas à campanha do Greenpeace contra a compra de carne oriunda de fazendas onde as leis ambientais e trabalhistas não eram obedecidas. Através de tais ações coordenadas entre o Estado e a sociedade civil, 35 grandes cadeias de supermercado brasileiras e um grande número de compradores de outros produtos pecuários (como couro) deram fim às compras provenientes das propriedades irregulares em questão (Arima et al., 2014). Adicionalmente, a Associação Brasileira de Supermercados anunciou novos requisitos, aos fornecedores, para o certificado de origem dos produtos pecuários (Arima et al., 2014 apud Barreto \& Araújo, 2012) e aos fazendeiros foram solicitados planos detalhados para a restauração das áreas desmatadas. Em 2009, o MPF-PA ofereceu a suspensão de ações legais aos 11 frigoríficos citados acima, caso estes concordassem em realizar suas compras apenas de fazendas livres de embargo e registradas no CAR; em 2013, mais de 72 propriedades privadas (totalizando 20 milhões de hectares) no estado do Pará estavam registradas no CAR estadual, o que corresponde a quase $80 \%$ do total de área de propriedades privadas (Arima et al., 2014). Tais fatos demonstram 
que, embora muito lentamente e de forma ainda pouco efetiva, o elemento de mercado (embargos comerciais) pode induzir a mudanças comportamentais que podem vir a contribuir para a redução das taxas de desmatamento.

\subsection{OS IMPACTOS DO PPCDAM}

Valeriano (2014) afirma que o PPCDAm é força de monitoramento e fiscalização, elementos que tiveram grande impacto na redução da taxa de desmatamento na região. Destaca que os pontos fracos do Plano residem na ausência de fomentos a atividades sustentáveis rurais e na fraca presença de Estado. Para Stezer (2014), o PPCDAm também representa evoluções em relação ao fortalecimento das medidas de monitoramento e fiscalização da região Amazônica, mas enfatiza que deve-se levar em consideração a existência de uma agenda paralela à tal Política - o que explica a grande proporção de desmatamentos ilegais ainda verificados na região. Soares-Filho (2014) aponta o aprimoramento do monitoramento e fiscalização da região e a criação de aproximadamente 50 milhões de hectares em Unidades de Conservação como principais contribuições do PPCDAm à redução das taxas de desmatamento entre 2005 e 2013.

Moutinho (2014), afirma que o grande resultado do PPCDAm foi o de ocasionar um processo de aumento de discussão no âmbito governamental, e destaca o importante papel do Plano em relação à questão do aprimoramento do monitoramento da Amazônia e ao entendimento, a partir de análise dos dados do PRODES e DETER, a respeito dos fatores regionalizados de avanço do desmatamento. Moutinho (2014) cita, ainda, que outro aspecto positivo do Plano é o de trazer para discussão a questão do fomento e incentivos a atividades ou comportamentos sustentáveis em relação à floresta. No entanto, destaca que o PPCDAm é um programa com muitas falhas de implementação e que o eixo comando-e-controle já se encontra em seu limite.

Segundo Fearnside (2014), a medida advinda do PPCDAm de expansão e criação de novas Áreas Protegidas merece destaque devido a seus impactos positivos, mas salienta o fato de estar havendo a estagnação de tal medida. Cita como exemplo que, no ano de 2008, houve a paralização da criação de novas Unidades de Conservação no estado do Amazonas, além da existência de movimentos - como a PEC $215^{8}$ - que dificultam a criação de novas Áreas

\footnotetext{
${ }^{8}$ Proposta de Emenda Constitucional que visa a transferência da competência da União na demarcação
} de Terras Indígenas para o Congresso Nacional; possibilitar a revisão das terras já demarcadas e tornar possível mudanças nos procedimentos e critérios para a demarcação de áreas. 
Protegidas em nível federal. Fearnside (2014) afirma, ainda, que o programa governamental é uma iniciativa necessária, mas que não se pode inferir que a situação de desmatamentos na Amazônia brasileira encontra-se sob controle.

\subsubsection{A Criação e Expansão de Áreas Protegidas}

A expansão da rede de Áreas Protegidas na Amazônia Brasileira é citada como uma das principais contribuições das medidas implementadas pelo PPCDAm para a redução das taxas de desmatamento na região. Áreas Protegidas são definidas como áreas públicas às quais são aplicadas restrições relacionadas ao uso do solo, objetivando a garantia de proteção aos ecossistemas nativos. Na Amazônia Brasileira, as Áreas Protegidas incluem os Territórios Indígenas (TIs), as Áreas Militares e Unidades de Conservação (UCs) (Soares-Filho et al., 2010). O Sistema Nacional de Unidades de Conservação (SNUC) define as UCs como "espaços territoriais e seus recursos ambientais, incluindo as águas jurisdicionais, com características naturais relevantes, legalmente instituídos pelo Poder Público, com objetivos de conservação e limites definidos, sob regime especial de administração, ao qual se aplicam garantias adequadas de proteção" e as classifica em dois grupos, conforme descritos na Tabela 4. No que se refere a sua gestão, as UCs podem ser Federais ou Estaduais (Brasil, 2000). Em relação aos TIs, a Constituição Federal de 1988 define: "são terras tradicionalmente ocupadas pelos índios as por eles habitadas em caráter permanente; as utilizadas para suas atividades produtivas; as imprescindiveis à preservação dos recursos ambientais necessários a seu bem-estar; e as necessárias a sua reprodução física e cultural, segundo seus usos, costumes e tradições.” (Brasil, 1988). As TIs consistem na categoria mais eficiente de Área Protegida, destacando-se o papel do complexo Xingu/Jarina/Menkragnotí/Kayapó/Baú na inibição de desmatamento em uma área de fronteira agrícola (Soares-Filho et al., 2010).

\begin{tabular}{|c|c|c|}
\hline \multicolumn{3}{|c|}{ Unidades de Conservação } \\
\hline $\begin{array}{l}\text { Atividades } \\
\text { Permitidas }\end{array}$ & $\begin{array}{l}\text { Unidades de Proteção Integral } \\
\text { Pesquisa científica e, desde que haja prévia } \\
\text { autorização do órgão responsável, turismo e } \\
\text { atividades de educação ambiental. }\end{array}$ & $\begin{array}{l}\text { Uso Sustentável } \\
\text { Turismo; educação ambiental e } \\
\text { extração de produtos florestais } \\
\text { madeireiros e não madeireiros, } \\
\text { com base no manejo sustentável } \\
\text { e de acordo com o plano de } \\
\text { manejo da unidade. }\end{array}$ \\
\hline
\end{tabular}


Estação Ecológica (Esec), Reserva Biológica (Rebio), Parque Nacional/Estadual (Parna/PES),

Categorias
Área de Proteção Ambiental (APA), Área de Relevante Interesse Ecológico (ARIE), Floresta Nacional/Estadual (Flona/Flota), Reserva Extrativista (Resex), Reserva da Fauna (RF), Reserva de Desenvolvimento Sustentável (RDS), Reserva Particular do Patrimônio Natural (RPPN).

Permitida às populações denominadas tradicionais, desde que realizem atividades sob regime de manejo sustentável.

Tabela 4: Classificação de Unidades de Conservação. Fonte: Brasil, 2000.

Soares-Filho et al. (2010) estimam que a criação de novas Áreas Protegidas na Amazônia Brasileira a partir de 2002 foi responsável por $37 \%$ do declínio de $13.400 \mathrm{~km}^{2}$ na taxa de desmatamento observado entre os anos de 2004 e 2006, afirmando que não foi encontrada dependência espacial entre regiões em que houve a expansão de tais áreas e as regiões em que as taxas de desmatamento aumentaram. Tais resultados demonstram o papel das Áreas Protegidas tanto em deter o desmatamento em nível local, quanto em influenciar a redução das taxas de desmatamento em nível regional, já que sua criação pode desencorajar a ação de grileiros em suas proximidades (Soares-Filho et al., 2010). Soares-Filho (2014) destaca que a criação de Áreas Protegidas em torno de estradas tem sido fundamental para o combate à grilagem - pela retirada de grande área florestal do mercado especulativo de terra em seus entornos, citando o Plano BR-163 Sustentável (que deu origem à criação de FLONAS e Áreas Protegidas em torno de tal estrada) como um dos mais importantes neste contexto. Apesar de Áreas Protegidas virem sendo criadas antes da implantação do PPCDAm, este alavancou a expansão das mesmas, instituindo a criação de mais de 50 milhões de hectares em Unidades de Conservação federais e estaduais, majoritariamente localizadas nas áreas sob pressão do desmatamento (PPCDAm, 2012).

Deve-se atentar, no entanto, ao fato de que vem aumentando a frequência de desmatamentos dentro de Áreas Protegidas, especialmente nas Unidades de Conservação de Uso Sustentável. Uma vasta rede de estradas ilegais avança sobre tais áreas; boa parte dessas vias está associada à exploração madeireira ilegal (Veríssimo et al., 2011) e podem ocasionar a ampliação de conflitos pela posse de terra (Souza et al., 2005). Barreto, Araújo \& Brito (2009) analisaram 46 crimes ambientais e concluíram que 59\% ocorreram em nove Unidades de Conservação federais (30,5\% em Unidades de Proteção Integral e 28,5\% em Unidades de Uso Sustentável) e $41 \%$ em onze Terras Indígenas. Stezer \& Morelli (2008) alertam para a 
incidência de incêndios florestais em áreas protegidas, apontando que 91,5\% de 674 áreas analisadas eram afetadas pela incidência de fogo. No Parque Nacional do Xingu, grupos indígenas percebem que a intensidade dos incêndios florestais durante períodos de seca são mais intensos e afetam maiores áreas da floresta. (Brando et al., 2013 apud Schwartzman, 2013).

Também é importante destacar que embora a medida de criação de Áreas Protegidas seja eficiente na inibição do desmatamento, tal medida pode ser considerada como frágil, pois a ocupação irregular de tais áreas e a instalação de projetos de infraestrutura têm provocado iniciativas para que seja reduzida ou mesmo retirada a proteção legal de Áreas Protegidas na Amazônia Brasileira.

Até junho de 2010, cerca de 5 milhões de hectares de Áreas Protegidas foram desafetados e outros 8,6 milhões eram objeto de projetos de leis e ações judiciais (Martins et al., 2014). Os governos em nível federal e estadual têm optado pela desafetação das áreas ocupadas, evitando a remoção e indenização de ocupantes. A desafetação também vem ocorrendo quando as áreas apresentam potencial econômico atraente, especialmente em se tratando de geração de hidroeletricidade. No ano de 2010, o total de áreas desafetadas foi de aproximadamente um milhão de hectares (Martins et al., 2014). Martins et al (2014) afirmam ainda que o desmatamento aumentou significativamente nas áreas desafetadas, destacando que, além do dano direto ocasionado, a redução da área ou do grau de proteção de Áreas Protegidas enfraquece a credibilidade da política de conservação e de direitos sociais de populações indígenas. As novas invasões às FLONAS de Roraima e do Bom Futuro foram estimuladas pelas reduções às Áreas Protegidas ocorridas em 2009 e 2010 (Martins et al., 2014).

Azevedo (2014) argumenta que até o ano de 2009, a ocorrência de desmatamento em áreas protegidas era bem menos expressiva (na ordem de 3\% a 6\%) do que o verificado após 2009 (ordem de 20\% a 30\%). Quando houve a desafetação de grandes áreas em 2010 (em grande parte destinada a realização de estudos de viabilidade de construção de usinas hidrelétricas), o sinal dado ao mercado foi de que a redução de áreas protegidas é possível quando há interesse econômico (Azevedo, 2014). Além disso, pressões relacionadas à ocupação de terra também podem ocasionar a redução de áreas protegidas, como aconteceu no DSF da BR-163 (Azevedo, 2014; Valeriano, 2014). Setzer (2014) alerta ainda para o fato de que diversos focos de queimada são detectados em áreas protegidas e que estradas ilegais vêm também adentrando tais áreas. 
Verifica-se, então, que apesar da medida de criação e expansão de áreas protegidas ter apresentado resultados positivos no âmbito do controle do desmatamento, as respostas políticas recentes às pressões socioeconômicas exercidas em tais áreas vêm impactando negativamente tal controle.

\subsubsection{O Aprimoramento do Monitoramento por Satélites da Amazônia Legal}

Assunção et al. (2013b) afirmam que a implementação do Sistema DETER foi o principal motor de desaceleração das taxas de desmatamento na Amazônia Brasileira e estimam que as políticas de comando-e-controle baseadas em tal Sistema impediram o desmatamento de mais de $59.500 \mathrm{~km}^{2}$ de floresta amazônica, entre os anos de 2007 e 2011, devido à ação reforçada dos agentes do IBAMA na região, ressaltando que, em tal cenário, não houve o comprometimento da produção agrícola.

Rajão \& Vurdubakis (2013) afirmam, também, que a introdução do Sistema DETER e das tecnologias a este Sistema associadas trouxeram ganhos expressivos por terem possibilitado um crescimento exponencial no número de multas aplicadas pelo IBAMA quando da verificação de ocorrência de desmatamento ilegal. Tal processo, baseado em tecnologia digital, traz resultados mais resilientes contra institutos legais: os advogados que tentam legalmente retirar as multas aplicadas aos fazendeiros utilizam-se de argumentos a respeito do "caráter" do agente do IBAMA - dado à existência de escândalos de corrupção envolvendo os agentes, não é incomum que um advogado argumente que a multa imposta por ocorrência de desmatamento era, de fato, uma tentativa de extorsão por parte de um agente corrupto a fazendeiros honestos. As inspeções realizadas em localidades onde houve mudança de uso do solo detectada pelo Sistema DETER anula tal questão, pois as mesmas têm origem a partir de dados de satélite, e não da ação aleatória do agente do IBAMA (Rajão \& Vurdubakis, 2013). Além disso, o cálculo da área desmatada e da multa a ser aplicada (proporcional ao desmatamento ocorrido) é realizado de forma precisa a partir da obtenção das imagens de satélite; assim, os advogados não podem argumentar que a área de infração e a multa aplicada foram mal calculadas (Rajão \& Vurdubakis, 2013).

Valeriano (2014) afirma que o ano de 2007 foi o marco a partir do qual foi dispensada maior atenção aos dados gerados pelo DETER por parte do IBAMA; em tal ano, o Sistema detectou o aumento de degradação e desmatamento no estado do Mato Grosso, e fez-se necessária a comunicação desse fato antes do lançamento dos dados do PRODES - INPE, para que ações imediatas fossem tomadas de forma a impedir a continuação da tendência de aumento das mudanças de uso do solo ilegais. A partir da tomada de tais ações, que 
exerceram resultado positivo, o IBAMA passou a coordenar suas operações de campo de forma mais eficientemente articulada à divulgação dos dados gerados pelo Sistema DETER. Tais ações tornaram-se mais efetivas e geraram um entendimento, por parte dos proprietários de terra, da existência de vigilância e fiscalização rigorosas, o que resultou em uma mudança comportamental e fragmentação do desmatamento - que passou a ser feito em parcelas menores, diluído em um espaço de tempo maior. A partir do ano de 2006, a contribuição relativa da classe de polígonos inferior a 25ha (área mínima mapeada pelo Sistema DETER) passou a se tornar mais expressiva, tendo alcançado cerca de 45\% em tal ano (PPCDAm, 2012), conforme pode ser observado na Figura 16, que apresenta a evolução da contribuição relativa $(\%)$ dos polígonos com área inferior a 25ha para o desmatamento total anual, entre 2005 e $2012 .{ }^{9}$

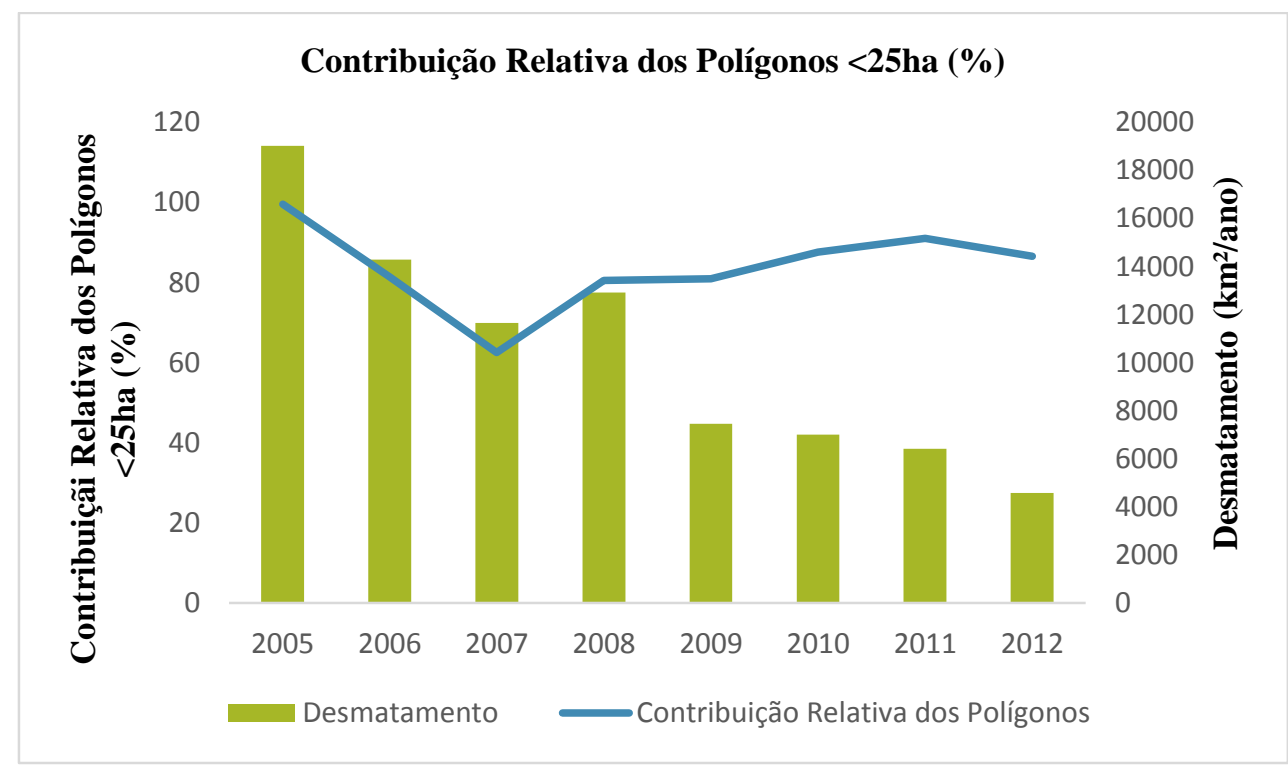

Figura 16: Contribuição relativa dos polígonos de desmatamento <25ha para o total anual desmatado entre 2005 e 2012. Fonte: INPE-PRODES, 2014.

É expressivo o aumento da contribuição dos polígonos de desmatamento inferiores a 25 hectares após o ano de 2007 - ano apontado como a partir do qual os dados gerados pelo Sistema DETER passaram a exercer maior influência nas ações de combate ao desmatamento, conforme mencionado anteriormente. Em todos os estados da Amazônia Legal tal tendência é observada (INPE-PRODES, 2014), conforme Figuras 17 - 25.

\footnotetext{
${ }^{9}$ Dados disponíveis apenas para este período.
} 


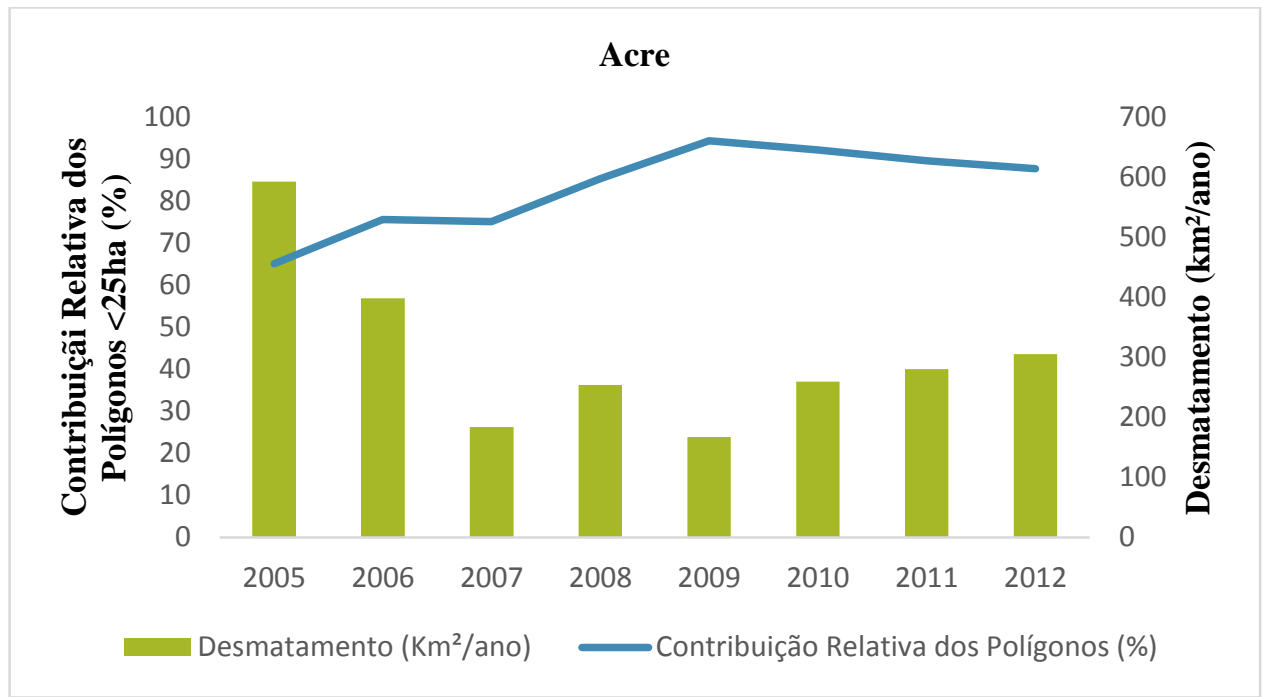

Figura 17: Contribuição relativa dos polígonos de desmatamento <25ha para o total anual desmatado entre 2005 e 2012, no Acre. Fonte: INPE-PRODES, 2014.

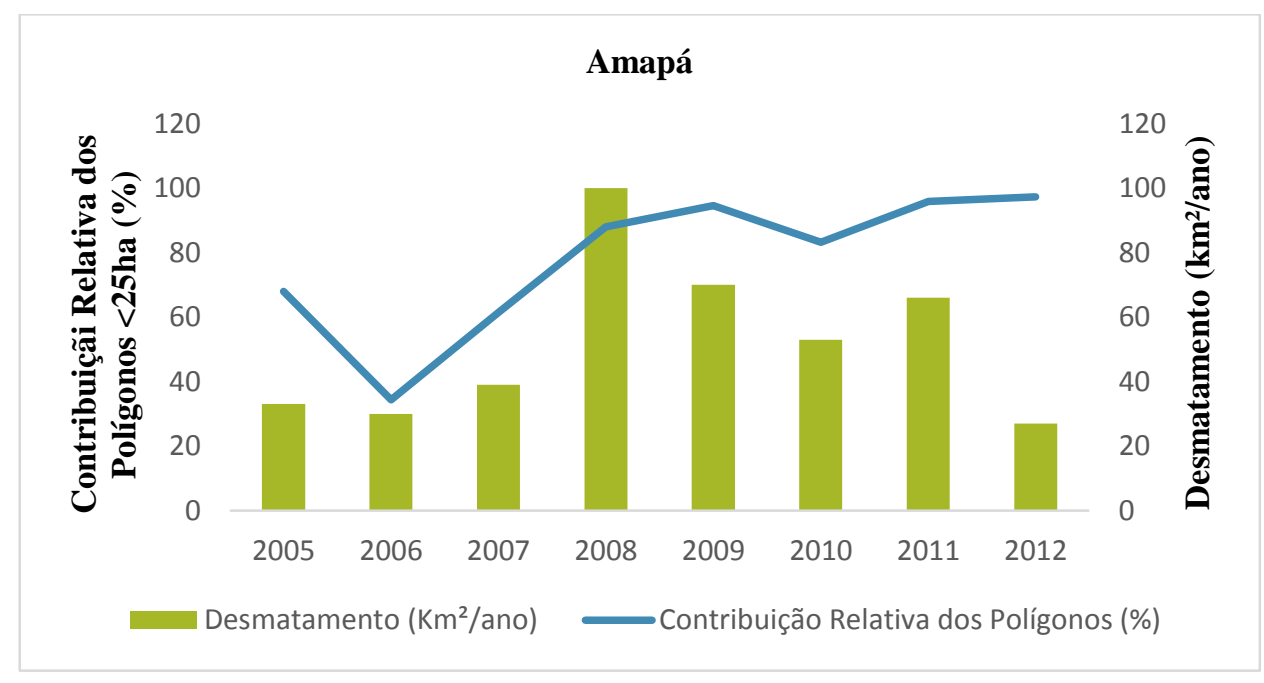

Figura 18: Contribuição relativa dos polígonos de desmatamento <25ha para o total anual desmatado entre 2005 e 2012, no Amapá. Fonte: INPE-PRODES, 2014.

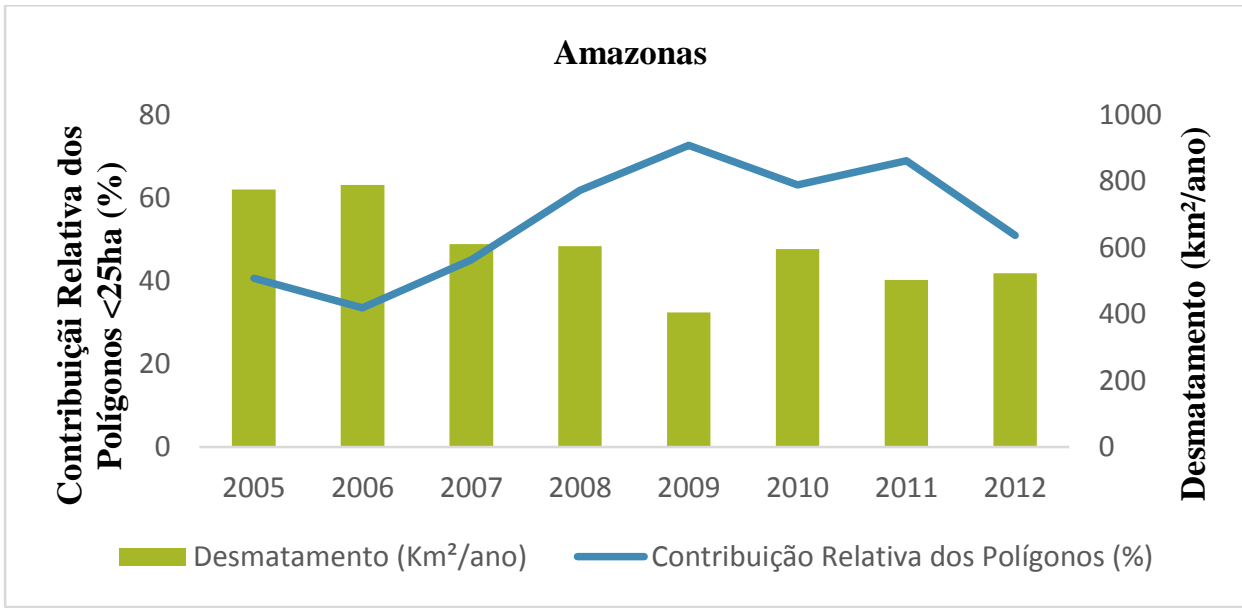

Figura 19: Contribuição relativa dos polígonos de desmatamento <25ha para o total anual desmatado entre 2005 e 2012, no Amazonas. Fonte: INPE-PRODES, 2014. 


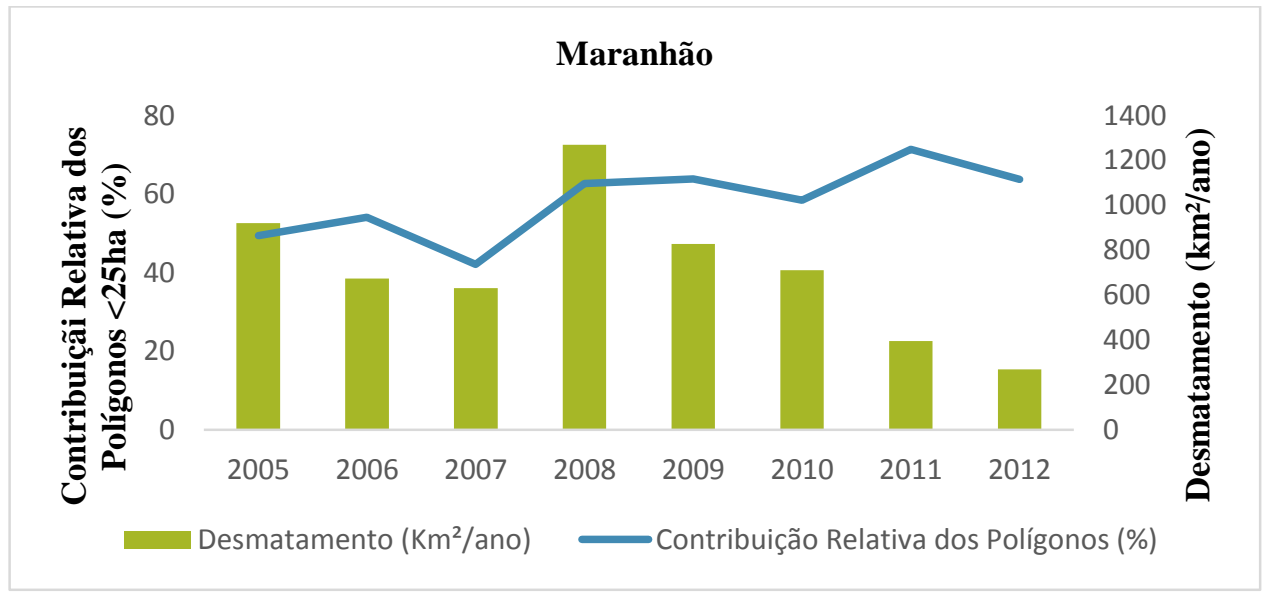

Figura 20: Contribuição relativa dos polígonos de desmatamento <25ha para o total anual desmatado entre 2005 e 2012, no Maranhão. Fonte: INPE-PRODES, 2014.

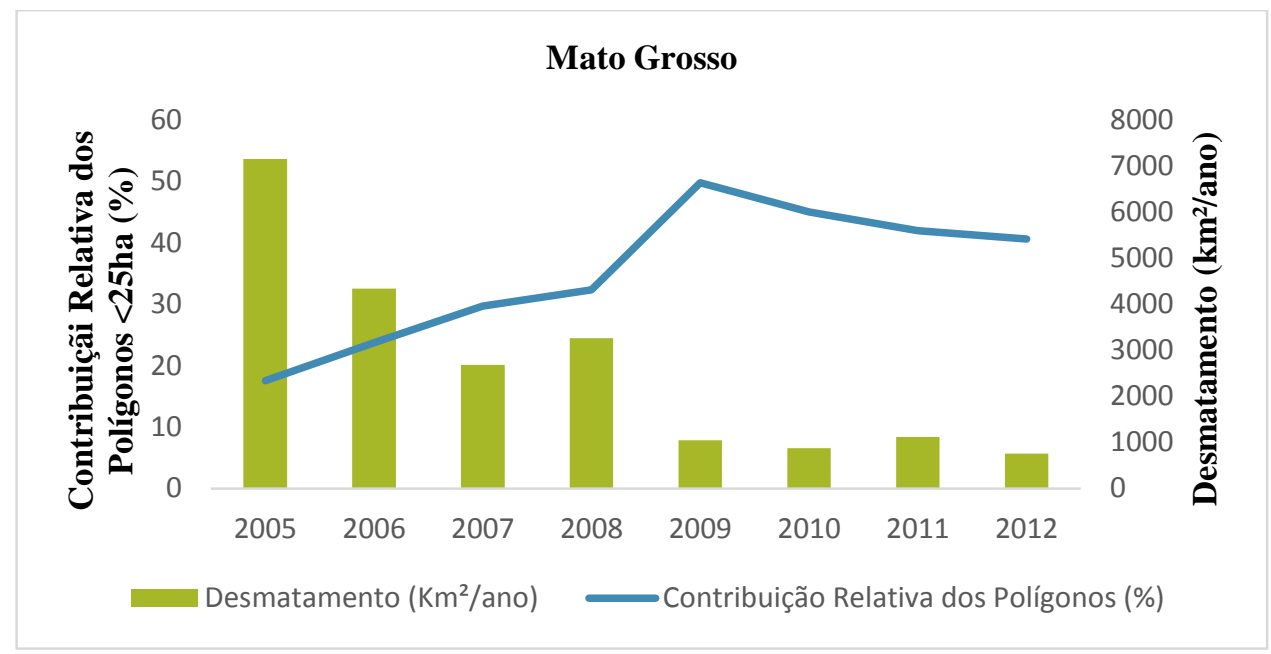

Figura 21: Contribuição relativa dos polígonos de desmatamento <25ha para o total anual desmatado entre 2005 e 2012, no Mato Grosso. Fonte: INPE-PRODES, 2014.

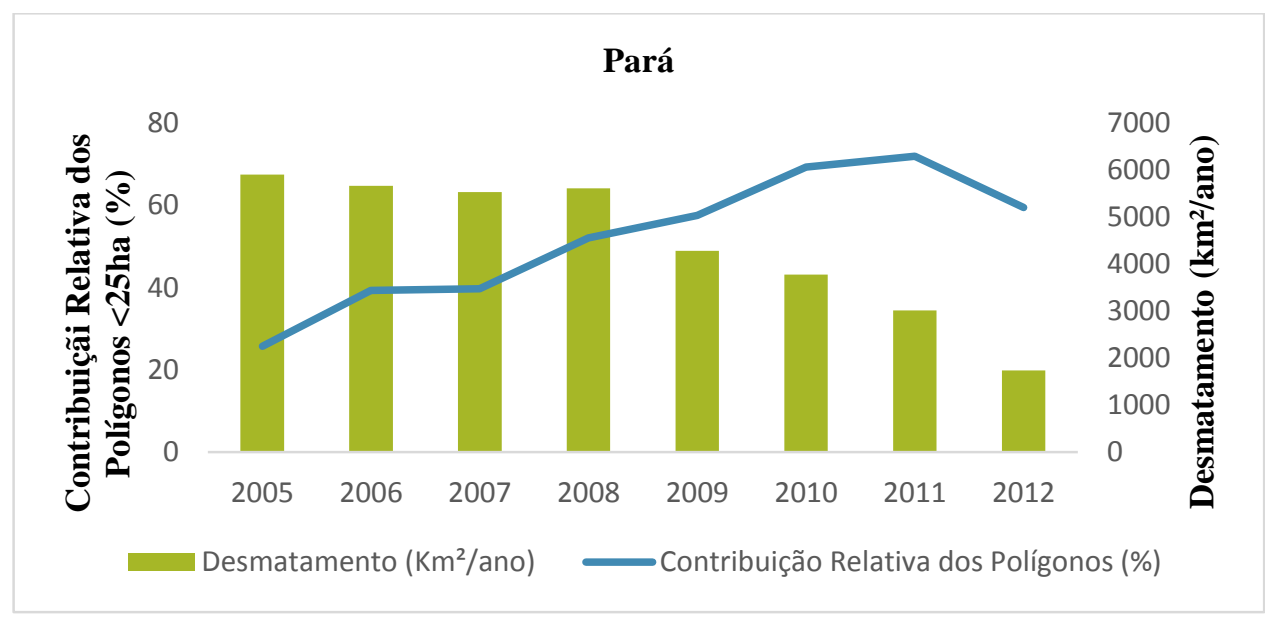

Figura 22: Contribuição relativa dos polígonos de desmatamento <25ha para o total anual desmatado entre 2005 e 2012, no Pará. Fonte: INPE-PRODES, 2014. 


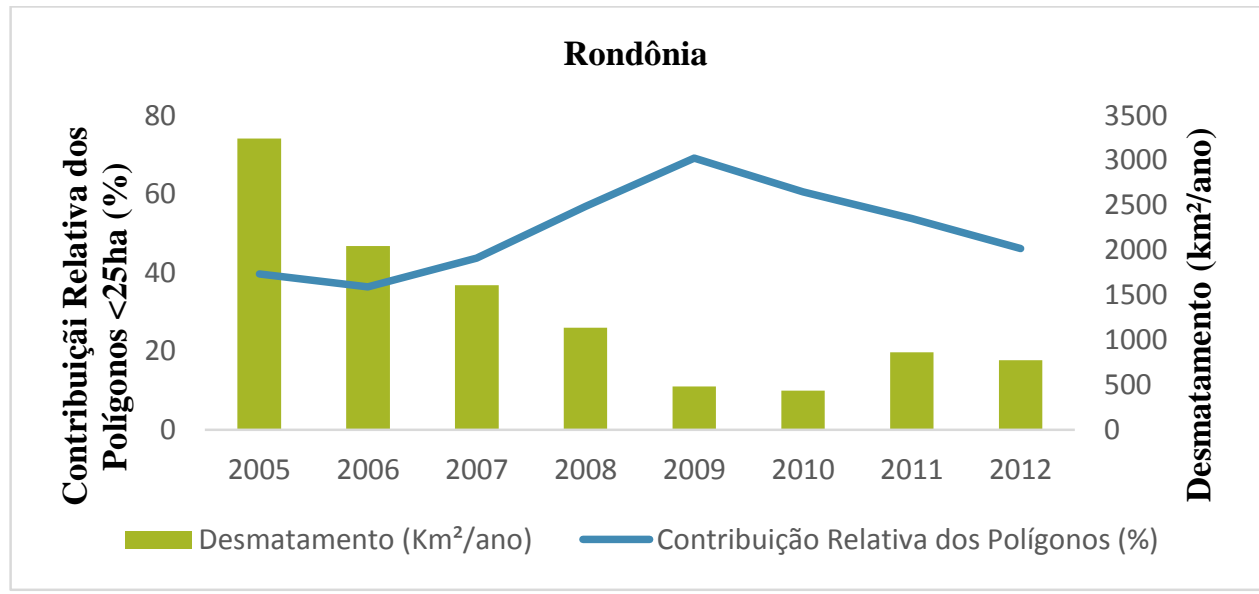

Figura 23: Contribuição relativa dos polígonos de desmatamento <25ha para o total anual desmatado entre 2005 e 2012, em Rondônia. Fonte: INPE-PRODES, 2014.

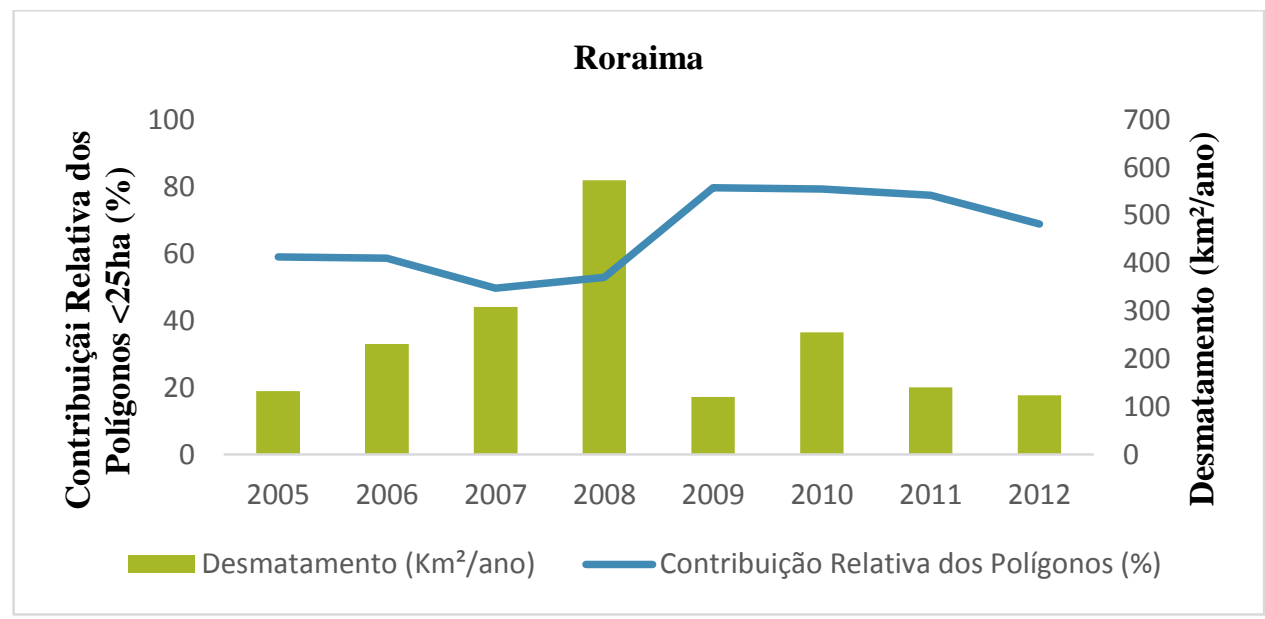

Figura 24: Contribuição relativa dos polígonos de desmatamento <25ha para o total anual desmatado entre 2005 e 2012, em Roraima. Fonte: INPE-PRODES, 2014.

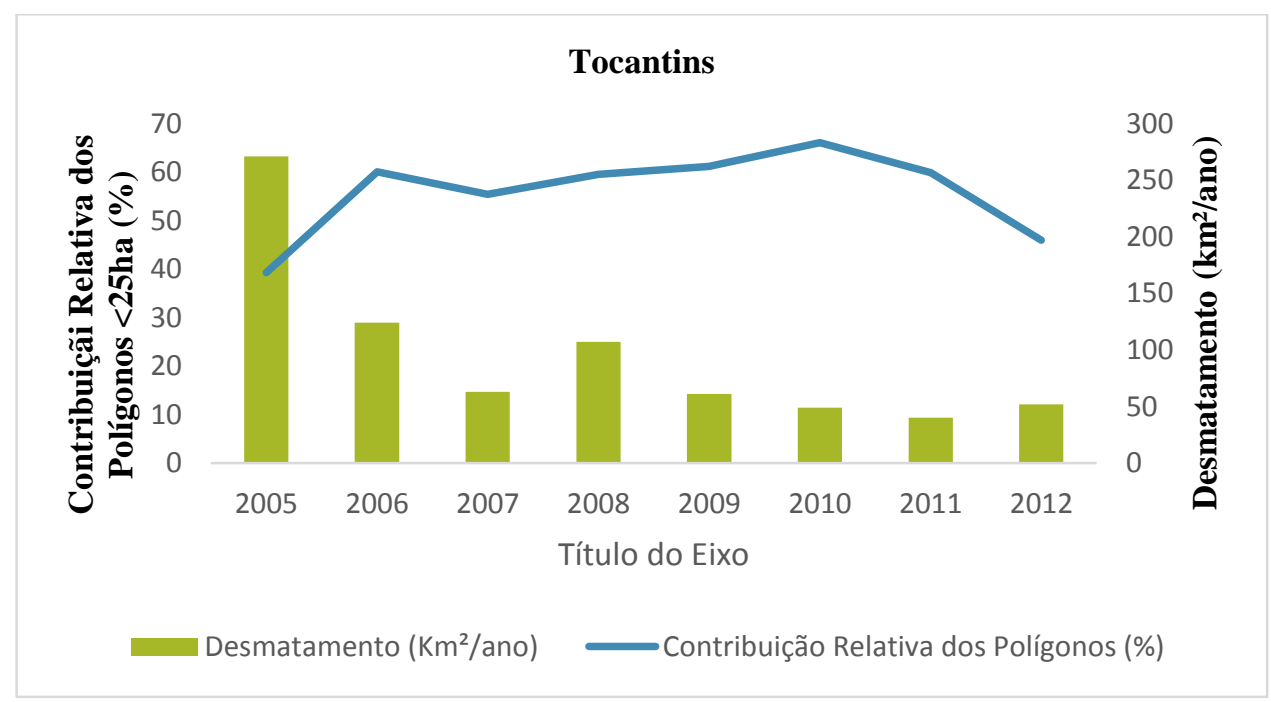

Figura 25: Contribuição relativa dos polígonos de desmatamento <25ha para o total anual desmatado entre 2005 e 2012, em Tocantins. Fonte: INPE-PRODES, 2014. 
Rajão (2014) afirma que ao se fazer uso de uma tecnologia estabelecida que fornece dados, gerando informações acessíveis a todos, o processo de desmatamento torna-se realidade constituída, algo concreto que tem tangência política. A partir disso, diversas medidas de combate à pratica podem ser elaboradas e aplicadas, fazendo com que o grande custo deixe de ser o maior entrave para o desmatamento de grandes áreas. Azevedo (2014) afirma que o Sistema DETER funciona como polo irradiador de ações, estando presente em vários lugares ao mesmo tempo e tendo sido utilizado para diversas finalidades. Segundo Azevedo (2014), com os dados gerados pelo DETER, é possível que ações sejam tomadas mais rapidamente, o que foi fundamental no segundo semestre de 2007 , quando houve sinal de aumento de desmatamento.

Foi a partir dos dados gerados pelo Sistema DETER que foi detectada, no segundo semestre de 2007, a necessidade da criação da lista de municípios prioritários onde exigências adicionais que visam o combate ao desmatamento devem ser aplicadas. Conforme descrito no Capítulo 2, o Decreto 6321/07 instituiu a identificação de tais municípios prioritários. Na Figura 26, pode-se observar como se deram as dinâmicas de desmatamento nos referidos municípios entre o ano de 2007 (ano em que foram definidos) e 2013.

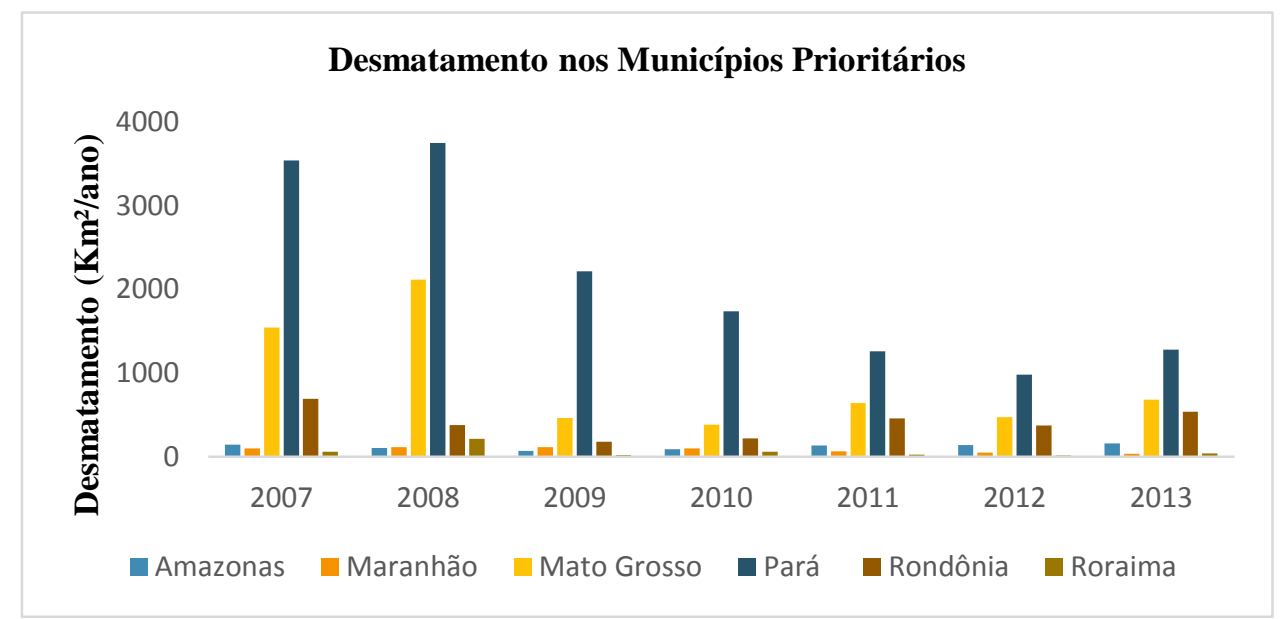

Figura 26: Desmatamento nos Municípios Prioritários, entre 2007 e 2013. Fonte: INPE-PRODES, 2014.

Lima et al. (2009) afirmam que, embora ainda seja necessária a realização de análises estatísticas robustas, as medidas oriundas do Decreto 6321/07 tiveram grande impacto na contenção do aumento de desmatamento verificado no segundo semestre de 2007. Os autores argumentam que, na ausência da política, o aumento do desmatamento verificado no ano de 2008 teria sido ainda mais expressivo e que tal tendência seria mantida nos anos seguintes.

A restrição de concessão de crédito rural e os embargos às propriedades onde é detectado desmatamento ilegal são citados como principais medidas de combate ao 
desmatamento quando da recuperação dos preços das commodities de soja e carne de boi; ambas medidas têm raízes no Decreto 6321/07. Dessa forma, torna-se claro que o papel do Sistema DETER não vem sendo apenas o de gerar ciência aos agentes desmatadores de que suas ações vêm sendo monitoradas (e assim gerando mudanças comportamentais); os dados gerados pelo Sistema DETER em 2007 deram origem às medidas citadas pelos atores entrevistados como as mais importantes para a reversão da tendência de aumento de desmatamento verificada em 2008 e manutenção da tendência de redução observada até 2013. Além disso, Azevedo (2014) cita também que a definição de Áreas Protegidas também é associada ao DETER.

\subsubsection{O Aprimoramento das Medidas de Fiscalização na Amazônia Legal}

Em relação ao aprimoramento da fiscalização na região, Setzer (2014), Valeriano (2014) e Azevedo (2014) afirmam que um alto nível de eficácia deve ser atribuído às ações de fiscalização da Polícia Federal. Moutinho (2014) argumenta que as medidas de fiscalização deixaram de ser efetivas a partir da descentralização da gestão ambiental em 2006, quando a responsabilidade em relação à mesma foi repassada aos estados e, em alguns casos, aos municípios. Isso ocorreu sem que houvesse um repasse de recursos ou capacitação técnica, mas destaca que a fiscalização será sempre importante, desde que seja bem planejada e realizada de forma estratégica, ressaltando que esta é uma medida muito mais emergencial do que de prevenção. Para Moutinho (2014), o PPCDAm não fez o planejamento da intervenção da fiscalização de forma adequada e a fiscalização emergencial já não é mais efetiva. Para Soares-Filho (2014), a articulação da fiscalização a nível federal foi eficaz, mas também argumenta que quando houve a descentralização das ações, perdeu-se em eficácia. Na maioria dos estados, se tem uma estrutura sucateada e os sistemas não são transparentes. Fearnside (2014) defende que as medidas de fiscalização são medidas importantes, porém, limitações permanecem ainda relacionadas a tais ações, citando como exemplo que, no Pará, existiu um período em que ordens eram dadas aos agentes de fiscalização para que estes não agissem no caso de reação por parte de grileiros.

Embora falhas ainda permeiem as medidas de fiscalização para o combate de desmatamento ilegal, pode-se afirmar que partir do reforço das mesmas, impulsionado pelo aprimoramento do sistema de monitoramento em funcionamento, os agentes desmatadores passaram a ter ciência de que suas ações eram rigidamente monitoradas e agilmente detectadas, o que ocasionou mudanças comportamentais. 


\subsection{IMPACTOS DO CADASTRO AMBIENTAL RURAL}

Azevedo et al. (2014) analisaram os impactos do CAR estadual no Pará e em Mato Grosso, entre os anos de 2008 e 2012, objetivando identificar os efeitos da implementação de tal ferramenta sobre as dinâmicas de desmatamento. Os resultados mostram-se heterogêneos. $\mathrm{O}$ estudo afirma que nas pequenas propriedades (até quatro Módulos Fiscais ${ }^{10}$ ) verificou-se a redução significativa da derrubada da floresta após ingresso no CAR. Tal fato ocorreu tanto em Mato Grosso (2009 e 2010) quanto no Pará (2008 a 2011) (Azevedo et al., 2014). Em relação às médias propriedades (quatro a quinze Módulos Fiscais), em Mato Grosso, verificou-se aumento substancial de desmatamento após a realização do Cadastro. No Pará, houve redução (Azevedo et al., 2014). Já as grandes propriedades, superiores a quinze Módulos Fiscais, apresentaram, em quase todos os anos analisados, aumento no desmatamento após a entrada no CAR em ambos os Estados (Azevedo et al., 2014). Ressaltase que no caso das pequenas propriedades, com o tempo, o efeito do CAR na redução do desmatamento diminuiu em ambos os estados, sugerindo sua incapacidade em coibir o desmatamento de forma sustentada; após a retirada dos municípios da "lista negra", parece perder-se o foco em relação ao combate ao desmatamento posterior nas propriedades cadastradas (Azevedo et al., 2014).

Segundo Azevedo et al. (2014), o aumento do desmatamento nas propriedades com CAR pode ser explicado, em parte, pelo crescimento do desmatamento de áreas menores do que aquelas detectadas pelas imagens de satélites. Tal fato sugere que a maioria do desmatamento realizado por proprietários que ingressaram no CAR é realizada sob a expectativa de que os órgãos de controle ignoram pequenos desmatamentos. No entanto, Azevedo et al. (2014) apontam que também foi possível observar desmatamentos ilegais acima de 300 ha em Mato Grosso (municípios de São José do Xingu, Nova Ubiratã e São Félix do Araguaia) e Pará (municípios de Santana do Araguaia, Ulianópolis, Moju, São Félix do Xingu, Bannach, Almeirim e Cumaru do Norte). Isso indica a persistência da existência de agentes desmatadores que apostam na incapacidade dos órgãos ambientais em punirem efetivamente os ilícitos ambientais (Azevedo et al., 2014).

${ }^{10}$ Módulo Fiscal: Unidade de medida fixada diferentemente para cada município de acordo com a Lei $n^{\circ}$ 6.746/79, que leva em conta o tipo de exploração predominante no município; a renda obtida com a exploração predominante; outras explorações existentes no município que, embora não predominantes, sejam expressivas em função da renda ou da área utilizada. 
Enfatiza-se, no entanto, que o desmatamento em propriedades que ingressaram no CAR corresponde a uma pequena proporção da área total desmatada em Mato Grosso $(14,0 \%)$ e no Pará (6,8\%). Além disso, somente 19,4\% e 9,2\% das propriedades incluídas no CAR no Pará e Mato Grosso, respectivamente, realizaram o desmatamento no período analisado (Azevedo et al., 2014).

As experiências analisadas nos estados de Mato Grosso e do Pará, então, evidenciaram que o sucesso da implementação do CAR requer o aprimoramento das medidas de monitoramento, fiscalização e punição (quando da ocorrência de desmatamento ilegal) nas propriedades cadastradas junto ao sistema. Segundo entrevistas realizadas por Azevedo et al. (2014), servidores estaduais sugeriram que

O governo, atualmente, não realiza, por falta de pessoal e infraestrutura, o monitoramento e a responsabilização de forma sistemática daqueles que desmatam ilegalmente, apesar de estarem registrados no CAR. Além disso, foi notado o temor entre os gestores públicos estaduais e municipais de que a aplicação de multas possa induzir produtores, ainda sem registro, a não o obter (Azevedo et al., 2014).

Logo, além do aprimoramento estrutural para maior controle sobre o desmatamento nas propriedades com CAR, é fundamental que o receio de que a aplicação de multas iniba os produtores a realizarem o cadastro de seus imóveis. Dessa forma, também se faz necessário que incentivos e benefícios sejam concedidos aos proprietários que ingressam no CAR e, principalmente, aos que se mantêm em conformidade com a legislação após a realização do cadastro de seus imóveis, conforme apontado por Azevedo et al. (2014). Tais incentivos devem estar atrelados aos mercados e às políticas públicas que estimulam cadeias produtivas livres de desmatamento ilegal e estejam de acordo com as legislações ambientais. Há que se inibir o comportamento dos proprietários de terra que deriva da noção de que suas práticas de desmatamento ilegal, especialmente de pequenas áreas, não são detectadas e passíveis à punição efetiva. A sensação de impunidade deve ser eliminada, de forma a tornar possível os efeitos positivos da implementação do CAR de forma homogênea e sustentada em todos os Estados brasileiros. Para que isso ocorra, Moutinho (2014) ressalta que medidas adicionais, em termos de formulação de legislação ambiental e de novos procedimentos de fiscalização, são necessárias.

\subsection{DINÂMICAS RELACIONADAS AO SETOR MADEIREIRO}


Apesar do reforço das medidas de combate aos processos de desmatamento ilegal, a ilegalidade no setor ainda é significativa. Esta razão, aliada ao fato de que tal setor é extremamente dinâmico e difuso, torna difíceis o monitoramento e o acesso a dados concretos relacionados às atividades de exploração madeireira.

Em relação ao consumo de madeira em tora na Amazônia Legal, os dados mais recentes disponíveis 11 apontam uma redução significativa entre 2004 e 2009. Em 2004, o consumo de toras foi de 24,5 milhões de metros cúbicos; em 2009, foi de 14,2 milhões de metros cúbicos (Imazon, 2010). Tal queda no consumo de madeira em tora de cerca de 10 milhões de metros cúbicos entre 2004 e 2009 tem três causas principais: (i) substituição da madeira tropical por produtos; (ii) aumento na fiscalização; e (iii) crise econômica internacional em 2009, afetando as exportações. Os produtos concorrentes ao qual se refere o item (i) são forros de PVC, esquadrias de alumínio, formas de metal, MDF (produzido a partir de madeira de reflorestamento) e madeiras de reflorestamento em geral (Imazon, 2010 apud Sobral et al., 2002; Pereira et al., 2010). Em relação ao aumento na fiscalização, destacam-se as ações do IBAMA realizadas de 2005 a 2009. Em 2005 e 2006, foi intensificado o número de apreensões de madeira ilegal na Amazônia. Foram confiscados, em média, 202 mil metros cúbicos de madeira em cada um desses anos (Imazon, 2010). Em 2007, foram realizadas 134 operações envolvendo mais de 3 mil funcionários, incluindo Polícia Federal e Exército (Imazon, 2010 apud Ibama, 2008). Em 2008 e 2009, ocorreu a intensificação da fiscalização contra a extração ilegal de madeira no âmbito do Programa Arco de Fogo (Imazon, 2010).

No mercado nacional, São Paulo consumiu $17 \%$ da madeira processada no Bioma Amazônia em 2009, enquanto a região Nordeste consumiu 12\%, a Sudeste (excluído o estado de São Paulo) 14\%, a Sul 15\%, a Centro-Oeste 4\% e a Amazônia Legal 16\% (Imazon, 2010). No Bioma Amazônia, em 2009, foram identificados: (i) 75 polos madeireiros, que congregam 192 municípios; (ii) 2226 empresas madeireiras em funcionamento; (iii) extração de 14,2 milhões de metros cúbicos de madeira em tora nativa (equivalente a 3,5 milhões de árvores) (Imazon, 2010).

Em 2009, a zona leste do Pará consumiu em torno de 21\% da madeira em tora extraída na Amazônia; seus polos madeireiros mais significativos foram Paragominas, Tailândia, Tomé-Açú e Ulianópolis (Imazon, 2010). Em seguida, está a zona do Estuário Paraense, cujo

${ }^{11} \mathrm{O}$ IMAZON realiza estudos quantitativos em relação às atividades do setor madeireiro a cada 5 anos. Quando o presente estudo foi finalizado, o último relatório disponível havia sido publicado em 2010, trazendo dados relacionados ao ano de 2009. 
consumo atingiu aproximadamente $13 \%$ do volume de madeira (Imazon, 2010). No Estado de Mato Grosso, a atividade madeireira foi mais significativa na zona noroeste ( $12 \%$ do consumo de toras), cujos principais polos foram Colniza, Aripuanã e Juara; e na zona centro (11\%), com Sinop e Feliz Natal como os polos mais importantes (Imazon, 2010). Em Rondônia, a atividade madeireira foi mais significativa na zona norte, com $10 \%$ de todo o consumo de madeira da Amazônia; os polos madeireiros mais importantes foram Ariquemes, Porto Velho e Cujubim (Imazon, 2010).

Em relação ao número total de polos madeireiros, estes foram: 72 em 1998, 82 em 2004 e 75 em 2009 (Imazon, 2010). Nas Figuras 27-30 pode-se observar a distribuição de tais polos entre os estados da Amazônia Legal em 1997, 1998, 2004 e 2009.

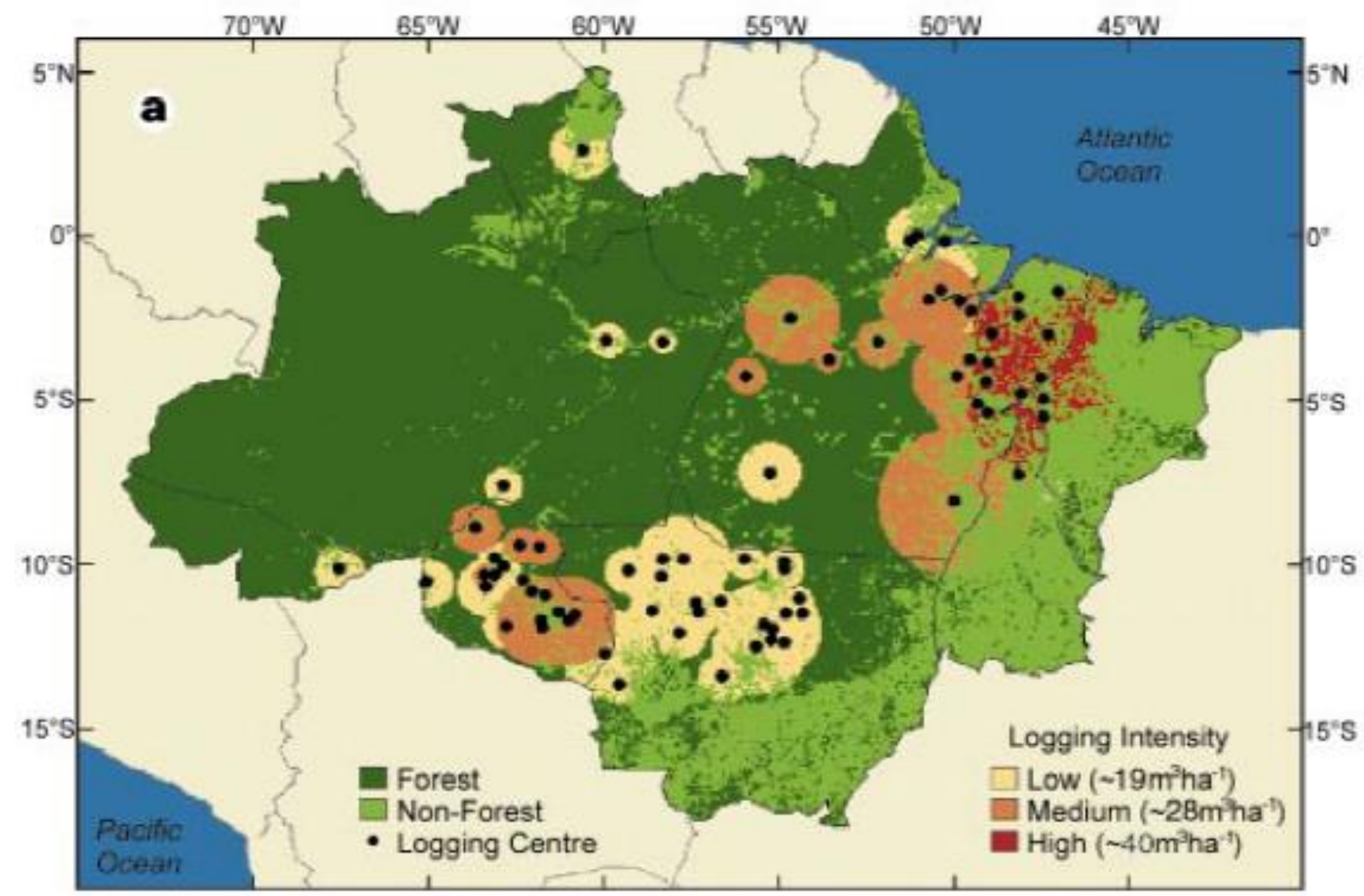

Figura 27: Zonas e polos madeireiros na Amazônia Legal em 1997. Fonte: Nepstad et al., 1999. 


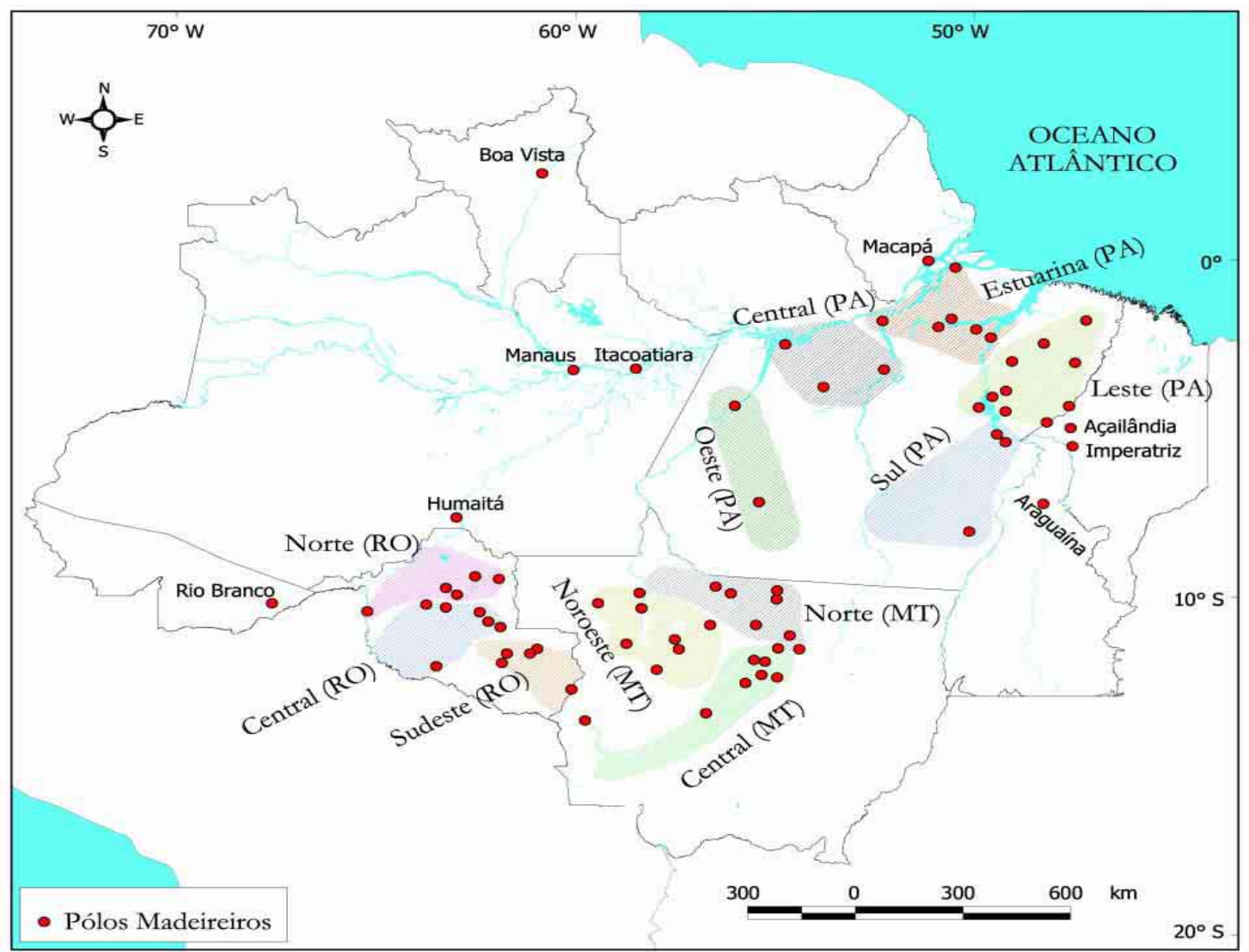

Figura 28: Zonas e polos madeireiros na Amazônia Legal em 1998. Fonte: SBF \& IMAZON, 2003.

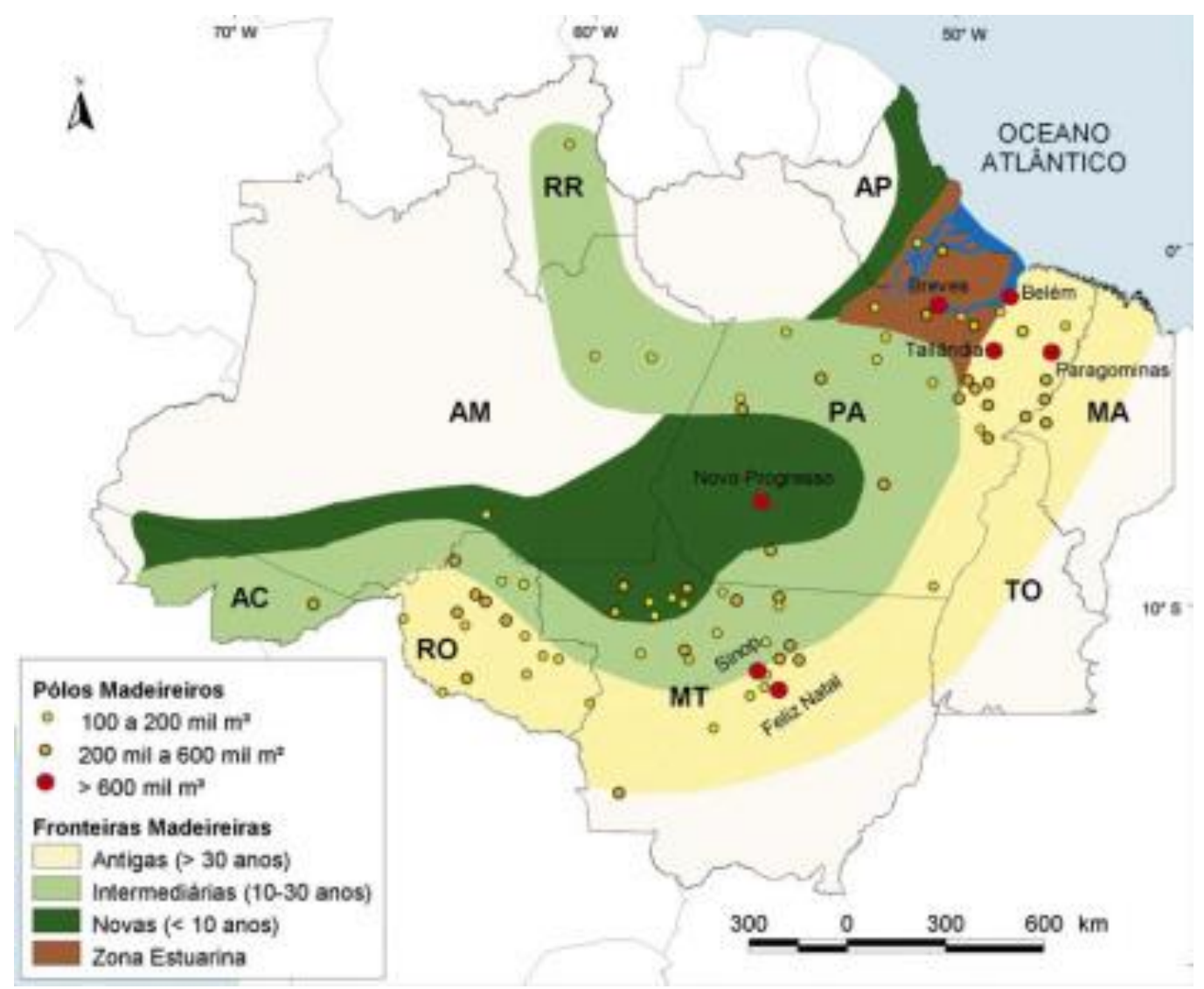

Figura 29: Zonas e polos madeireiros na Amazônia Legal em 2004. Fonte: SBF \& IMAZON, 2005. 


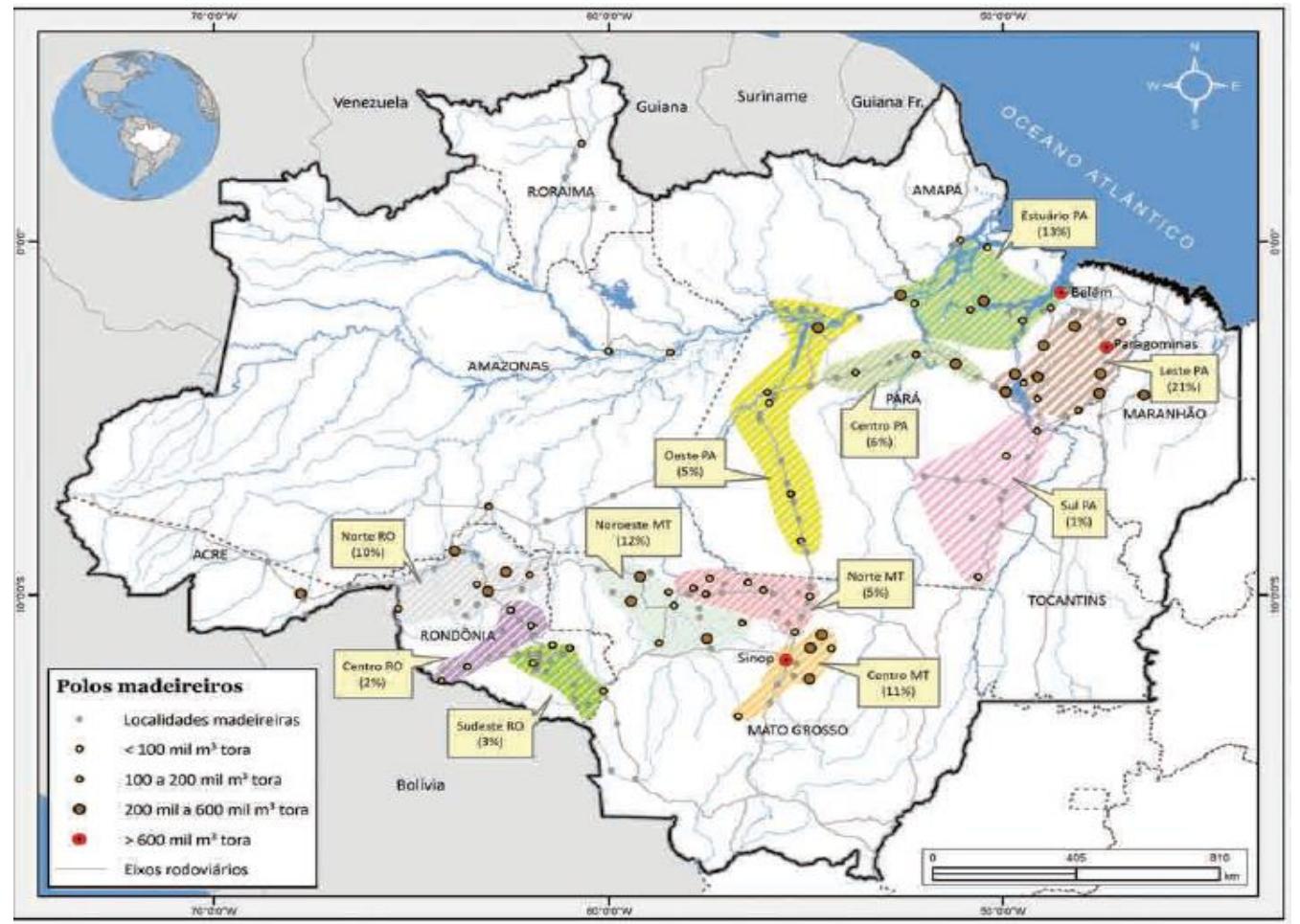

Figura 30: Zonas e polos madeireiros na Amazônia Legal em 2009. Fonte: SBF \& IMAZON, 2010

Em relação à produção anual de toras de madeira, os dados disponíveis no IBGE conflitam com aqueles fornecidos pelos estudos realizados pelo IMAZON - o que reflete a dificuldade de obtenção de dados concretos e o perfil difuso do setor. As Figuras 31 e 32 trazem tais dados (IBGE e IMAZON, respectivamente).

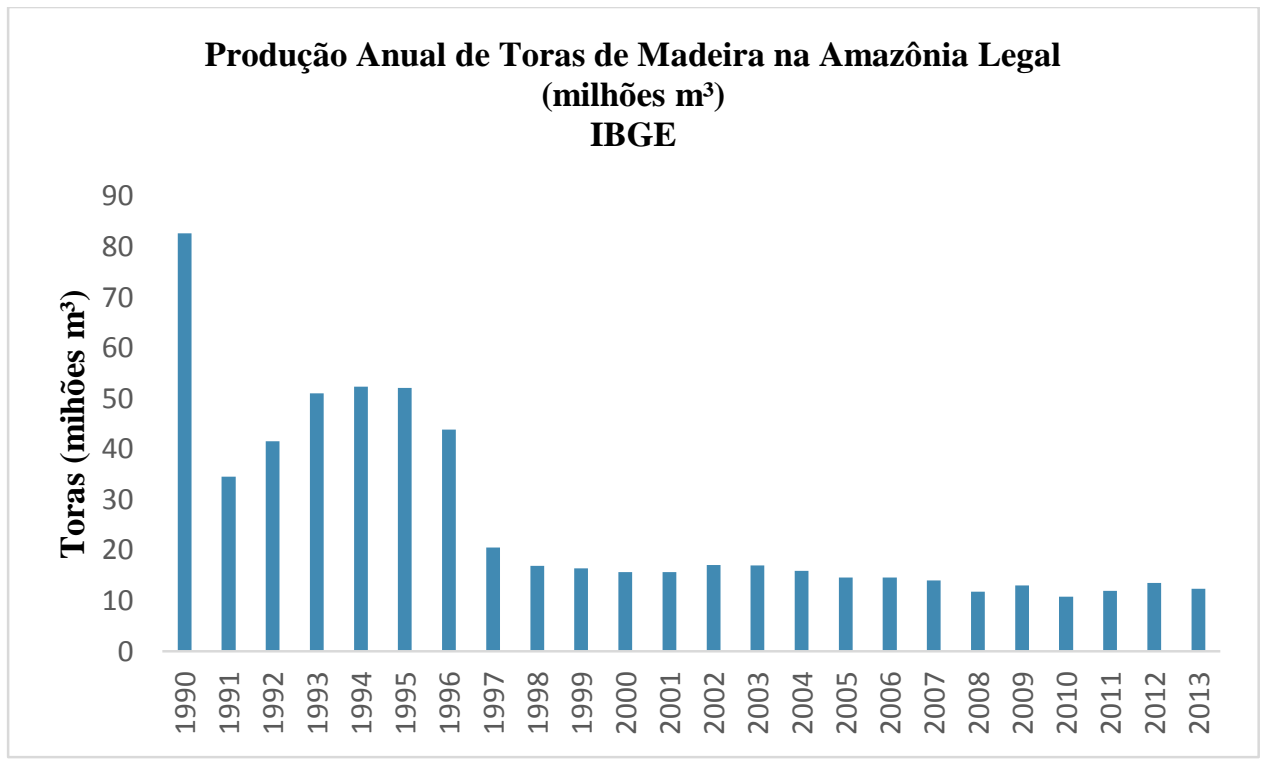

Figura 31: Produção de toras de madeira na Amazônia Legal de acordo com dados do IBGE. Fonte: IBGE, 2014. 


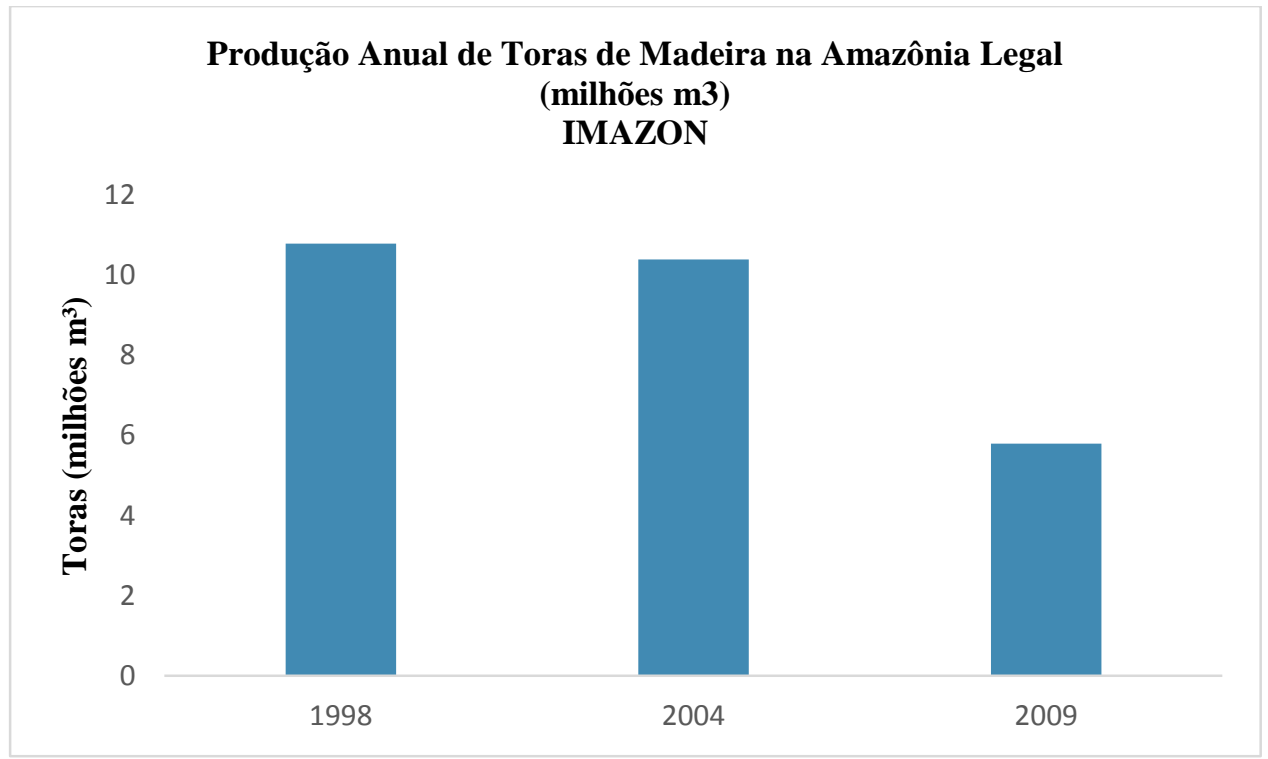

Figura 32: Produção de toras de madeira na Amazônia Legal de acordo com dados do IMAZON. Fonte: SBF \& IMAZON, 2010.

Apesar da existência de conflito entre dados gerados pelo IBGE e IMAZON, as informações acima demonstram a redução das atividades no setor madeireiro ocorrida após o ano de 2004, redução esta que tem como uma de suas possíveis causas as ações de combate à ilegalidade do setor reforçadas no período pós 2004, conforme citado anteriormente. Avanços nesse sentido podem ser observados, mas muitos problemas continuam atrelados às atividades madeireiras. Soares-Filho (2014) afirma que apesar de diversas empresas madeireiras terem sido desativadas pelo IBAMA, a ilegalidade no setor ainda é muito significativa, o que faz com que as Políticas de Concessões Florestais não sejam efetivas, já que é difícil a competição de tais políticas com práticas de exploração ilegal. Soares-Filho (2014) destaca que existem, também, dificuldades relacionadas à implementação nos Planos de Manejo Florestal, que são extremamente complexos e acarretam ônus, resultando em dificuldade de alcance de objetivos de desenvolvimento das atividades de exploração madeireira sustentável.

Valeriano (2014) destaca que, por ter ocasionado o fechamento de diversas serrarias (em Sinop, por exemplo, houve o fechamento de 520 serrarias), no ano de 2005, a operação Curupira teve grande efeito. No entanto, argumenta que graves falhas permanecem associadas ao setor madeireiro, como a falta de acompanhamento dos Planos de Manejo Florestal, devido a grandes dificuldades técnicas e ocorrência de fraudes (foram encontrados, no banco de dados do IBAMA, Planos de Manejo em locais onde não existia mais floresta (Valeriano, 2014). Valeriano (2014) argumenta que é possível afirmar que apenas no estado do Acre tal 
acompanhamento funciona de forma efetiva, devido ao comprometimento por parte do governo, que é apoiado por um grupo de geoprocessamento altamente competente.

Fearnside (2014) também afirma que a indústria madeireira continua permeada por volumosas atividades ilegais e que esse fato compromete a produção de dados confiáveis sobre o setor. Ressalta, também, que existe um grande discurso em torno da implementação de Planos de Manejo Florestal, mas que mesmo aquilo que é completamente legal em termos de burocracia dentro dos mesmos não pode ser considerado como sustentável. Os fatores econômicos relacionados à atividade continuam sendo mais importantes do que as variáveis biológicas de crescimento das florestas, onde toda a burocracia relacionada aos Planos de Manejo é direcionada à, apenas, obtenção do direito de exploração. Segundo Fearnside (2014), alguns fatores enfraquecem a legislação; a teoria do manejo florestal se dá como segue: a área a ser explorada deve ser dividida em parcelas, respeitando-se um ciclo de exploração. Em um ciclo de 30 anos, devem existir 30 parcelas e a exploração deve ocorrer em uma parcela a cada ano; no final do ciclo, volta-se a primeira parcela, onde a floresta estará teoricamente regenerada. No entanto, Fearnside (2014) ressalta que a prática é diferente: no Amazonas, por exemplo, existem projetos de 100ha destinados ao manejo florestal e que são aprovados que todos esses 100ha sejam explorados durante o primeiro ano do ciclo. Ainda segundo Fearnside (2014), deve ser considerado, ainda, que a atividade madeireira gera lucros que podem ser empregados em outras atividades que resultam em desmatamento; além disso, está associada à exploração madeireira a existência de muitos quilômetros de estradas clandestinas, que também resultam em maior desmatamento através do processo de ocupação ilegal.

Moutinho (2014) argumenta que boa parte da atividade madeireira é advinda dos processos de desmatamento, quando a madeira retirada da área desmatada tem valor econômico e é vendida. Outra parte, explicita, advém da exploração tradicional madeireira, em que há degradação, mas não há corte raso. Moutinho (2014) também destaca que ainda persiste um processo de exploração que não se dá em moldes que gerariam prosperidade econômica sustentável para a região devido a dois motivos: (i) a disponibilidade de madeira ilegal (seja ela de desmatamento ilegal ou de exploração ilegal) ainda é muito grande, e sua comercialização é corroborada pela alta ilegalidade atrelados à atividade madeireira; e (ii) o processo de concessão florestal, através das FLONAS, avançou muito lentamente, o que acabou restringindo a oferta de madeira de áreas legalizadas e monitoradas; logo, ainda há grande oferta de áreas localizadas fora de FLONAS. 
Torna-se evidente, então, a urgente necessidade de que sejam erradicados os fatores que tornam possível a expansão das atividades ilegais de exploração madeireira. Apesar da conotação negativa associada à exploração madeireira no Bioma Amazônia, há de se levar em consideração que tal atividade pode se tornar parte de uma atividade econômica sustentável mesmo nas mais remotas áreas de tal região. Merry et al. (2009) estimam haver 4,5 $\pm 1,3$ bilhões de $\mathrm{m}^{3}$ de madeira comercializável na região, que poderiam ser explorados sob planos de manejo sustentável efetivos. Fazem-se necessários, além de ações de fiscalização mais rígidas, o fornecimento de incentivos econômicos e aprimoramentos tanto em termos tecnológicos quanto profissionais para que a exploração ilegal deixe de ser prática corrente.

O Processo de Concessão Florestal deve ser aprimorado, assim como a execução e o acompanhamento dos Planos de Manejo Florestal. É fundamental que os órgãos governamentais passem a dispensar maior atenção a tais instrumentos e ao problema ocasionado pelas medidas frouxas, dispersas e ineficientes de combate à ilegalidade no setor madeireiro. Como a exploração madeireira tradicional não incorre (diretamente) no corte raso, ou seja, não incorre em aumento da taxa de desmatamento da Amazônia Legal, os esforços voltados ao aprimoramento das atividades exploratórias, de forma que se possibilite a redução de impactos ambientais, não são bem coordenados e acompanhados. No entanto, há de se considerar que a degradação florestal ocasionada pelas práticas correntes não deve ser negligenciada. As taxas de degradação na Amazônia Legal não vêm acompanhando o ritmo de redução das taxas de desmatamento na região, conforme descrito a seguir.

\subsection{ANÁliSe das TAXAS de DEgRADAÇão NA AMAZÔNIA LEGAL}

Conforme descrito no Capítulo 2, o DEGRAD é um sistema de mapeamento de áreas onde a cobertura florestal ainda não foi totalmente removida. Os dados ${ }^{12}$ fornecidos por este sistema e apresentados na Figura 33 evidenciam que as taxas de degradação florestal apresentaram picos importantes, especialmente em 2008 e 2011. Em 2012 e 2013, houve redução significativa de tal taxa, no entanto, não há segurança em relação à manutenção de baixas taxas de degradação, visto que em 2009 e 2010 também foram observadas reduções significativas, mas seguidas de um aumento substancial e preocupante de degradação florestal no ano de 2011. Ressalta-se que apenas no ano de 2013 a taxa de degradação florestal foi inferior à taxa de desmatamento anual.

\footnotetext{
12 Não há publicação de dados sobre degradação florestal anteriores ao ano de 2007.
} 


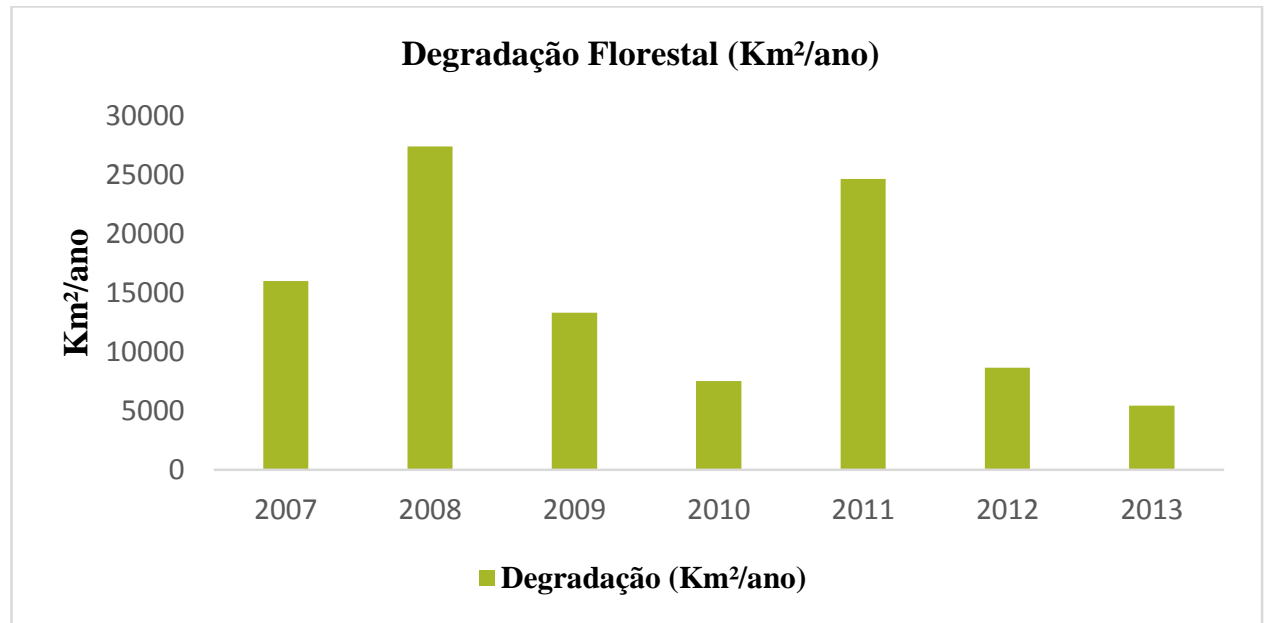

Figura 33: Taxas de degradação florestal na Amazônia Legal entre 2007 e 2013. Fonte: INPE-DEGRAD, 2014.

A Figura 34 traz a proporção de áreas degradadas em um ano convertidas a corte raso (desmatamento) no ano seguinte, entre os anos de 2007 e 2013, na Amazônia Legal.

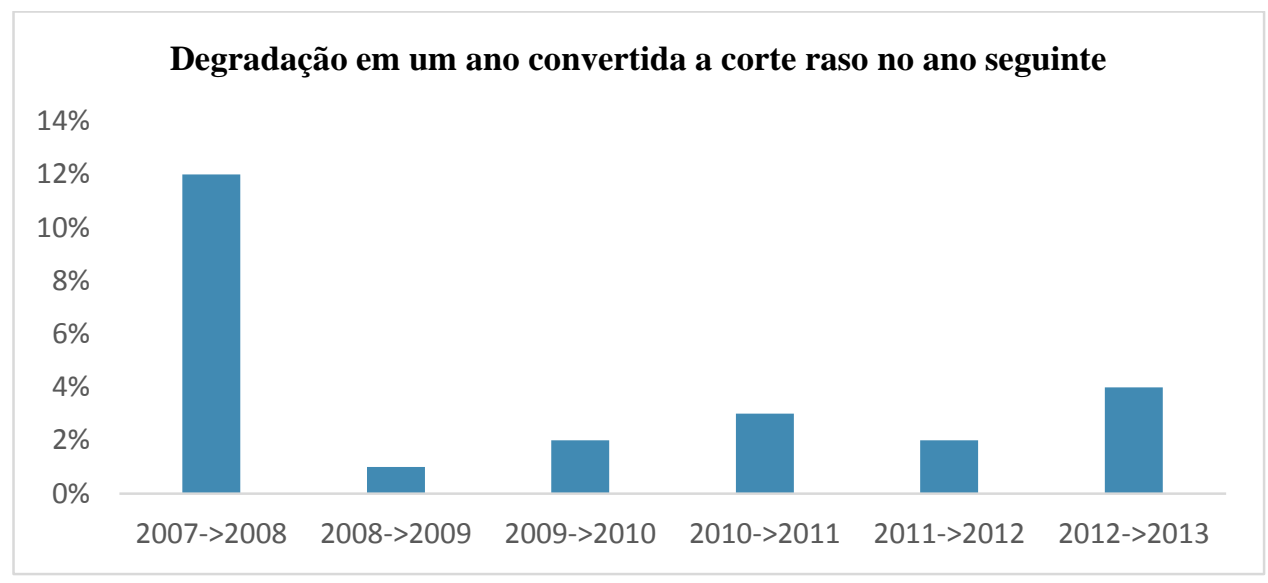

Figura 34: Áreas degradadas em um ano convertidas a corte raso (desmatamento) no ano seguinte, de 2007 a 2013. Fonte: DEGRAD-INPE, 2014.

Deve-se evidenciar que no ano de 2008 foi registrado aumento de aproximadamente $11 \%$ no desmatamento em relação a 2007 (INPE-PRODES, 2014), e há de ser levado em consideração que 12\% das áreas degradadas em 2007 foram convertidas a áreas desmatadas em 2008 (INPE-DEGRAD, 2014). Também em 2013 houve aumento de desmatamento, de aproximadamente 29\% (INPE-PRODES, 2014), e observa-se um aumento na taxa de degradação convertida em corte raso neste ano, tendo sido de 4\% (INPE-DEGRAD, 2014).

Setzer et al. (2010) demonstraram que um desmatamento ilegal de 520ha, detectado no início de 2012, em Feliz Natal - MT, foi resultado de processos de degradação e queimadas ilegais que tiveram início no ano de 2004, destacando que a área estudada sofreu maior impacto por queimadas nos anos (secos) de 2007 e 2010. O estudo evidenciou que os processos de desmatamento e seus impactos ambientais se dão de forma gradativa, e que estes 
não devem ser "considerados como representativos apenas do ano em que o desmate final foi constatado" (Setzer et al., 2010). Evidencia-se, também, que o monitoramento dos focos de queimada e de degradação florestal permitem antecipar as tendências de desmatamento ilegal com significativa antecedência, considerando que em processos dinâmicos, a extração madeireira e o uso do fogo, especialmente em anos anomalamente secos, dão início a um procedimento que dura diversos anos, até que o desmatamento final ocorra. O monitoramento através de imagens de satélite fornece os primeiros indícios a respeito da maioria das áreas que estarão sujeitas a esse tipo de dinâmica; grupos de proteção ambiental e agências de aplicação da legislação podem obter grandes benefícios fazendo uso mais efetivo de tais ferramentas (Setzer et al., 2010).

O quadro da problemática relacionada aos incêndios e degradação florestal se torna mais preocupante quando são levadas em consideração as variáveis climáticas e suas interações com as dinâmicas de uso do solo na Amazônia Legal. Conforme ilutrado abaixo, não se observou aumento de desmatamento na Amazônia Legal nos anos anomalamente secos (Figura 35) ou na estação seca ${ }^{13}$ de tais anos (Figura 36). No entanto, observa-se que os focos de incêndio florestal sofrem aumentos significativos quando da ocorrência de redução de precipitação expressiva na região (Figura 37).

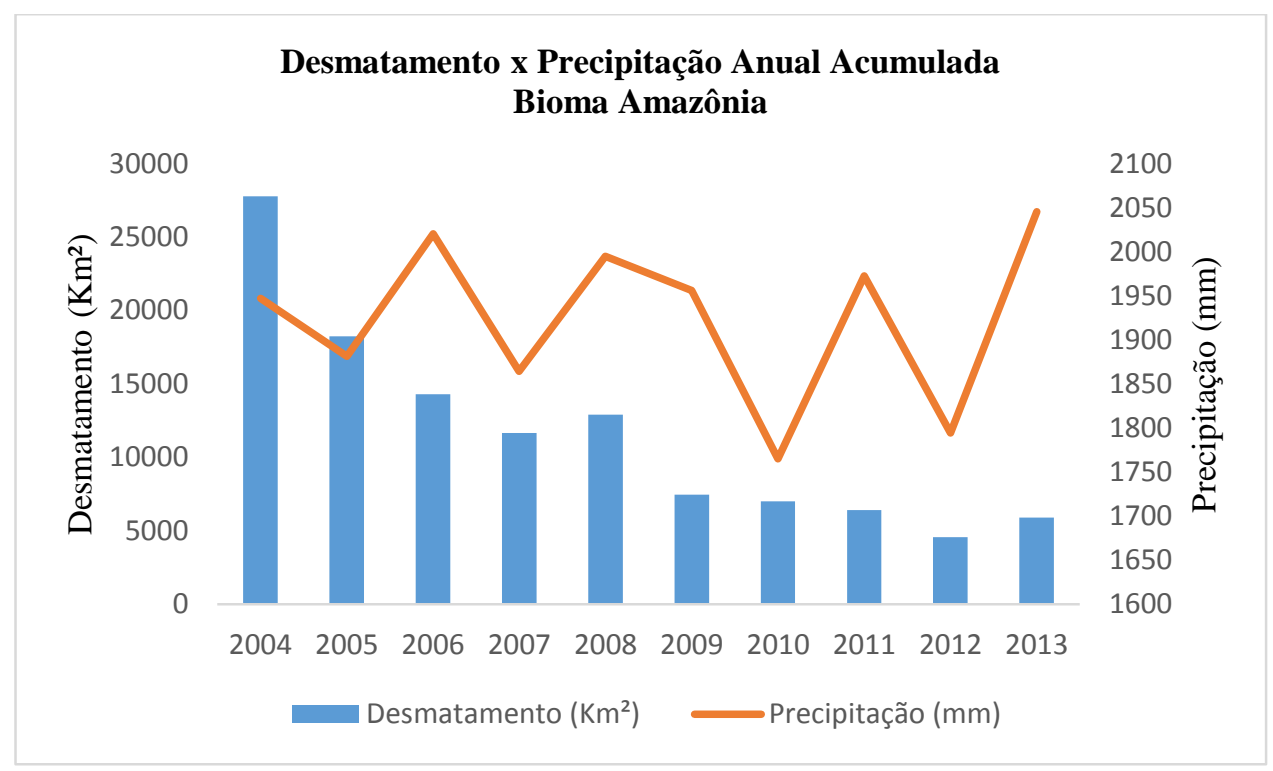
ANA, 2014.

Figura 35: Relação entre taxa de desmatamento e precipitação. Fonte: INPE, 2014; INMET, 2014;

13 Dados de precipitação compilados de junho a setembro, em todos os estados da Amazônia Legal. Dados de desmatamento compilados entre junho e setembro, de 2004 a 2013, em todos os estados da Amazônia Legal. 


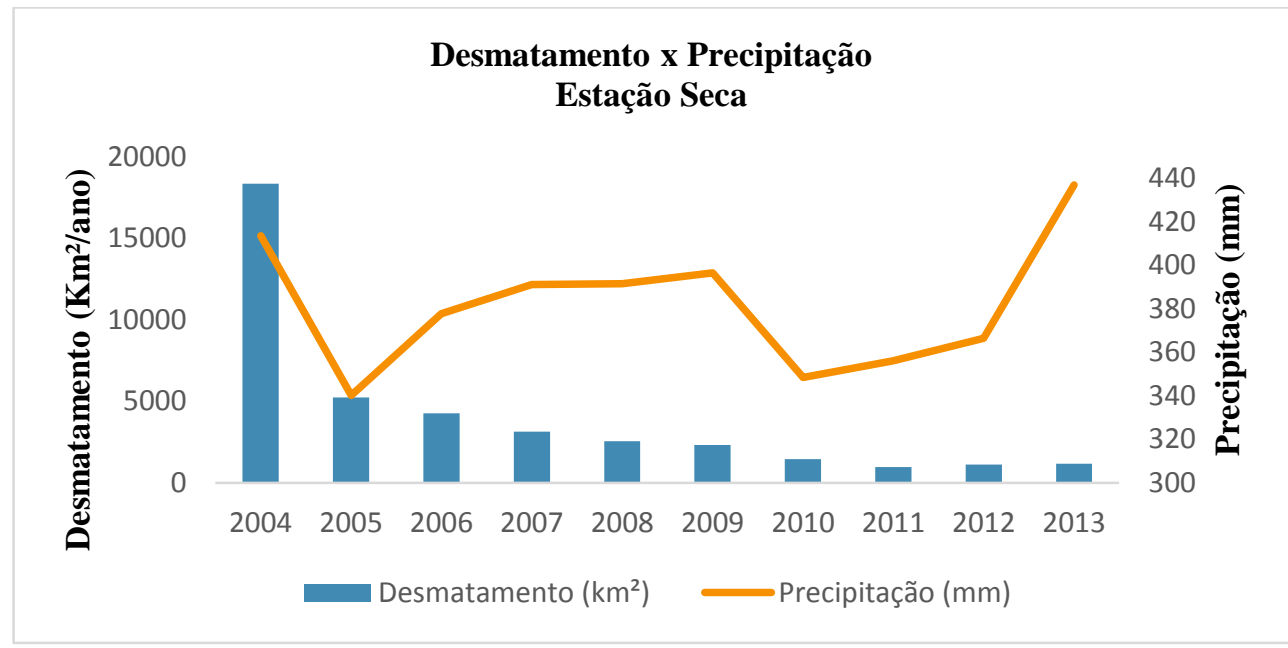

Figura 36: Relação entre taxa de desmatamento e precipitação na estação seca. Fonte: INPE, 2014; INMET, 2014; ANA, 2014.

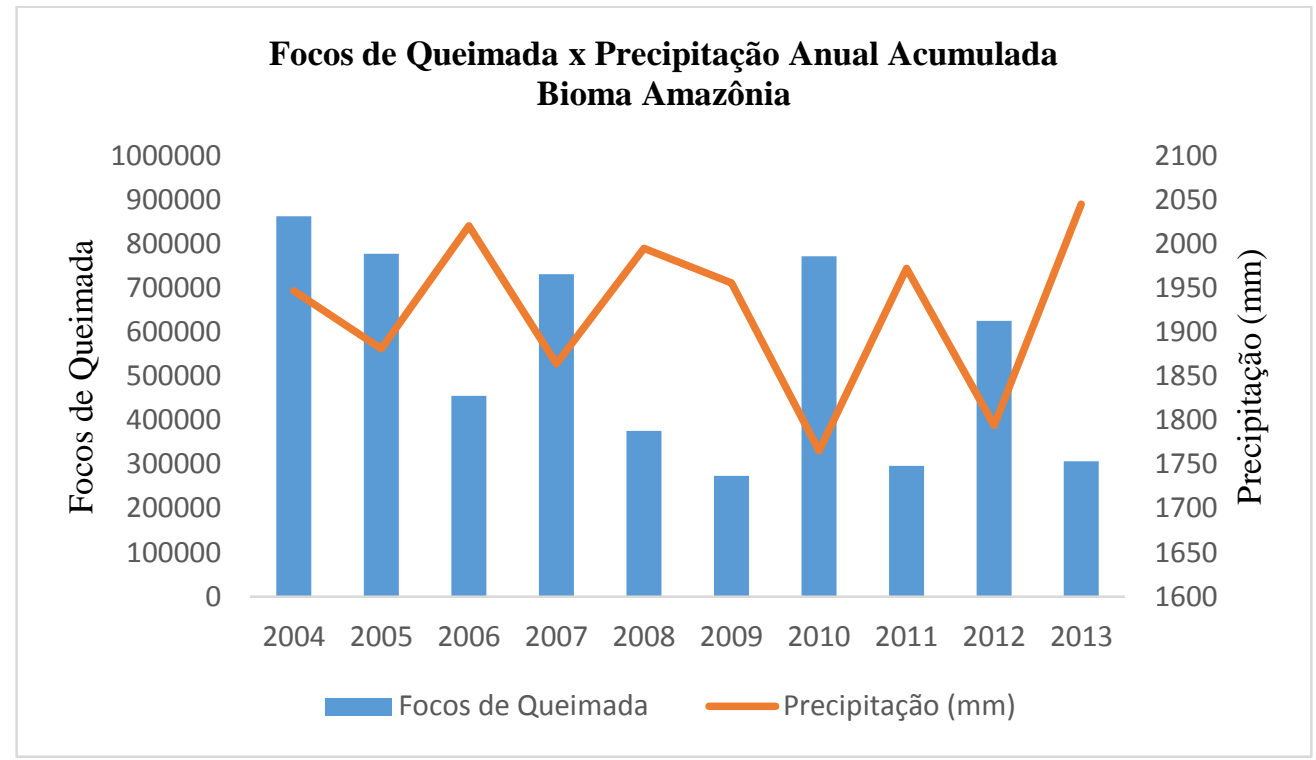

Figura 37: Relação entre número de focos de queimada e precipitação na Amazônia Legal. Fonte: INPE, 2014; INMET, 2014; ANA, 2014.

Considerando as projeções futuras de redução de precipitação na Amazônia como resultado de mudanças climáticas (ver Capítulo 1) e os impactos anteriormente citados advindos da propagação de incêndios florestais, reforça-se a necessidade de implementação de medidas de controle da degradação florestal. Mensurar a degradação florestal é um processo que impõe mais desafios em relação à mensuração das taxas de desmatamento, mas é possível que sejam aprimorados os sistemas de monitoramento que reduzam as incertezas relacionadas a tais processos (Herold et al., 2011).

Não apenas no caso do combate à degradação florestal o aprimoramento dos sistemas de monitoramento podem acarretar ganhos, isso também se aplica para o combate ao desmatamento. Novas pressões de desmatamento, como a (i) fragilidade da legislação 
ambiental; (ii) o investimento crescente em infraestrutura (rodovias, hidrovias e portos) na Amazônia Legal (obras cujas salvaguardas ambientais podem não ser fortes o suficiente para combater o desmatamento); (iii) ausência de políticas socioambientais para os assentamentos de reforma agrária na região; e (iv) demanda crescente de commodities pelo mercado externo, podem estar levando a sinergia de fatores que ocasionou a redução de desmatamento entre 2005 e 2013 a se exaurir (IPAM; IMAZON; ISA, 2013; Moutinho, 2014). Além disso, Vilela et al. (2014) alertam para o crescimento da produção de óleo de palma na Amazônia Legal, crescimento este que tende a se tornar mais expressivo uma vez que EMBRAPA identificou áreas desmatadas cujos solos e clima favorecem a plantação de tal cultura. Dessa forma, o aprimoramento dos mecanismos já existentes e a elaboração de novos mecanismos de combate ao desmatamento devem ser desenvolvidos.

Soares-Filho (2014) cita que a ciência desenvolvida em âmbito nacional vem apresentando grandes resultados no combate ao desmatamento. O diálogo entre o meio acadêmico, o governo e a sociedade civil deve ser cada vez mais fortalecido e estudos que sirvam de base para o entendimento das dinâmicas florestais na Amazônia Legal devem ser aprimorados. Sobre este ponto, deve-se destacar que estudos que reduzam as incertezas relacionadas aos estoques de carbono florestal na região são fundamentais para que seja criada uma linha de base correta para os mecanismos de REDD+. É desejável que tal mecanismo seja fortalecido em um ambiente em que diversos atores afirmaram que a necessidade da criação de instrumentos de incentivo para manutenção das florestas em pé é urgente.

É necessário que a especulação fundiária seja combatida através do estabelecimento de políticas fundiárias estáveis e eficazes, ocorrendo o comprometimento do governo e a alocação de recursos necessários à implementação das medidas necessárias (Barreto \& Silva, 2013). Também é urgente que ações que acarretem a redução a longo-prazo dos incêndios florestais na Amazônia Legal sejam implementadas. Tais ações devem emergir de investimentos e mudanças políticas que estimulem o desenvolvimento de sistemas agrícolas e de produção florestal dentro de fronteiras já existentes, e inibam a expansão de novas fronteiras. (Nepstad et al., 2001). A Amazônia Legal também carece de programas duradouros de apoio aos pequenos produtores para o cumprimento das leis ambientais, logo tais programas devem ser desenvolvidos e implementados efetivamente.

Para todos os mecanismos e instrumentos que visem o combate ao desmatamento e a degradação florestal na Amazônia Legal, é necessário levar-se em consideração que os vetores de desmatamento variam espacialmente e temporalmente na Amazônia Legal, logo, estratégias que não levem em consideração sua diversidade inter-regional - que engloba 
fatores relacionados ao clima, tipos de solo, tipos de vegetação, atividades econômicas e forças sociais e políticas - apresentarão políticas inapropriadas de desenvolvimento sustentável da região (Moran, 1993). 


\section{CONCLUSÕES}

As dinâmicas de uso do solo na Amazônia Legal são extremamente complexas, variam espacialmente e temporalmente, e são regidas por uma sinergia de diversos fatores. Embora qualitativamente seja possível elencar os fatores aos quais se pode atribuir a redução do desmatamento observada entre os anos de 2005 e 2013 na região, a análise quantitativa da influência de cada um desses requer o desenvolvimento de estudos mais aprimorados.

Não foi encontrada relação entre redução de precipitação (anos secos) e aumento de desmatamento na Amazônia Legal, o que demonstra que são os vetores econômicos, políticos e socioculturais aqueles de maior peso nas dinâmicas de desmatamento na região.

Os fatores basais para a redução do desmatamento entre os anos de 2005 e 2013 foram:

(i) A ausência de incentivos para desmatar grandes áreas devido a baixos preços de commodities de soja e carne de boi e taxas cambiais desfavoráveis entre 2005 e 2007;

(ii) A promulgação do Decreto 6321/07 e da Resolução 3545/08 do Banco Central, quando do aumento dos preços das commodities de soja e carne de boi;

(iii) A criação e expansão de áreas protegidas no âmbito do PPCDAm; e

(iv) $\mathrm{O}$ aprimoramento do monitoramento e das medidas de fiscalização na região a partir da utilização de dados gerados pelo Sistema DETER, também no âmbito do PPCDAm.

Sobre este último item, é necessário destacar que tal aprimoramento, especialmente após 2007, ocasionou a mudança comportamental por parte do agente provocador de desmatamento, que passou a ter ciência de que está sendo monitorado e passou a desmatar áreas menores a 25ha (desmatamento residual). A percepção do setor empresarial (indústrias pecuárias e agrícolas) passou a ser uma em que os riscos associados ao desmatamento (considerando-se multas agora aplicadas de forma mais efetiva e o risco de embargo de propriedades) de grandes áreas se tornaram mais caros do que os custos para sua realização Além disso, deve ser ressaltado que os dados gerados pelo Sistema DETER são polo irradiador de políticas de impacto no combate ao desmatamento (Decreto 6321/07, Resolução 3545/08 do Banco Central e criação e expansão de Áreas Protegidas).

Como fatores secundários para a redução do desmatamento pode-se citar o elemento de mercado e cultural, com a instituição das Moratórias da Soja e da Carne e o fato de os 
produtores terem começado a encontrar dificuldades para a exportação de produtos oriundos de municípios que constam na "Lista Negra" de municípios desmatadores. Tais fatores, conforme citado pelos atores entrevistados, têm efeitos que vêm se apresentando a passos lentos, mas que não podem ser desconsiderados.

Durante o período analisado de redução das taxas de desmatamento (2005 a 2013), o aumento do número de cabeças de gado na Amazônia Legal foi significantemente inferior ao observado no período entre 1980 e 2004, em termos percentuais. Análises estatísticas robustas são necessárias para confirmar uma relação de causalidade entre tal fator e a redução de áreas desmatadas. Em relação à indústria da soja, ressalta-se que, em 2008, houve aumento das áreas plantadas na região de 15,5\% em relação ao ano anterior, e em 2013, houve aumento de 17,2\%. Tanto em 2008 quanto em 2013, ocorreu aumento de desmatamento em relação ao ano anterior. Análises estatíticas robustas também se fazem necessárias para confirmar uma relação de causalidade entre tais variáveis.

É fundamental que sejam desenvolvidos novos mecanismos e aprimorados os mecanismos já existentes de combate ao desmatamento, destacando-se a necessidade da criação e implementação de maiores incentivos para manutenção da floresta em pé e do desenvolvimento de programas efetivos que envolvam o pequeno produtor da região. É fundamental, também, que seja combatida a especulação fundiária através da implementação de legislação fundiária mais rigorosa, contando-se com o comprometimento do governo e com a alocação de recursos necessária. O aprimoramento da implementação do CAR e do monitoramento das propriedades cadastradas é urgente; deve ser alcançada a homogeneidade dos efeitos positivos de tal mecanismo em todas as propriedades e toda a região.

As taxas de degradação na Amazônia Legal não vêm apresentando reduções consistentes. $\mathrm{O}$ aprimoramento das medidas de combate à ilegalidade no setor madeireiro é urgente, assim como o combate aos incêndios florestais, a longo prazo. O aprimoramento dos sistemas de monitoramento é essencial para o combate à degradação florestal e também ao desmatamento (levando-se em consideração que as práticas de desmatamento predominantes na região atualmente são aquelas em que os polígonos desmatados têm tamanho inferior a 25ha, o que torna mais difícil sua detecção pelo sistema de monitoramento em funcionamento). Ressalta-se, novamente, que o diálogo entre o meio acadêmico, o governo e a sociedade civil deve ser cada vez mais fortalecido e que os estudos que sirvam de base para o entendimento das dinâmicas florestais na Amazônia Legal devem ser aprimorados.

Embora a redução de desmatamento verificada durante o período analisado tenha sido significativa, o desmatamento anual na Amazônia Legal continua se apresentando em 
patamares altos (da ordem de $5.000 \mathrm{Km}^{2}$ em 2014), e corre-se o risco de a sinergia entre os fatores que ocasionaram tal redução estar se exaurindo devido a diversas pressões, como aumento na demanda por commodities e obras de infraestrutura como rodovias, hidrovias e portos; fragilidade da legislação ambiental; desenvolvimento de novas atividades econômicas, como produção de óleo de palma; fragilidade das salvaguardas ambientais dos projetos de desenvolvimento da região; e a ausência de políticas socioambientais voltadas aos assentamentos de reforma agrária.

Deve ser levada em consideração, ainda, a interação entre o clima e as dinâmicas florestais. Apesar do fato de que as taxas de desmatamento não apresentam aumento em anos anomalamente secos, em tais anos os focos de incêndio florestal sofrem aumentos significativos.

Logo, o desenvolvimento de novas medidas e aprimoramento daquelas já existentes para o combate ao desmatamento e degradação florestal são essenciais para que os ganhos alcançados até 2013 sejam assegurados. Tais medidas devem levar em consideração a diversidade inter-regional da Amazônia Legal, e é fundamental que estas não acarretem impactos sociais negativos, o que torna o desafio de combate à ilegalidade nas atividades econômicas desenvolvidas na região ainda mais complexo. 


\section{ANEXO I}

\section{ENTREVISTA}

\section{Dr. Alberto W. Setzer - INPE, São José dos Campos - SP, 11 de julho 2014}

1. A que fatores pode ser atribuída a redução das taxas de desmatamento na Amazônia Legal no período de 2005 a 2013? É possível distinguir que fatores exerceram maior influência?

$\mathrm{O}$ aumento/aprimoramento da fiscalização na região é a resposta para o porquê da redução do corte raso. Sem fiscalização, tal redução não teria ocorrido. Os fatores econômicos e climáticos intensificam ou reduzem esta condição.

2. Na sua visão, qual foi o impacto da Política de Combate e Controle do Desmatamento da Amazônia Legal em relação atividades econômicas desenvolvidas na região (soja, pecuária e indústria madeireira)?

O PPCDAm representa grandes evoluções do Governo Brasileiro, especialmente em relação ao fortalecimento das medidas de monitoramento e fiscalização. Mas deve-se levar em consideração a existência de uma agenda paralela à tal Política - o que explica a grande proporção de desmatamentos ilegais.

3. Segundo sua avaliação, que papel as restrições de caráter econômico (tais como restrições de crédito e restrição de acesso aos mercados) exerceram no controle do desmatamento?

Estão exercendo cada vez mais um papel expressivo. Ressalto a importância, além das restrições, dos incentivos àqueles que vem voltando esforços à redução do desmatamento e queimadas, como regalias quando da liberação de recursos.

4. Especificamente em relação à indústria madeireira, que mudanças estão correlacionadas com a diminuição do desmatamento nos estados onde esta atividade econômica é altamente expressiva?

Verifica-se ainda ilegalidade no setor. Em determinadas estradas na região, não há fiscalização, o que facilita a atividade ilegal.

É um setor muito dinâmico e difuso - acaba madeira em um local, vai-se explorar outro. 
5. As medidas de fiscalização por parte da Polícia Federal são amplamente noticiadas, como podem ser avaliadas tais medidas em termos de sua eficácia?

Força especial montada em 2013 (exército, marinha, polícia federal) - tem funcionado cada vez melhor; é realizado a nível Ministerial. 


\section{ANEXO II}

\section{ENTREVISTA}

\section{Prof. Britaldo Soares-Filho - UFMG, Belo Horizonte - MG, 21 de julho de 2014}

\section{A que fatores pode ser atribuída a redução das taxas de desmatamento na Amazônia Legal no período de 2005 a 2013? É possível distinguir que fatores exerceram maior influência?}

Primeiramente, devemos considerar que a redução da taxa de desmatamento se deu em várias fases e devido a vários fatores distintos. Ocorreu uma sinergia entre fatores. Não existe "silver bullet".

Primeiro período: 2005-2007. Houve queda da rentabilidade da agricultura (momento de crise da economia agrícola, com arrefecimento dos atores, descapitalizados na época). Ao mesmo tempo, se assiste à expansão das áreas protegidas. A nova política cria áreas protegidas em área de fronteira agrícola ativa (mudança de paradigma: anteriormente, as áreas protegidas eram criadas em locais definidos como hot spots de biodiversidade, muitas vezes áreas distantes/remotas). Com o Plano da BR-163 sustentável, houve a criação de um corredor de florestas nacionais e áreas protegidas em torno da estrada, impossibilitando a grilagem de terra. Áreas protegidas foram também criadas na Terra do Meio, Transamazônica, Estado do Amazonas, ao longo da 309 (Manaus - Porto Velho). Tal medida tirou grande área florestal do mercado especulativo de terra, tornando inviável a grilagem de terra. Verifica-se, ainda nesse período, o aumento da fiscalização e comando-e-controle com os Planos do PPCDAm. Com o mesmo, houve aumento das campanhas de campo, as forças-tarefas de fiscalização e punição. Também se destaca o papel de atuação do Estado, liderada pela Marina Silva e Capobianco. Não deve ser esquecido o aporte financeiro internacional.

Segundo Período: Pós 2008. Os principais elemento de combate ao desmatamento foram a criação da "lista negra" de munícipios prioritários e a restrição ao crédito rural política chave. Verifica-se claro aumento do desempenho ambiental dos municípios listados como "negros".

Deve-se ressaltar, também, que os 20 anos de ativismo das ONGs, especialmente as nacionais (como IMAZON e IPAM), tendo o subsídio da ciência desenvolvida em âmbito nacional, tem grande papel na promoção de debates com as políticas públicas. Além disso, deve-se destacar o grande papel da ciência em influenciar as políticas públicas. 
Todas as ações geraram uma ciência, não exatamente uma consciência ambiental, de que o desmatamento é um péssimo negócio para os produtores; fazendeiros vem sendo “aterrorizados" pelo IBAMA e é crescente a preocupação com a ilegalidade e todo o fardo que isso pode acarretar às atividades econômicas.

2. Na sua visão, qual foi o impacto da Política de Combate e Controle do Desmatamento da Amazônia Legal em relação atividades econômicas desenvolvidas na região (soja, pecuária e indústria madeireira)?

A ação do comando-e-controle tem limitações; serve para criar um choque, mas posteriormente é necessário que haja uma política de adequação em nível municipal.

3. Segundo sua avaliação, que papel as restrições de caráter econômico (tais como restrições de crédito e restrição de acesso aos mercados) exerceram no controle do desmatamento?

Embargos/Moratória da Soja e Carne: o papel não é tão claro, ainda não foi claramente comprovado. Análises mais robustas são necessárias para identificar se isso está acontecendo ou não.

Papel maior das Moratórias: pressões sobre os maiores atores ligados às cadeias produtivas da soja e carne. Essa pressão ainda está no início, os atores se mexem muito devagar e fazem o mínimo.

Restrição de crédito: política limitada pois ao mesmo tempo que são criadas as restrições, ofertas devem ser criadas. Deve-se trabalhar com os produtores rurais para ajudalos a atingir critérios ambientais, receberem certificação, e etc.

4. Especificamente em relação à indústria madeireira, que mudanças estão correlacionadas com a diminuição do desmatamento nos estados onde esta atividade econômica é altamente expressiva?

Várias empresas madeireiras foram desativadas pelo IBAMA e passa-se de uma produção de 24 milhões de metros cúbicos para 14 milhões.

Políticas de Concessões florestais não deslancharam pois é difícil competir com a atividade ilegal, que ainda é presente. Fazem parte de um processo moroso; apenas 2 estão começando a entrar em operação.

Planos de manejo são extremamente complexos e acarretam um ônus. 
5. As medidas de fiscalização por parte da Polícia Federal são amplamente noticiadas, como podem ser avaliadas tais medidas em termos de sua eficácia?

A articulação a nível federal foi muito mais eficaz. Na maioria dos estados, se tem uma estrutura sucateada, a corrupção permeia mais facilmente, sistemas não transparentes: impactam a eficácia da medida. 


\section{ANEXO III}

\section{ENTREVISTA}

Dalton Valeriano - INPE, São José dos Campos - SP, 3 de julho de 2014

1. A que fatores pode ser atribuída a redução das taxas de desmatamento na Amazônia Legal no período de 2005 a 2013? É possível distinguir que fatores exerceram maior influência?

O PPCDAm é o motor propulsor da redução de desmatamento.

2. Na sua visão, qual foi o impacto da Política de Combate e Controle do Desmatamento da Amazônia Legal em relação atividades econômicas desenvolvidas na região (soja, pecuária e indústria madeireira)?

Com o PPCDAm, o monitoramento e a fiscalização da Amazônia Legal foram aprimorados, o que resultou na redução das taxas de desmatamento na região.

3. Segundo sua avaliação, que papel as restrições de caráter econômico (tais como restrições de crédito e restrição de acesso aos mercados) exerceram no controle do desmatamento?

Tem papel claro em influenciar mudanças de comportamento. Pode-se afirmar que o mercado vem exercendo maior pressão para garantir que seus produtos não sejam oriundos de áreas onde houve desmatamento, mas muitos avanços ainda se fazem necessários. A restrição de crédito rural obriga o agente desmatador a ser mais cauteloso, caso não haja outra fonte de financiamento para suas atividades.

4. Especificamente em relação à indústria madeireira, que mudanças estão correlacionadas com a diminuição do desmatamento nos estados onde esta atividade econômica é altamente expressiva?

Apesar de diversas ações que resultaram no fechamento de vários polos madeireiros, esse continua a ser um setor amplamente afetado pela ilegalidade e corrupção.

5. As medidas de fiscalização por parte da Polícia Federal são amplamente noticiadas, como podem ser avaliadas tais medidas em termos de sua eficácia?

Se tornaram mais eficazes após a implementação do Sistema DETER, e seu desempenho foi chave para a redução de desmatamento observada. 


\section{ANEXO IV}

\section{ENTREVISTA}

\section{Paulo Moutinho - IPAM, 14 de julho de 2014 (Entrevista via Skype)}

\section{A que fatores pode ser atribuída a redução das taxas de desmatamento na Amazônia Legal no período de 2005 a 2013? É possível distinguir que fatores exerceram maior influência?}

É difícil quantificar a proporção da redução da taxa de desmatamento que se pode aferir a cada fator que influenciou nessa redução. Essa é uma resposta muito mais qualitativa do que quantitativa, embora, dependendo do período, seja mais fácil indicar quantitativamente que medidas tiveram maior efeito sobre a redução do desmatamento. Divido minha resposta em períodos de tempo entre 2005 e 2013.

Período I - 2005 a 2007

3 fatores fundamentais: (i) a criação de quase 25 milhões de hectares de áreas protegidas na Amazônia; (ii) forte ação de fiscalização e de campanhas do Governo Federal através do IBAMA e da Polícia Federal, que tiveram efeitos, principalmente efeitos regionalizados, bastante efetivos na derrubada da taxa e (iii) o preço das commodities no mercado internacional.

Período II - Após 2008

Principal: em 2008, a Lista Negra de Municípios e Restrição de Crédito Rural

Outros fatores que vêm reforçar a queda de desmatamento associada à restrição de crédito rural: 2009 - Moratória da Soja (Difícil quantificar, mas teve um rebate indireto sobre o desmatamento).

Nos últimos 2 anos, o desmatamento verificado é o que vem sendo chamado de desmatamento residual, embora ainda sejam grandes áreas desmatadas, que é muito ligado a assentamentos rurais/da reforma agrária e à exploração de florestas e desmatamento em terras públicas. Aumento de 2013: quase 60\% ocorreu em Terra Pública, ou seja, o médio e grande produtor deixam de ser o grande veículo propulsor de desmatamento durante os últimos 2 anos, e sim a grilagem e o desmatamento em volta de áreas protegidas (assim como desmatamentos em assentamentos). 
2. Na sua visão, qual foi o impacto da Política de Combate e Controle do Desmatamento da Amazônia Legal em relação atividades econômicas desenvolvidas na região (soja, pecuária e indústria madeireira)?

Traz para discussão regionalização do problema, gerando um processo de aumento de discussão no âmbito governamental amazônico. Também traz uma discussão, além do eixo de comando-e-controle, que já se encontra em seu limite, a questão do fomento e incentivos a atividades ou comportamentos sustentáveis em relação à floresta. Também tem um papel importante na questão do monitoramento, especialmente o entendimento através dos dados do PRODES a respeito dos fatores regionalizados de avanço do desmatamento.

Porém, é um programa com muitas falhas de implementação. Também existem falhas em relação à avaliação do impacto que essa política realmente teve de uma maneira clara e objetiva. O Programa não teve, necessariamente, efeitos diretos nas taxas (o que é outra coisa difícil de ser determinada) mas abriu uma discussão no âmbito governamental Amazônico importante.

3. Segundo sua avaliação, que papel as restrições de caráter econômico (tais como restrições de crédito e restrição de acesso aos mercados) exerceram no controle do desmatamento?

Ver 1 questão

4. Especificamente em relação à indústria madeireira, que mudanças estão correlacionadas com a diminuição do desmatamento nos estados onde esta atividade econômica é altamente expressiva?

Boa parte da atividade madeireira é advinda dos processos de desmatamento (entra-se em uma área, desmata-se essa área, árvores retiradas têm valor econômico e madeira é vendida). Outra parte vem da exploração tradicional em que há degradação, mas não há corte raso. Ainda persiste um processo de exploração que não se dá em moldes que gerariam prosperidade econômica sustentável para a região por 2 motivos: disponibilidade de madeira ilegal (seja ela de desmatamento ilegal ou de exploração ilegal) ainda é muito grande; e, todos os esforços que o governo fez, por mais nobres que tenham sido, na questão de concessão florestal, esta teve uma limitação muito grande (FLONAS), esse processo avançou muito lentamente, o que acabou restringindo a oferta de madeira de áreas legalizadas e monitoradas. E ainda há grande oferta, mesmo de madeira legal, de áreas localizadas fora das FLONAS. Em termos de PP, que pudessem amarrar a redução 
do desmatamento à exploração sustentável de madeira, especialmente através das concessões florestais e manejo sustentável, essas não existiram, não há uma ligação clara. A exploração madeireira financia o desmatamento. A corrupção nessa área é muito alta.

\section{As medidas de fiscalização por parte da Polícia Federal são amplamente noticiadas, como podem ser avaliadas tais medidas em termos de sua eficácia?}

A fiscalização será sempre importante, desde que seja bem planejada e de forma estratégica, mas esta é muito mais emergencial do que de prevenção. E chegou num limite, que para avançar, necessita de reformulação de estrutura e procedimentos, principalmente nos Estados e Municípios. Com a descentralização da gestão ambiental, passou-se do Federal para os Estados, e em casos dos Estados para os Municípios, a responsabilidade em relação à gestão ambiental sem que houvesse um repasse de recursos ou capacitação técnica, o que traz um problema sério às medidas de fiscalização. $O$ PPCDAm não fez o planejamento da intervenção da fiscalização de forma adequada, a fiscalização emergencial já não é mais efetiva. A fiscalização deixou de ser efetiva a partir da descentralização. 


\section{ANEXO V}

\section{ENTREVISTA}

\section{Dr. Philip Fearnside - INPA, Manaus - AM, 27 de junho de 2014.}

\section{A que fatores pode ser atribuída a redução das taxas de desmatamento na Amazônia Legal no período de 2005 a 2013? É possível distinguir que fatores exerceram maior influência?}

Há a distinção entre duas fases. Na primeira fase, entre 2005 e 2007, a redução do desmatamento está associada à diminuição dos preços das commodities de soja e carne de boi e, também, às taxas cambiais (real/dólar) que sofreram reduções no período citado, em que ocorreu mais da metade da redução das taxas de desmatamento na região. Na fase seguinte, de 2008 em diante, os preços das commodities se recuperaram e o fator mais evidente para a manutenção do declínio das taxas de desmatamento foi a Resolução 3545 do Banco Central que restringe o crédito agrícola às atividades produtivas associadas a desmatamento ilegal. A eficácia dessa medida é evidente, já que o acesso ao crédito é imediatamente suspenso quando detectadas irregularidades, sendo muito mais eficiente do que a aplicação de multas, já que não se pode recorrer a recursos para a suspensão da penalidade. A restrição de crédito constitui, então, o fator que explica a manutenção da redução de desmatamento mesmo quando os preços das commodities se eleva. Deve-se ressaltar que esta é uma proteção muito frágil, já que a Resolução pode ser modificada a qualquer momento.

2. Na sua visão, qual foi o impacto da Política de Combate e Controle do Desmatamento da Amazônia Legal em relação atividades econômicas desenvolvidas na região (soja, pecuária e indústria madeireira)?

O programa governamental é uma boa e necessária iniciativa, mas corre-se o risco de interpretação de que, devido à existência do mesmo, a situação se encontra sob controle. A criação de áreas protegidas teve impactos positivos e tem grande importância, inclusive a longo prazo (é uma medida mais permanente do que, por exemplo, as Moratórias da Soja e da Carne), mas deve-se ressaltar que justamente no ano de 2008, houve a paralização da criação de novas Unidades de Conservação no estado do Amazonas, que era um dos campeões na criação de Unidades de Conservação Estaduais até março de 2008 e há movimentos (PEC 215) que dificultam a criação de novas Áreas de Conservação em nível Federal. 
3. Segundo sua avaliação, que papel as restrições de caráter econômico (tais como restrições de crédito e restrição de acesso aos mercados) exerceram no controle do desmatamento?

Acordos com Sojeiros (e moratórias) não explicam a redução ocorrida em 2008, e sim a restrição de crédito.

4. Especificamente em relação à indústria madeireira, que mudanças estão correlacionadas com a diminuição do desmatamento nos estados onde esta atividade econômica é altamente expressiva?

Deve-se ressaltar que a indústria madeireira continua permeada por volumosas atividades ilegais, o que compromete a produção de dados sobre o setor. Existe um grande discurso em torno da implementação de planos de manejo florestal, porém mesmo o que é completamente legal, em termos de burocracia, dentro dos planos de manejo não pode ser considerado sustentável. Os fatores econômicos relacionados à atividade continuam sendo mais importantes do que as variáveis biológicas de crescimento das florestas. Toda a burocracia relacionada aos planos de manejo é direcionada à, apenas, obtenção do direito de exploração. Houve uma explosão de implementação de planos de manejo. No Acre, há uma grande quantidade de planos e grandes volumes de extração madeireira. Alguns fatores enfraquecem a legislação; a teoria do manejo florestal é que a área a ser explorada seja dividida em parcelas, por exemplo em um ciclo de 30 anos, em 30 parcelas, então a exploração deve correr em uma parcela a cada ano e, no final do ciclo, volta-se a primeira parcela, onde a floresta estará regenerada. No entanto, a prática é diferente. No Amazonas, existem projetos de 100 ha destinados ao manejo florestal e se aprova que esses 100 ha sejam explorados no primeiro ano, o que significa que, teoricamente, a empresa deveria esperar 29 anos para retomar as atividades de exploração, o que é muito improvável que aconteça. Deve ser considerado, ainda, que a atividade madeireira gera lucros que podem ser empregados em outras atividades que resultam em desmatamento. Além disso, está associada à exploração madeireira a existência de muitos quilômetros de estradas clandestinas, que também resultam em maior desmatamento.

5. As medidas de fiscalização por parte da Polícia Federal são amplamente noticiadas, como podem ser avaliadas tais medidas em termos de sua eficácia? 
São medidas importantes, não se pode dizer que não vale a pena investir em fiscalização. É fundamental que essas ações sejam visíveis e divulgadas, no sentido de que se torne claro que a violação de regras acarreta consequências. Existem, porém, limitações relacionadas a tais ações. Por exemplo, no Pará, existiu um período em que ordens eram dadas aos agentes de fiscalização para que estes "não fizessem nada caso os grileiros reagissem". 


\section{ANEXO VI}

\section{ENTREVISTA}

\section{Raoni Rajão - UFMG, Belo Horizonte - MG, 21 de julho de 2014}

\section{A que fatores pode ser atribuída a redução das taxas de desmatamento na Amazônia Legal no período de 2005 a 2013? É possível distinguir que fatores exerceram maior influência?}

O esclarecimento do ponto de vista científico é muito difícil: historicamente, se podia explicar as dinâmicas de desmatamento a partir de modelos econométricos; o desmatamento era ligado a decisões de investimento (expansão de lavouras, expansão de atividades pecuárias), fatores macroeconômicos explicavam as dinâmicas. A partir de 2008, houve um descolamento disso, por uma série de motivos. A partir de então, modelos econométricos não são mais suficientes para explicar a dinâmica de desmatamento na região, pois tais modelos partem de um princípio de uma realidade sem Estado/ sem Instituições. Mas a partir do momento em que houve o descolamento citado acima, há a influência das Instituições, que podem ser entendidas de maneira bastante ampla: desde Instituições Sociais, mudanças culturais (forma como os agropecuaristas passaram a enxergar as leis e novas exigências de mercado) e presença do Estado. É particularmente complicado modelar esses itens - um pouco da dificuldade científica reside nessa questão.

Início do Governo Lula: Primeiro, início da gestão de Marina Silva: primeira ministra do meio ambiente com força política, compromisso e ressonância de sua voz perante à Presidência.

Liga entre debate político, conceitual e o chão: DETER, não somente pela geração de dados em tempo real, mas pois a criação desse sistema se deu juntamente com uma nova geração de fiscais do IBAMA, que tinham conhecimento de como trabalhar com Sistemas de Informação Geográfica, com um contato direto com o INPE e o uso dos dados para planejar suas ações de campo, o que gerou um entendimento, por parte dos proprietários de terra, de que agora há vigilância/fiscalização efetiva -> mudança comportamental e fragmentação do desmatamento (desmatamento agora é feito em parcelas menores, em um tempo maior). Até então, o maior entrave ao desmatamento de grandes áreas era o custo disso. 
Pressão externa - guinada verde no setor de compras em mercados importantes (embora mercados como a China não tenham tal preocupação). 2007/2008: produtores começaram a encontrar problemas pois sua mercadoria não estava sendo aceita no mercado externo devido ao fato de seu município estar na Lista Negra de municípios desmatadores - resistência dos produtores perdeu força.

Elemento Político (Marina Silva tendo conseguido elevar o status dessa agenda), Elemento Tecnológico (que possibilitou a ligação entre os vários mundos/realidades) e Elemento Econômico, de mercado.

Monitoramento: Tecnologia estabelecida que fornece dados - gera-se informação e o desmatamento torna-se realidade constituída, algo concreto que tem tangência política. 


\author{
ANEXO VII \\ ENTREVISTA \\ Tasso Azevedo, São Paulo - SP, 22 de julho de 2014
}

1. A que fatores pode ser atribuída a redução das taxas de desmatamento na Amazônia Legal no período de 2005 a 2013? É possível distinguir que fatores exerceram maior influência?

Cinco principais elementos explicam a redução da taxa de desmatamento: (i) a implementação do PPCDAm, que gerou a ação orquestrada de combate ao desmatamento; (ii) as variações de condições econômicas de produção rural (não associadas a preços dos produtos, mas a condições relacionadas à infraestrutura e ao clima, que têm grande impacto na produção rural); (iii) a implementação de mecanismos de desincentivo econômico ao desmatamento, como a restrição de crédito rural; (iv) a expansão e criação de áreas protegidas; e (v) o aprimoramento do monitoramento da região. 


\section{REFERÊNCIAS}

Abdala, G. Plano de Ação para Prevenção e Controle do desmatamento na Amazônia Legal (PPCDAM) Documento de avaliação 2004-2007. Brasília, DF: Ministério do Meio Ambiente, 2008.

Agência Nacional de Águas. Informações Hidrológicas. Disponível em: < http://www2.ana.gov.br/Paginas/servicos/informacoeshidrologicas/redehidro.aspx $>$. Acesso em 23 de outubro de 2014.

Aguiar, A. P. D.; Câmara, G. E.; Sobral, M. I. Spatial statistical analysis of land-use determinants in the Brazilian Amazonia: Exploring intra-regional heterogeneity. Ecological Modelling, v. 209, n. 2-4, p. 169-188, 2007.

Aguiar, A.P.D.; Ometto, J.P.; Nobre, C.; Lapola, D.M.; Almeida, C.; Vieira, I. C.; Soares, J.V. Alvala, R.; Saatchi, S.; Valeriano, D.; Castilla-Rubio, J.C. Modeling the spatial and temporal heterogenity of deforestation-driven carbon emissions: the INPE-EM framework applied to the Brazilian Amazon. Global Change Biology. v. 18, n. 11. p. 3346-3366, 2012.

Alves D. S.; Morton D. C.; Batistella M.; Roberts D. A.; Souza C. The Changing Rates and Patterns of Deforestation and Land Use in Brazilian Amazonia in Amazonia and Global Change, Geophys. Monogr. Ser., v. 186, 565 pp., AGU, Washington, D. C., 2007.

Andersen, L. E. The dynamics of deforestation and economic growth in the Brazilian Amazon. Cambridge: Press Syndicate of the University of Cambridge, 2002.

Andreae, M.O.; Almeida, S. S. de; Artaxo, P.; Brandão, C.; Carswell, F. E.; Ciccioli, P.; Culf, A.; Esteves, J. L.; Gash, J.; Grace, J.; Kabat, P.; Lelieveld, J.; Malhi, Y.; Manzi, A. O.; Meixner, F. X.; Nobre, A.; Nobre, C.; Ruivo, M. A. de L.; Silva-Dias, M. A. F.; Stefani, P.; Valentini, R.; Jouanne, J. von; Waterloo, M. Biogeochemical cycling of carbon, water, energy, trace gases and aerosols in Amazonia: The LBA-EUSTACH experiments. Journal of Geophysical Research , v. 107, D20, p. 8.066-8.091, 2002.

Araujo, C.; Bonjean, C. A. C. ; Combes J. L. ; Motel, P. C. ; Reis, E. J. Property rights and deforestation in the Brazilian Amazon. Ecological Economics, v. 68, n. 8-9, p. 2461-2468, 2009.

Arco, E. Dinâmica socioeconômica e desmatamento na Amazônia. Novos Cadernos NAEA v. 8, n. 2, p. 5-39, 2005.

Arima, E. Y.,; Barreto, P.; Araújo, E.; Soares-Filho, B. Public policies can reduce tropical deforestation: Lessons and challenges from Brazil. Land Use Policy, v. 41, p. 465-473, 2014.

Artaxo, P., Desmatamento, meio ambiente e desenvolvimento sustentável na Amazônia. Revista Médica da Faculdade de Medicina da USP. Ano I, 2, p. 110-114, 1998.

Artaxo, P., Martins, J. V. , Yamasoe, M. A., Procópio, A. S., Pauliquevis, T. M., Andreae, P., Guyon, L. V. Gatti, A. M. C. Leal. Physical and chemical properties of aerosols in the wet and 
dry season in Rondônia, Amazonia. Journal of Geophysical Research, v. 107, n. D20, p. 8081 $-8095,2002$.

Artaxo, P., Pauliquevis, T. M., Lara, L. L. Dry and wet deposition in Amazonia: from natural biogenic aerosols to biomass burning impacts. International Global Atmospheric Chemistry Project - IGAC Newsletter, no. 27, pg. 12-16, Janeiro 2003.

Artaxo, P.; Gatti, L. V.; Leal, A. M. C.; Longo, K. M.; Freitas, S. R. D.; Lara, L. L.; Pauliquevis, T. M.; Procópio, A. S.; Rizzo, L. V. Química atmosférica na Amazônia: a floresta e as emissões de queimadas controlando a composição da atmosfera amazônica. Acta Amazonica, v. 35, n. 2, p. 185-196, 2005.

Assunção, J.; Gandour, C.; Rocha, R. Does Credit Affect Deforestation? Evidence from a Rural Credit Policy in the Brazilian Amazon. Núcleo de Avaliação de Políticas Climáticas da Pontifícia Universidade Católica do Rio de Janeiro (NAPC/PUC-Rio) \& Climate Policy Initiative Rio de Janeiro (CPI Rio), 2013a.

Assunção, J.; Gandour, C.; Rocha, R. DETERring Deforestation in the Brazilian Amazon: Environmental Monitoring and Law Enforcement. Núcleo de Avaliação de Políticas Climáticas da Pontifícia Universidade Católica do Rio de Janeiro (NAPC/PUC-Rio) \& Climate Policy Initiative Rio de Janeiro (CPI Rio), 2013b.

Azevedo, T. Fatores Responsáveis pela Redução de Desmatamento na Amazônia Legal entre 2005 e 2013 [Julho de 2014]. Entrevista Concedida a Natália Mello.

Azevedo, A. A.; Rajão, R. L.; Costa, M.; Stabile, M. C. C.; Alencar, A.; Moutinho, P. Cadastro Ambiental Rural e sua influência na dinâmica do desmatamento na Amazônia Legal. Boletim Amazônia em Pauta. IPAM, 2014.

Azevedo-Ramos, C., Silva, J. N., Merry, F. The evolution of Brazilian forest concessions. Elementa Journal. Disponível em: < https://elementascience.org/articles/48 >. Acesso em: 27 de agosto de 2015.

Banco Central do Brasil. Resolução 3.545, de 29 de fevereiro de 2008. Altera o MCR 2-1 para estabelecer exigência de documentação comprobatória de regularidade ambiental e outras condicionantes, para fins de financiamento agropecuário no Bioma Amazônia. Disponível em: $<$ http://www.bcb.gov.br/pre/normativos/busca/normativo.asp?tipo=Res\&ano=2008\&numero= 3545> Acesso em 05 de maio de 2013.

Banco Central do Brasil. Taxas de Câmbio. Disponível em: < http://www4.bcb.gov.br/pec/taxas/port/ptaxnpesq.asp?id=txcotacao\&id=txcotacao $>$.Acesso em: 12 de setembro de 2014 .

Banco Central do Brasil. Crédito Rural. Disponível em: < http://www.bcb.gov.br/?credrural>. Acesso em: 18 de outubro de 2014.

Barbosa, H. M. J., Pauliquevis, T.,. Adams, D. K, Artaxo, P., Cirino, G. , Barja, B., Correia, A., Gomes, H., Gouveia, D. A., Padua, M. B., Rosario, N. M. E., Souza, R. A. F., Santos, R. M. N., Sapucci, L., Portela, B. T: ACONVEX-Aerosols, Clouds, cONvection, 
Experiment-A new site in central Amazonia for long term monitoring of aerosol-cloudsconvection interactions. In: AMS 95th Annual Meeting- Phoenix, Arizona, January 2015.

Barreto, P. A pecuária e o desmatamento na Amazônia na era das mudanças climáticas. Belém, PA: IMAZON, 2008.

Barreto, P.; Araújo, E.; Brito, B. A Impunidade de Crimes Ambientais em Áreas Protegidas Federais na Amazônia. Belém, PA: IMAZON, 2009.

Barreto, P. \& Silva, D. Como desenvolver a economia rural sem desmatar a Amazônia? Belém-PA: Imazon, 2013.

Barros, A. C.; Uhl, C. Padrões, Problemas e Potencial da Extração Madeireira ao Longo do Rio Amazonas e do seu Estuário in A Expansão Madeireira Na Amazônia: Impactos e Perspectivas Para o Desenvolvimento Sustentável no Pará. Belém-PA: Imazon, 2002.

Brando P.M, Nepstad D.C, Davidson E.A, Trumbore S.E, Ray D, Camargo P. Drought effects on litterfall, wood production, and belowground carbon cycling in an Amazon forest: results of a throughfall reduction experiment. Phil. Trans. R. Soc. B., v 363, p1839-1848, 2008.

Brando, P. M.; Balch, J. K.; Nepstad, D. C.; Morton, D. C.; Putz, F. E.; Coe, M. T.; Silverio, D.; Macedo, M. N.; Davidson, E. A.; Nobrega, C. C.; Alencar, A.; Soares-Filho, B. S. Abrupt increases in Amazonian tree mortality due to drought-fire interactions. Proceedings of the National Academy of Sciences, v. 111, n. 17, p. 6347-6352, 2014.

Brasil. Constituição da República Federativa do Brasil de 05 de outubro de 1988. Disponível em: <http://www.senado.gov.br/legislacao/const/con1988/CON1988_05.10.1988/>. Acesso em: 31 de julho de 2013.

Brasil. Lei 9.985, de 18 de julho de 2000. Regulamenta o art. 225, § 1o, incisos I, II, III e VII da Constituição Federal, institui o Sistema Nacional de Unidades de Conservação da Natureza e dá outras providências. Disponível em: < http://www.planalto.gov.br/ccivil_03/leis/19985.htm>. Acesso em: 15 de agosto de 2013.

Brasil. Lei no 11.284, de 2 de março de 2006. Dispõe sobre a gestão de florestas públicas para a produção sustentável; institui, na estrutura do Ministério do Meio Ambiente, o Serviço Florestal Brasileiro - SFB; cria o Fundo Nacional de Desenvolvimento Florestal - FNDF; altera as Leis nos 10.683, de 28 de maio de 2003, 5.868, de 12 de dezembro de 1972, 9.605, de 12 de fevereiro de 1998, 4.771, de 15 de setembro de 1965, 6.938, de 31 de agosto de 1981, e 6.015, de 31 de dezembro de 1973; e dá outras providências. Disponível em: < http://www.planalto.gov.br/ccivil_03/_ato2004-2006/2006/lei/111284.htm>. Acesso em: 24 de junho de 2013.

Brasil. Lei n. 12.187, de 29 de dezembro de 2009. Institui a Política Nacional sobre Mudança do Clima-PNMC e dá outras providências. Disponível em: <http://www.planalto.gov.br/ccivil_03/_Ato2007-2010/2009/Lei/L12187.htm>. Acesso em 17 de outubro de 2013.

Brasil. Decreto 7.390 de 9 de dezembro de 2010. Regulamenta os arts. 6o, 11 e 12 da Lei no 12.187, de 29 de dezembro de 2009, que institui a Política Nacional sobre Mudança do Clima - PNMC, e dá outras providências. Disponível em: 
<http://www.planalto.gov.br/ccivil_03/_Ato2007-2010/2010/Decreto/D7390.htm>. Acesso em 17 de outubro de 2013.

Brasil. Lei 12.651, 25 de maio de 2012. Dispõe sobre a proteção da vegetação nativa; altera as Leis nos 6.938, de 31 de agosto de 1981, 9.393, de 19 de dezembro de 1996, e 11.428, de 22 de dezembro de 2006; revoga as Leis nos 4.771, de 15 de setembro de 1965, e 7.754, de 14 de abril de 1989, e a Medida Provisória no 2.166-67, de 24 de agosto de 2001; e dá outras providências. Disponível em: < http://www.planalto.gov.br/ccivil_03/_ato20112014/2012/lei/112651.htm> Acesso em 13 de setembro de 2013.

Broadbent, E.; Asner, G.; Keller, M.; Knapp, D.; Oliveira, P.; Silva, J. Forest fragmentation and edge effects from deforestation and selective logging in the Brazilian Amazon. Biological Conservation, v. 141, n. 7, p. 1745-1757, 2008.

Carvalho, G.; Barros, A. C.; Moutinho, P., Nepstad, D. "Sensitive Development Could Protect Amazonia Instead of Destroying It". Nature, n. 409, p. 131, 2001.

Carvalho, R. M. Um Esudo da Geografia do Amazonas. 130p. Grafinorte: Manaus-AM. 2004. 1 edição.

Cavalett, O.; Ortega, E. Emergy, nutrients balance, and economic assessment of soybean production and industrialization in Brazil. Journal of Cleaner Production, v. 17, n. 8, p. 762$771,2009$.

Centro de Estudos Avançados em Economia Aplicada (CEPEA) - ESALQ/USP. Disponível em: <http://cepea.esalq.usp.br/indicador/> Acesso em: 14 de abril de 2014.

Chomitz, K. M.; Thomas, T. S. Determinants of Land Use in Amazonia: A Fine-Scale Spatial Analysis. American Journal of Agricultural Economics, v. 85, n. 4, p. 1016-1028, 2003.

Cox, P. M., Betts, R. A., Collins, M., Harris, P. P., Huntingford, C., Jones, C.D. Amazonian forest dieback under climate-carbon cycle projections for the 21st century. Theoretical and Applied Climatology. Austria: Springer-Verlag, 2004.

Davidson, E. A.; de Araújo, A. C.; Artaxo, P.; Balch, J. K.; Brown, I. F.; C. Bustamante; M. M.; Coe, M. T.; DeFries, R. S.; Keller, M.; Longo, M.; Munger, J. W.; Schroeder, W.; SoaresFilho, B. S.; Souza, C. M.; Wofsy, S. C. The Amazon Basin in Transition Nature, v. 481, n. 7381, p. 321-328, 2012.

DeFries, R.; Herold, M.; Verchot, L.; Macedo, M. N.; Shimabukuro, Y. Export-oriented deforestation in Mato Grosso: harbinger or exception for other tropical forests?. Philosophical Transactions of the Royal Society B: Biological Sciences, v. 368, n. 1619, p. 2012017320120173, 2013.

Eck, T. F.; Holben, B. N.; Reid, J. S.; O’Neill, N. T.; Schafer, J.; Dubovik, O.; Smirnov, A.; Yamasoe, M.A.; Artaxo, P. High aerosol optical depth biomass burning events: a comparison of optical properties for different source regions. Geophysical Research Letters, v 30, n 20, p 2.035-2.048, 2003. 
Fearnside, P. M.; Laurance, W F. O futuro da Amazônia: os impactos do Programa Avança Brasil. Ciência Hoje, v. 31, n. 182, p. 61-65, 2002.

Fearnside, P. M. A floresta amazônica nas mudanças globais. Manaus: INPA, 2003.

Fearnside, P. M. Deforestation in Brazilian Amazonia: History, Rates, and Consequences. Conservation Biology, v. 19, n 3, p. 680-688, 2005.

Fearnside, P. Desmatamento na Amazônia: dinâmica, impactos e controle. Acta Amazônica, v. 36, n. 3, p. 395-400, 2006.

Fearnside, P. Fatores Responsáveis pela Redução de Desmatamento na Amazônia Legal entre 2005 e 2013 [Julho de 2014]. Entrevista Concedida a Natália Mello.

Field, C. B., Behrenfeld, M. J., Randerson J. T., Falkowski, P. Primary Production of the Biosphere: Integrating Terrestrial and Oceanic Components. Science v. 281, n. 237, 1998.

Governo do Acre. Apresentação do Programa de Incentivo a Serviços Ambientais. Disponível em: < http://www.ac.gov.br/ >. Acesso em: 14 de maio de 2013.

Guyon, P.; Graham, B.; Roberts, G. C.; Mayol-Bracero, O. L.; Maenhaut, W.; Artaxo, P.; Andreae, M. O. Sources of optically active aerosol particles over the Amazon forest. Atmospheric Environment, v 38, n 7, p 1.039-1.05, 2004.

Hecht, Susanna B. From eco-catastrophe to zero deforestation? Interdisciplinarities, politics, environmentalisms and reduced clearing in Amazonia. Envir. Conserv., v. 39, n. 01, p. 4-19, 2011.

Herold, M., Román-Cuesta, R., Mollicone, D., Hirata, Y., Van Laake, P., Asner, G. P., Souza, C., Skutsch, M., Avitabile, V. e MacDicken, K. Options for monitoring and estimating historical carbon emissions from forest degradation in the context of REDD+. Carbon Balance and Management, v. 6, n. 1, p. 13, 2011.

Instituto Brasileiro de Geografia e Estatística. Séries Estatísticas. Disponível em: < http://seriesestatisticas.ibge.gov.br/>. Acesso em: 20 de outubro de 2014.

Instituto do Homem e Meio Ambiente da Amazônia. Fatos Florestais. Disponível em: $<$ http://site1378233601.provisorio.ws/visualize-aqui-a-versao-online-da-publicacao/>. Acesso em 15 de novembro de 2014.

Instituto Nacional de Meteorologia. Dados Históricos. Disponível em: < http://www2.ana.gov.br/Paginas/servicos/informacoeshidrologicas/redehidro.aspx >. Acesso em 23 de outubro de 2014.

Instituto Nacional de Pesquisas Espaciais. Monitoramento de Queimadas. Disponível em: <http://www.inpe.br/queimadas/>. Último Acesso em: 19 de dezembro de 2014.

Instituto Nacional de Pesquisas Espaciais. Sistema DETER. Disponível em: <http://www.obt.inpe.br/deter/>. Último Acesso em: 19 de dezembro de 2014. 
Instituto Nacional de Pesquisas Espaciais. Sistema DEGRAD. Disponível em: <http://www.obt.inpe.br/degrad/> . Último Acesso em: 19 de dezembro de 2014.

Instituto Nacional de Pesquisas Espaciais. Sistema PRODES. Disponível em: <http://www.obt.inpe.br/prodes/>.. Último Acesso em: 19 de dezembro de 2014.

IPAM; IMAZON; ISA. Aumento no Desmatamento na Amazônia em 2013: um ponto fora da curva ou fora de controle?. Belém, PA, 2013.

Instituto de Pesquisa Ambiental da Amazônia. Cadastro Ambiental Rural (CAR): Implementação e Transparência. Disponível em: <http://www.ipam.org.br/noticias/CadastroAmbiental-Rural-CAR-Implementacao-e-transparencia/3186>. Acesso em: 20 de outubro de 2014.

IPCC 2007 INTERGOVERNMENTAL PANEL ON CLIMATE CHANGE (IPCC): Summary for Policymakers. In: Climate Change 2007 Mitigation. Contribution of Working Group III to the Fourth Assessment Report of the Intergovernmental Panel on Climate Change [B. Metz, O.R. Davidson, P.R. Bosch, R. Dave, L.A. Meyer (eds)], Cambridge University Press, Cambridge, United Kingdom and New York, NY, USA, 2007.

IPEA; GIZ; CEPAL. Avaliação do Plano de Ação para Prevenção e Controle do Desmatamento na Amazônia Legal: PPCDAm 2007-2010. Brasília: IPEA; GIZ; CEPAL, 2011.

Kaufman, Y.; Hobbs, P. V.; Kirchhoff, V.W. J. H.; Artaxo, P.; Remer, L.; Holben, B.N.; King, M. D.; Prins, E. M.; Ward, D. E.; Longo, K. M.; Mattos, L. F.; Nobre, C. A.; Spinhirne, J.; Thompson, A. M.; Gleason, J. F.; Christopher, S. A. The Smoke Cloud and Radiation Experiment in Brazil (SCAR-B). Journal of Geophysical Research, v. 10, D24, p. 31.78331.808, 1998.

KPMG. A roadmap to responsible soy. Disponível em $<$ http://www.kpmg.com/Global/en/IssuesAndInsights/ArticlesPublications/sustainable-insight /Pages/roadmap-responsible-soy.aspx> Acesso em 10 de junho de 2013.

Laurance, W. F. Deforestation in Amazonia. Science, v. 304, n. 5674, p. 1109b-1111b, 2004.

Laurance, W. F. Environment: The Future of the Brazilian Amazon. Science, v. 291, n. 5503, p. 438-439, 2001.

Laurance, W. F., Camargo, J. L., Luizão, R. C., Laurance, S. G., Pimm, S. L., Bruna, E. M., Stouffer, P. C., Bruce Williamson, G., Benítez-Malvido, J. e Vasconcelos, H. L. The fate of Amazonian forest fragments: A 32-year investigation. Biological Conservation, v. 144, n. 1, p. 56-67, 2011.

Lima, L.A.F.; Margarido, M.A. Causas do atual ciclo de alta de preços de commodities. Análises e Indicadores do Agronegócio, São Paulo, v. 3, n. 7, 2008.

Lima, A.; Capobianco, J P R; Moutinho, P. Desmatamento na Amazônia: Medidas e efeitos do Decreto Federal 6.321/07. IPAM, 2009. 
Lima, A., Silva, T. S. F., Aragão, L. E. O. E. C. D., Feitas, R. M. D., Adami, M., Formaggio, A. R. e Shimabukuro, Y. E. Land use and land cover changes determine the spatial relationship between fire and deforestation in the Brazilian Amazon. Applied Geography, v. 34, p. 239-246, 2012.

Liousse, C.; Cachier, H.; Grégoire, J.M.; Penner, J.; Lavoué, D.; Hobbs, P.; Scholes, M.; Barbosa, P.; Andreae M. O.; Artaxo, P.. Deriving global quantitative estimates for spatial and temporal distributions of biomass burning emissions. In: Granier, C.; Artaxo, P.; Reeves, C. (eds). Emissions of trace gases and aerosols into the atmosphere. London: Kluwer Academic Publishers, 2004.

Loureiro, V.R. \& Aragão, J.N. A questão fundiária na Amazônia. Estudos Avançados 9 (1): 81-88, 2005.

Malhi, Y., Wood, D., Bakers, T. R., Wright, J., Philips, O. L., Cochrane, T. et al. The regional variation of aboveground live biomass in old-growth Amazonian forests. Global Change Biology, v. 12, p. 1107-1138, 2006.

Malhi, Y., Roberts, J. T., Betts, R. A., Killeen, T. J., Li, W. e Nobre, C. A. Climate Change, Deforestation, and the Fate of the Amazon. Science, v. 319, n. 5860, p. 169-172, 2008.

Marcovitch, Jacques (Org.). Fundo Amazônia: Uma Experiência de Cooperação Internacional e Gestão Brasileira. São Paulo: FEA/USP, 2013. Disponível em: <http://www.usp.br/mudarfuturo/cms>. Acesso em: 26 de agosto de 2014.

Margulis, Sergio. Causas do Desmatamento na Amazônia Brasileira. Brasília: Banco Central, 2003.

Martins, H., Araújo, E., Vedoveto, M., Monteiro, D. e Barreto, P. Desmatamento em Áreas Protegidas Reduzidas na Amazônia. IMAZON, 2014.

Ministério do Meio Ambiente e Serviço Florestal Brasileiro. Florestas do Brasil em Resumo (Relatório). Brasília, DF, 2013.

Ministério da Ciência e Tecnologia e Instituto Nacional de Pesquisas Espaciais. Monitoramento da cobertura florestal da Amazônia por satélites. Sistemas PRODES, DETER, DEGRAD E QUEIMADAS 2007-2008. São José dos Campos, SP, 2008.

Moran, Emilio F. Deforestation and land use in the Brazilian Amazon. Human Ecology, v. 21, n. 1, p. 1-21, 1993.

Morton, D.C.; Sales, M.H.; Souza, C.M.; Griscom, B. Historic emissions from deforestation and forest degradation in Mato Grosso, Brail: 1) source data uncertainties. Carbon Balance and Management, 6:18, 2011.

Moutinho, M. Fatores Responsáveis pela Redução de Desmatamento na Amazônia Legal entre 2005 e 2013 [Julho de 2014]. Entrevista Concedida a Natália Mello.

Nepstad, D., Carvalho, G., Cristina Barros, A., Alencar, A., Paulo Capobianco, J., Bishop, J., Moutinho, P., Lefebvre, P., Lopes Silva, U. e Prins, E. Road paving, fire regime feedbacks, 
and the future of Amazon forests. Forest Ecology and Management, v. 154, n. 3, p. 395-407, 2001.

Nepstad, D., Azevedo-Ramos, C., Lima, E., Mcgrath, D., Pereira, C. E Merry, F. Managing the Amazon Timber Industry. Conservation Biology, v.Â 18, n.Â 2, p.Â 575-577, 2004.

Nepstad, D.; Stickler, C.; Almeida, O. Globalization of the Amazon Soy and Beef Industries: Opportunities for Conservation. Conservation Biology, v.ÂA 20, n.ÂA 6, p.ÂA 1595-1603, 2006.

Nepstad, D. C., Stickler, C. M., Filho, B. S. e Merry, F. Interactions among Amazon land use, forests and climate: prospects for a near-term forest tipping point. Philosophical Transactions of the Royal Society B: Biological Sciences, v. 363, n. 1498, p. 1737-1746, 2008.

Nepstad, D., McGrath, D., Stickler, C., Alencar, A., Azevedo, A., Swette, B., Bezerra, T., DiGiano, M., Shimada, J., Seroa da Motta, R., Armijo, E., Castello, L., Brando, P., Hansen, M. C., McGrath-Horn, M., Carvalho, O. e Hess, L. Slowing Amazon deforestation through public policy and interventions in beef and soy supply chains. Science, v. 344, n. 6188, p. 1118-1123, 2014.

Orlando, J. P. Estudo dos Percursores de Ozônio. Mestrado, Universidade de São Paulo Instituto de Pesquisas Enérgicas e Nucleares, 2008.

Oyama, M.D.; Nobre, C.A.. A new climate-vegetation equilibrium state for Tropical South America. Geophysical Research Letters, v. 30, n. 23, p. 2199-2203, 2003.

Pinto, E.; Moutinho, P.; Rodrigues, L.; Oyo, F. G.; Moreira, P. F.; Dietzsch, L. Cartilha: Perguntas e Respostas Sobre Aquecimento Global. 4a edição. Instituto de Pesquisa Ambiental da Amazônia. Belém, 2009.

Plano de ação para prevenção e controle do desmatamento da Amazônia Legal (PPCDAm) Fase I. Brasília, DF: Casa Civil, 2004.

Plano de ação para prevenção e controle do desmatamento da Amazônia Legal (PPCDAm) Fase II. Brasília, DF: Casa Civil, 2009.

Plano de ação para prevenção e controle do desmatamento da Amazônia Legal (PPCDAm) Fase III. Brasília, DF: Casa Civil, 2012.

Portal Brasil. Conheça o passo a passo para efetuar o Cadastro Ambiental Rural. Disponível em: <http://www.brasil.gov.br/meio-ambiente/2014/05/conheca-o-passo-a-passo-para-efetuaro-cadastro-ambiental-rural>. Acesso em: 17 de junho de 2014.

Prates, Rodolfo Coelho. Desmatamento na Amazônia: dinâmica, impactos e controle. Doutor, Universidade de São Paulo - Escola Superior de Agricultura "Luiz de Queiroz", 2008.

Programa Municípios Verdes. Disponível em: <http://municipiosverdes.com.br/>. Acesso em: 14 de julho de 2013. 
RAISG - Rede Amazônica de Informação Socioambiental Georreferenciada. Amazônia sob Pressão. São Paulo: Instituto Socioambiental, 2012.

Rajao, R.; Vurdubakis, T. On the Pragmatics of Inscription: Detecting Deforestation in the Brazilian Amazon. Theory, Culture \& Society, v. 30, n. 4, p. 151-177, 2013.

Rajão, R. Fatores Responsáveis pela Redução de Desmatamento na Amazônia Legal entre 2005 e 2013 [Julho de 2014]. Entrevista Concedida a Natália Mello.

Rautner, M.; Leggett, M.; Davis, F. The Little Book of Big Deforestation Drivers, Global Canopy Programme: Oxford, 2013.

Ray D, Nepstad D, Moutinho P. Micrometeorological and canopy controls of fire susceptibility in forested Amazon landscape. Ecol. Appl. v 15, p 1664-1678, 2005.

Rivero, S., Almeida, O., Ávila, S. e Oliveira, W. Pecuária e desmatamento: uma análise das principais causas diretas do desmatamento na Amazônia. Nova Economia, v. 19, n. 1, p. 4166, 2009.

Rosolen, D., Araújo, M. V., Lyrio, M. Previsão dos preços de commodities por meio das taxas de câmbio. Estud. Econ. v.43, n.4, 2013

Ruviaro, C. F., Barcellos, J. O. J. e Dewes, H. Market-oriented cattle traceability in the Brazilian Legal Amazon. Land Use Policy, v. 38, p. 104-110, 2013.

Serviço Florestal Brasileiro e Instituto do Homem e Meio Ambiente da Amazônia. A atividade madeireira na Amazônia brasileira: produção, receita e mercados (Relatório). Belém, PA, 2003.

Serviço Florestal Brasileiro e Instituto do Homem e Meio Ambiente da Amazônia. A atividade madeireira na Amazônia brasileira: produção, receita e mercados (Relatório). Belém, PA, 2005.

Serviço Florestal Brasileiro e Instituto do Homem e Meio Ambiente da Amazônia. A atividade madeireira na Amazônia brasileira: produção, receita e mercados (Relatório). Belém, PA, 2010.

Serviço Florestal Brasileiro e Instituto de Pesquisa Ambiental da Amazônia. Florestas Nativas de Produção Brasileiras. (Relatório). Brasília, DF, 2011.

Serviço Florestal Brasileiro. Gestão de Florestas Públicas (Relatório). Brasília, DF, 2013.

Serviço Florestal Brasileiro. Sistema Nacional de Informações Florestais. Disponível em: <http://www.florestal.gov.br/snif/>. Acesso em: 12 de maio de 2013.

Serviço Florestal Brasileiro. Programa Federal de Manejo Florestal Comunitário e Familiar. Disponível em: <http://www.florestal.gov.br/florestas-comunitarias/programa-federal-demanejo-florestal-comunitario-e-familiar/programa-federal-de-manejo-florestal-comunitario-efamiliar>. Acesso em: 17 de junho de 2013. 
Serviço Florestal Brasileiro. Concessão Florestal - Um novo paradigma de uso das florestas. Disponível em: <http://www.florestal.gov.br/concessoes-florestais/o-que-e-concessaoflorestal/concessao-florestal-um-novo-paradigma-de-uso-das-florestas $>$. Acesso em: 20 de junho de 2013.

Setzer, A.; Moreli, F. Occurrences of Vegetation Fires in the Protected Areas of the Brazilian Amazonia Protected Areas of the Brazilian Amazonia. INPE, 2008. Disponível em: $<$ http://queimadas.cptec.inpe.br/ rqueimadas/documentos/2008_Setzer_Morelli_fogoUCs_L BA_IVConf.pdf $>$ Acesso em: 07 de agosto de 2014.

Setzer, A. W.; Jesus, S. C.; Morelli, F.; Maruano, L. E. A Case of Illegal Clearing in Amazonia Anticipated by The Detection of Fires and Forest Degradation. Instituto Nacional de Pesquisas Espaciais-INPE, 2011.

Setzer, A. Fatores Responsáveis pela Redução de Desmatamento na Amazônia Legal entre 2005 e 2013 [Julho de 2014]. Entrevista Concedida a Natália Mello.

Soares-Filho, B. S.; Nepstad, D.C.; Curran, L.M.; Cerqueira, G.C.; Garcia, R.A.; Ramos, C.A.; Voll, E.; McDonald, A.; Lefebvre,P.; Schlesinger, P. Modelling conservation in the Amazon basin. Nature 440, p. 520- 523, 2006.

Soares-Filho, et al. Uso da Terra, Mudança de Uso da Terra e Florestas. Estudo de Baixo Carbono para o Brasil, Banco Mundial: 2010a.

Soares-Filho, B., Moutinho, P., Nepstad, D., Anderson, A., Rodrigues, H., Garcia, R., Dietzsch, L., Merry, F., Bowman, M., Hissa, L., Silvestrini, R. e Maretti, C. Role of Brazilian Amazon protected areas in climate change mitigation. Proceedings of the National Academy of Sciences, v. 107, n. 24, p. 10821-10826, 2010 b.

Soares-Filho, B. Fatores Responsáveis pela Redução de Desmatamento na Amazônia Legal entre 2005 e 2013 [Julho de 2014]. Entrevista Concedida a Natália Mello.

Souza Jr., C., Brandão Jr., A., Veríssimo, A., \& Anderson, A. Avanço das estradas endógenas na Amazônia (No. 1) (p.2). Belém: Imazon, 2005.

Souza, R. A.; Miziara, F.; De Marco Junior, P. Spatial variation of deforestation rates in the Brazilian Amazon: A complex theater for agrarian technology, agrarian structure and governance by surveillance. Land Use Policy, v. 30, n. 1, p. 915-924, 2013.

Tundisi, J. G. The exploitation of the hydroelectrical potential of the Amazon region. Estudos Avançados v. 21, n. 59, 2007.

Valeriano, D. Fatores Responsáveis pela Redução de Desmatamento na Amazônia Legal entre 2005 e 2013 [Julho de 2014]. Entrevista Concedida a Natália Mello.

Verburg, R., Filho, S. R., Lindoso, D., Debortoli, N., Litre, G. e Bursztyn, M. The impact of commodity price and conservation policy scenarios on deforestation and agricultural land use in a frontier area within the Amazon. Land Use Policy, v. 37, p. 14-26, 2014. 
Veríssimo, A., Rolla, A., Vedoveto, M. e Futada, S. M. Áreas protegidas na amazônia brasileira avanços e desafios. IMAZON/ISA, 2011.

Villela, A. A., Jaccoud, D. B., Rosa, L. P. e Freitas, M. V. Status and prospects of oil palm in the Brazilian Amazon. Biomass and Bioenergy, v. 67, p. 270-278, 2014.

Waldhoff, P.; Vidal, E. Community loggers attempting to legalize traditional timber harvesting in the Brazilian Amazon: An endless path. Forest Policy and Economics, v. 50, p. 311-318, 2014.

Werth D.; Avissar, R. The local and global effects of Amazon deforestation. J. Geophys Res.v 107, n 8087, 2002.

Worldwatch Institute. In Brazil, Violence Looms at the Forest Edge. Disponível em: <http://www.worldwatch.org/node/5697>. Acesso em: 20 de junho de 2013. 